\title{
ipen
}

AUTARQUIA ASSOCIADA À UNIVERSIDADE DE SÃO PAULO

\section{CARACTERIZAÇÃO BIOQUÍMICA E FARMACOLÓGICA DA CROTAMINA IRRADIADA POR RAIOS GAMA DE Co-60}

\author{
Karina Corleto de Oliveira
}

Tese apresentada como parte dos requisitos para obtenção do Grau de Doutor em Ciências na Área de Tecnologia Nuclear - Aplicações

Orientadora:

Profa. Dra. Nanci do Nascimento 
INSTITUTO DE PESQUISAS ENERGÉTICAS E NUCLEARES

Autarquia associada à Universidade de São Paulo

\title{
CARACTERIZAÇÃO BIOQUÍMICA E FARMACOLÓGICA DA CROTAMINA IRRADIADA POR RAIOS GAMA DE Co-60
}

Karina Corleto de Oliveira

\begin{abstract}
Tese apresentada como parte dos requisitos para obtenção do Grau de Doutor em Ciências na Área de Tecnologia Nuclear - Aplicações

Orientadora:

Profa. Dra. Nanci do Nascimento
\end{abstract}

Versão Corrigida

$\#$ 
Dedico este trabalho àqueles que trago no coração desde sempre e aqui sempre estarãó: meus pais, Antonio e Osonia, e meu irmão Danilo 


\section{AGRADECIMENTOS}

Inicialmente a Deus, pois é pelo Seu amor que todos estamos aqui.

À Dra. Nanci do Nascimento, minha orientadora, que novamente me acompanhou e orientou nessa etapa, muito obrigada pelo apoio em todos os momentos.

Ao Dr. Patrick Jack Spencer pela ajuda constante e por me acolher como sua aluna em vários momentos.

Às Dras. Maria Teresa C. Ribela e Regina Affonso pelas considerações no Seminário de Área e em demais momentos durante o desenvolvimento do trabalho.

Aos demais pesquisadores e funcionários do Centro de Biotecnologia do IPEN pela atenção e colaboração em inúmeros momentos, em especial ao João Ezequiel Oliveira, mais conhecido como Johnny.

Ao Dr. Rui S. Ferreira Júnior, do Centro de Vacinas e Animais Peçonhentos (CEVAP), por toda sua colaboração em fornecer o material para este estudo.

À Dra. Lígia E. M. F. Dias, do IPEN, que autorizou em alguns momentos o uso do seu equipamento de alta pressão hidrostática.

À Dr. Maria Cecília Salvadori, do Instituto de Física da USP, pelas análises de Microscopia de Força Atômica.

Ao Dr. Daniel C. Pimenta, do Instituto Butantan, pelas análises de Espectrometria de Massa. 
Aos amigos "irmãos" do grupo do Dr. Patrick, pela amizade e ajuda constante, em especial à Tamara Mieco Fucase e ao Vincent Louis Viala pelo carinho.

Às amigas que sempre me ajudaram em todos os aspectos. Muito obrigada por todo o carinho Larissa Miranda Pereira, Natália Malavasi Vallejo e Danielle Rodrigues Borim. Tenho orgulho por ter encontrado vocês na minha vida.

Às demais amigas, que embora não estejam mais no IPEN, fizeram parte de toda essa história e sempre estiveram ao meu lado: Keli Balduíno, Renata Damiani, Beatriz Almeida, Taís Oliveira.

Ao grupo de Modo de Ação de Drogas do Instituto Butantan pela imensurável ajuda nos ensaios farmacológicos, especialmente ao Dr. Isaltino Marcelo Conceição e à Thalma Ariani Freitas.

Ao Dr. Cláudio Fontes Souza por todos os seus ensinamentos na área de farmacologia e pela constante ajuda nessa etapa final.

Ao amigo Dr. Rogrigo Godines por todos os momentos de risada e pela ajuda com os experimentos de Fluorescência.

À Mariana El Corab pelo companheirismo nos experimentos com animais e nas cromatografias.

Às amigas Arlete Correia, Rute Batista e Neide Mascarenhas por todos os momentos de risada e auxílio nesses sete anos de IPEN.

A todos os funcionários do centro pelo cuidado com a limpeza das salas e laboratórios. 
Aos integrantes da Comissão de Pós-Graduação pela ajuda em momentos burocráticos e pelos momentos de ensinamento nas reuniões da CPG.

À CAPES pelo apoio financeiro.

A todos que, direta ou indiretamente, colaboraram no desenvolvimento deste trabalho.

À minha querida família que sempre esteve do meu lado, nos momentos felizes e nos momentos tristes e é a minha base para toda a vida..

Ao Rafael Tarantino que conquistou o meu amor e desde então faz da minha vida um lugar mais gostoso para se viver... 
Asó há duas maneiras de viver a vida: a primeira é vivếla como se os milagres não existissem. Al segunda é vivé-la como se tudo fosse milagre.

Albert Q Einstein 


\title{
CARACTERIZAÇÃO BIOQUÍMICA E FARMACOLÓGICA DA CROTAMINA IRRADIADA POR RAIOS GAMA DE Co-60
}

\author{
Karina Corleto de Oliveira
}

\section{RESUMO}

A produção de soro no Brasil, único tratamento eficaz nos casos de acidentes ofídicos, utiliza equinos que apesar do grande porte, apresentam diminuição da longevidade quando comparado com os cavalos não imunizados. A radiação ionizante tem se mostrado como excelente ferramenta na diminuição da toxicidade de venenos e toxinas isoladas, além de promover a obtenção de melhores imunógenos para a produção de soro. Sabe-se, contudo, que os efeitos da radiação ionizante em materiais protéicos caracterizam-se por diversas alterações químicas, como fragmentação, "crosslinking", agregação e oxidação devido aos produtos gerados pela radiólise da água. Porém, a ação da radiação gama em toxinas ainda não está totalmente esclarecida do ponto de vista estrutural e farmacológico, fato que impede a aplicação de tal metodologia no processo de produção do soro. Assim, foi proposto nesse trabalho a caracterização da crotamina, uma das principais proteínas do veneno da espécie Crotalus durissus terrificus, irradiada com raios gama de ${ }^{60} \mathrm{Co}$. Após o isolamento da toxina por técnicas cromatográficas e a realização de testes para comprovar a obtenção da crotamina pura, a toxina, nos estados nativo e irradiado, foi submetida às análises estruturais de Fluorescência e Dicroísmo Circular. Testes utilizando altas pressões hidrostáticas também foram realizados com o intuito de verificar se as alterações conformacionais causadas pela radiação sofreriam modificações sob altas pressões. Do ponto de vista farmacológico, testes de contração muscular foram realizados com o objetivo de delimitar a ação da crotamina em musculatura lisa, bem como a mudança na ação da toxina frente às alterações estruturais ocasionadas. As análises de Fluorescência e Dicroísmo Circular mostraram que há mudanças na conformação da crotamina quando submetida à radiação gama e que tais alterações possivelmente ocorrem na estrutura terciária e secundária da proteína. O observado nos testes farmacológicos 
mostraram que a crotamina irradiada foi menos eficaz na diminuição da contração muscular do ducto deferente de ratos em comparação com a crotamina nativa. Além disso, o comportamento da toxina irradiada na contração tônica, modulada por noradrenalina, foi distinto daquele observado para a toxina nativa. 


\title{
BIOCHEMICAL AND PHARMACOLOGICAL CHARACTERIZATION OF IRRADIATED CROTAMINE BY GAMMA RAYS $\mathrm{Co}^{60}$
}

\author{
Karina Corleto de Oliveira
}

\begin{abstract}
The serum production in Brazil, the only effective treatment in cases of snakebites, uses horses that although large size, have reduced llifespan compared with horses not immunized. Ionizing radiation has been shown as an excellent tool in reducing the toxicity of venoms and toxins isolated, and promote the achievement of better immunogens for serum production, and contributing to the welfare of serum-producing animals. It is known, however, that the effects of ionizing radiation on protein are characterized by various chemical modifications, such as fragmentation, cross-linking due to aggregation and oxidation products generated by water radiolysis. However, the action of gamma radiation on toxins is not yet fully understood structurally and pharmacologically, a fact that prevents the application of this methodology in the serum production process. So we proposed in this paper the characterization of crotamine, an important protein from the venom of Crotalus durissus terrificus species, irradiated with ${ }^{60} \mathrm{Co}$ gamma rays. After isolating the toxin by chromatographic techniques and testing to prove the obtaining of pure crotamine, it was irradiated with gamma rays and subjected to structural analysis, Fluorescence and Circular Dichroism. Using high hydrostatic pressure tests were also conducted in order to verify that the conformational changes caused by radiation suffer modifications under high pressures. From the pharmacological point of view, muscle contraction tests were conducted with the objective of limiting the action of crotamine in smooth muscle as well as the change in the action of toxin caused structural changes to the front. Analysis of Circular Dichroism and Fluorescence showed changes in structural conformation of crotamine when subjected to gamma radiation and that such changes possibly occurring in the secondary and tertiary structure of the protein. The observed in pharmacological tests showed that the irradiated crotamine was less effective in lowering the vas deferens twitch in rats in
\end{abstract}


comparison to native crotamine. In addition, the behavior of irradiated toxin in tonic contraction, modulated by noradrenaline, was different from that observed for the native toxin. 


\section{SUMÁRIO}

\section{INTRODUÇÃO}

Páginas

1.1 Acidentes ofídicos

18

1.20 veneno crotálico e seus componentes …............................ 21

1.2.1 Aspectos estruturais da crotamina .................................... 25

1.2.2 Aspectos farmacológicos da crotamina ............................. 28

1.2.3 Demais atividades da crotamina .................................. $\quad 30$

1.3 Soroterapia e a radiação ionizante .................................... 32

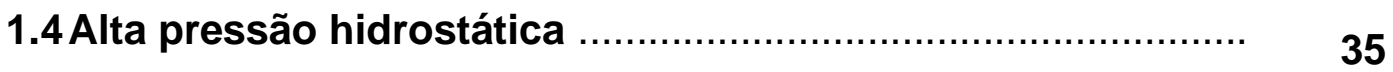

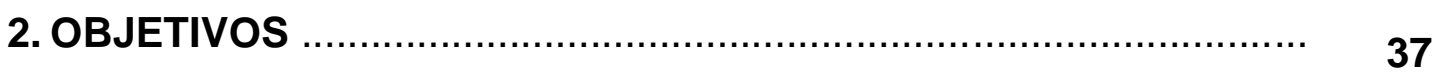

3. MATERIAL E MÉTODOS …….............................................. 38

$\mathbf{3} .1$ Isolamento das toxinas ……......................................... 39

3.1.1 Cromatografia de exclusão molecular ………………......... 39

3.1.2 Cromatografia de troca iônica ………………………........ 39

3.1.3 Cromatografia de exclusão molecular de alta eficiência (HPSEC)

3.1.4 Protocolo de fracionamento da crotamina proveniente do CEVAP

3.1.5 Cromatografia de fase reversa (RP-HPLC)

3.2 Dosagem protéica

3.3 Liofilização

3.4 Irradiação das proteínas

3.5 Eletroforese em gel de poliacrilamida (SDS-PAGE)

3.6 Espectrometria de massa

3.7 Análise de Fluorescência 
3.9 Microscopia de Força Atômica

3.10 Teste de desnaturação …………………………......... 49

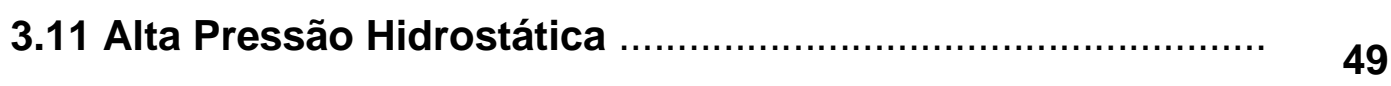

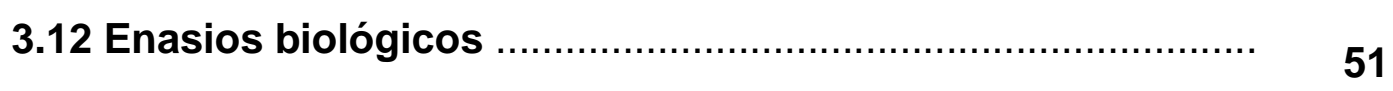

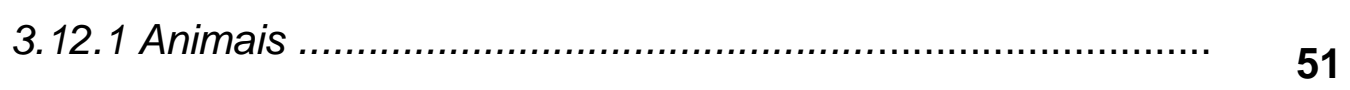

3.12.2 Experimentos de contração muscular "in vitro".................... 51

3.12.2.1 Isolamento dos ductos deferentes ............................. 51

3.12.2.2 Solução nutritiva ..................................................... 52

3.12.3 Aparelhagem e montagem da preparação ........................ 52

3.12.4 Estudo da capacidade de liberação de neurotransmissores.

3.12.4.1 Contrações isométricas induzidas por estimulação elétrica

3.13 Análises Estatísiticas

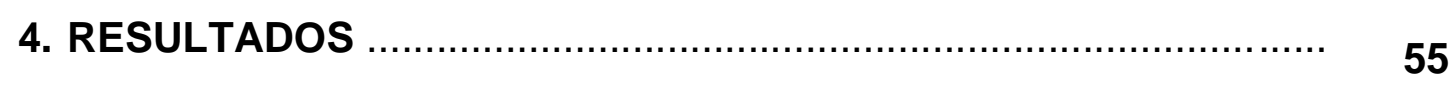

4.1 Isolamento da crotamina ….......................................... 55

4.2 Eletroforese em gel de poliacrilamida (SDS-PAGE)................ 61

4.3 Espectrometria de massa ............................................. 62

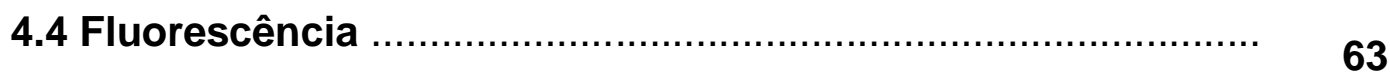

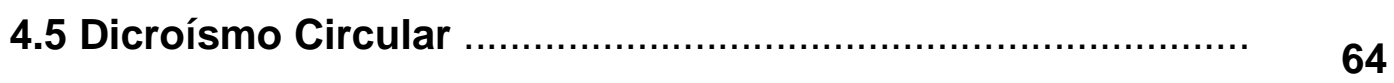

4.6 Microscopia de Força Atômica ......................................... 66

4.7 Alta Pressão Hidrostática ……......................................... 69

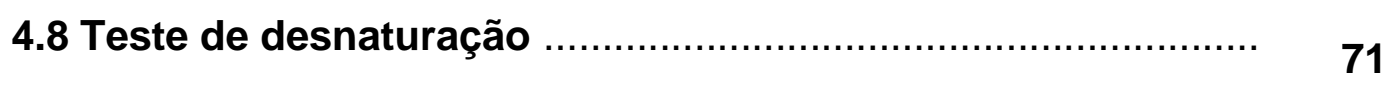

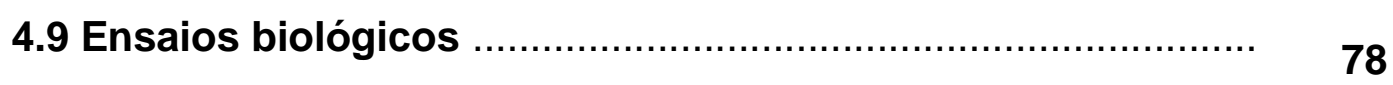

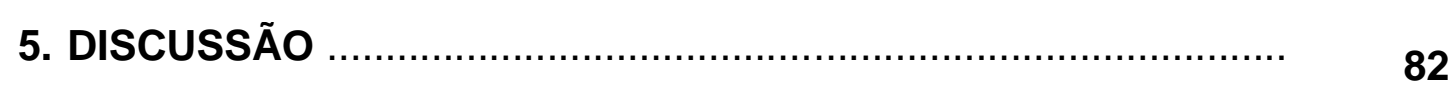

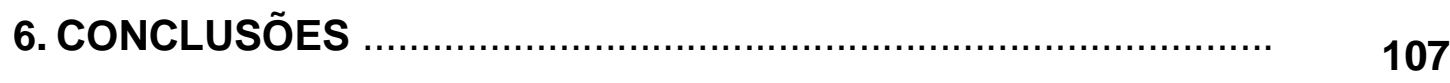

REFERÊNCIAS BIBLIOGRÁFICAS ............................................. 109 


\section{LISTA DE FIGURAS}

Páginas

Figura 1 Porcentagem de acidentes ofídicos por gênero de acordo com o 20 Ministério da Saúde (2008).

Figura 2 Distribuição da espécie Crotalus durissus no território brasileiro. 22

Figura $3 \quad$ Serpente da espécie Crotalus durissus terrificus 22

Figura 4 Sequência primária da crotamina com indicação das pontes 24 dissulfeto.

$\begin{array}{lll}\text { Figura } 5 & \text { Estrutura tridimensional da crotamina resolvida por RMN. }\end{array}$

Figura 6 Conformação estrutural da crotamina. Em amarelo estão as 27 pontes dissulfeto

Figura 7 Distribuição da superfície de cargas na estrutura da crotamina em duas dimensões.

Figura 8 Efeito da crotamina nos membros posteriores quando injetada de forma intraperitoneal.

Figura 9 Esquema representativo da análise por espectrometria de 45 massa.

Figura 10 Gráfico da Força x Distância de separação ponta-amostra, onde são ilustradas as regiões características dos diferentes modo de análise em Microscopia de Força Atômica.

Figura 11 Registro típico da contração do ducto deferente de rato, induzida pelo cloreto de bário e pela estimulação elétrica em frequências crescentes entre 0,05 a $20,0 \mathrm{~Hz}(50 \mathrm{~V}, 3,0 \mathrm{~ms})$.

Figura 12 Cromatograma do veneno total da C.d.terrificus em coluna de exclusão molecular Superdex 75 10/300 GL. O tampão formiato de amônio, 200 mM, pH 3,0 foi utilizado para a eluição das frações.

Figura 13 Recromatografia da crotamina em coluna de troca catiônica (Mono S). Utilizou-se tampão fosfato de sódio, $50 \mathrm{mM}, \mathrm{pH} 7,8$. O gradiente linear de $\mathrm{NaCl}$ variou de 0 a $2 \mathrm{M}$.

Figura 14 Gel filtração analítica da fração correspondente à crotamina 58 oriunda da primeira etapa de fracionamento.

Figura 15 Gel filtração analítica da fração correspondente à crotamina após a segunda etapa de isolamento.

48

54

56

Figura 16 Gel filtração analítica da fração correspondente à crotamina após o processo de irradiação. 
Figura 17 Cromatografia de fase reversa (RP-HPLC) comparativa em coluna Vydac C-8 realizada para verificação da crotamina cedida pelo CEVAP.

Figura 18 Gel de eletroforese (15\%) corado com Coomassie blue 250-R. 62

Figura 19 Espectrometria de massa da crotamina nativa em um 62 instrumento IT-TOF.

Figura 20 Espectrometria de massa da crotamina irradiada em um 63 instrumento IT-TOF.

Figura 21 Espectro de fluorescência do triptofano presente na crotamina nativa e irradiada, ambas na concentração de $100 \mu \mathrm{g} / \mathrm{mL}$ em tampão PBS.

Figura 22 Análise de Dicroísmo Circular da crotamina nativa e irradiada, ambas na concentração de $100 \mu \mathrm{g} / \mathrm{mL}$ em tampão PBS.

Figura 23 Análise de Dicroísmo Circular, em diferentes temperaturas, da 65 crotamina nativa e irradiada, ambas na concentração de 100 $\mu \mathrm{g} / \mathrm{mL}$ em tampão PBS.

Figura 24 Análise de Dicroísmo Circular da crotamina nativa e irradiada, ambas na concentração de $100 \mu \mathrm{g} / \mathrm{mL}$ em tampão PBS.

Figura 25 Imagem obtida pela técnica de Tapping Mode, de uma amostra em solução da crotamina nativa, em concentração de $0,1 \mu \mathrm{g} / \mathrm{mL}$, adsorvida em superfície de mica.

Figura 26 Imagem em 3D representativa da crotamina nativa na concentração de $0,1 \mu \mathrm{g} / \mathrm{mL}$.

Figura 27 Imagem obtida pela técnica de Tapping Mode, de uma amostra em solução da crotamina irradiada, em concentração de 0,1 $\mu \mathrm{g} / \mathrm{mL}$, adsorvida em superfície de mica.

Figura 28 Imagem em 3D da amostra de crotamina irradiada, na concentração de $0,1 \mu \mathrm{g} / \mathrm{mL}$.

Figura 29 Análise de alta pressão hidrostática, com variação decrescente, 70 da crotamina nativa e irradiada, ambas na concentração de 20 $\mu \mathrm{g} / \mathrm{mL}$ em tampão TRIS.

Figura 30 Análise de alta pressão hidrostática da crotamina irradiada na concentração de $20 \mu \mathrm{g} / \mathrm{mL}$ em tampão TRIS. Perfil correspondente à leitura de fluorescência em decorrência da variação crescente de pressão para a crotamina irradiada.

Figura 31 Espectro de fluorescência do triptofano presente na crotamina nativa $(\mathbf{A})$ e irradiada (B) em 0,5 M de guanidina.

Figura 32 Espectro de fluorescência do triptofano presente na crotamina 72 nativa $(\mathbf{A})$ e irradiada (B) em 1,0 M de guanidina. 
Figura 33 Espectro de fluorescência do triptofano presente na crotamina nativa $(\mathbf{A})$ e irradiada $(\mathbf{B})$ em 1,5 $\mathrm{M}$ de guanidina.

Figura 34 Espectro de fluorescência do triptofano presente na crotamina 73 nativa $(\mathbf{A})$ e irradiada (B) em 2,0 M de guanidina.

Figura 35 Espectro de fluorescência do triptofano presente na crotamina nativa $(\mathbf{A})$ e irradiada (B) em 3,0 M de guanidina.

Figura 36 Espectro de fluorescência do triptofano presente na crotamina nativa (A) e irradiada (B) em 4,0 M de guanidina.

Figura 37 Espectro de fluorescência do triptofano presente na crotamina nativa (A) e irradiada (B) em 5,0 M de guanidina.

Figura 38 Espectro de fluorescência do triptofano presente na crotamina nativa (A) e irradiada (B) em 6,0 M de guanidina.

Figura 39 Espectro de fluorescência do triptofano presente na crotamina nativa (A) e irradiada (B) na primeira hora de análise em diferentes concentrações de guanidina.

Figura 40 Espectro de fluorescência do triptofano presente na crotamina nativa (A) e irradiada (B) na segunda hora de análise em diferentes concentrações de guanidina.

Figura 41 Espectro de fluorescência do triptofano presente na crotamina nativa (A) e irradiada (B) na terceira hora de análise em diferentes concentrações de guanidina.

Figura 42 Espectro de fluorescência do triptofano presente na crotamina nativa $(\mathbf{A})$ e irradiada (B) após 24 horas de análise em diferentes concentrações de guanidina.

Figura 43 Registro da curva de dose em DDR submetido à frequência de $0,05 \mathrm{~Hz}$. Controle $(\mathbf{A})$; crotamina nativa $(\mathbf{B})$; crotamina irradiada (C).

Figura 44 Representação da contração em DDR por tempo, sob estímulo a baixa frequência $(0,05 \mathrm{~Hz})$ na ausência (controle) e na presença de crotamina nativa e irradiada nas concentrações de $0,1 \mu \mathrm{g} / \mathrm{mL}$ e $0,5 \mu \mathrm{g} / \mathrm{mL}$. * Estatisticamente diferentes do grupo veículo, valor de $p \leq 5$.

Figura 45 Curva de contração muscular (componente fásico) versus frequência $(1,5,10$ e $20 \mathrm{~Hz})$ em diferentes doses de crotamina nativa e irradiada.

Figura 46 Curva de contração muscular (componente tônico) versus frequência $(1,5,10$ e $20 \mathrm{~Hz})$ em diferentes doses de crotamina nativa e irradiada. 


\section{Páginas}

Tabela 1 Perfil epidemiológico dos acidentes ofídicos nos últimos 100 anos por intemédio das principais variáveis utilizadas por 30 trabalhos publicados.

Tabela 2 Principais características, propriedades e potenciais aplicações biotecnológicas da crotamina.

Tabela 3 Valores de intensidade de fluorescência do triptofano para os diferentes valores de pressão. 


\section{LISTA DE ABREVIATURAS E SIGLAS}

ACh - acetilcolina

ADP - adenosina difosfato

AFM - Atomic Force Microscopy

AMP - adenosina monofosfato

AMP - peptídeo antimicrobiano

Arg - arginina

Asp - ácido aspártico

ATP - adenosina trifosfato

CD - Dicroísmo Circular

CEVAP - Centro de Estudos de Venenos e Animais Peçonhentos $\mathrm{Co}^{60}$ - Cobalto-60

COMT - catecol-O-metiltransferase

CPP - cell penetrating peptide

Cys - cisteína

DDR - ducto deferente de rato

DL50 - dose letal média

GFP - Green Fluorescent Protein

Gln - glutamina

Glu - ácido glutâmico

Gly - glicina

$\mathrm{H}^{1}$-RMN - Ressonância Magnética Nuclear Homonuclear

His - histidina

HPLC - High Performance Liquid Chromatography

HPSEC - High Performance Size Exclusion Chromatography

$\mathrm{IC}_{50}$ - half maximal inhibitory concentration

Ile - isoleucina

$\mathrm{IP}_{3}$ - trifosfato de inositol

IT-TOF - Ion Trap Time of Flight

Leu - leucina

Lys - lisina

MAO - monoamino oxidase 
Met - metionina

MS - Mass Spectrometry

OMS - Organização Mundial da Saúde

PBS - phosphate buffered saline

$\mathrm{pH}$ - potencial hidrogeniônico

Phe - fenilalanina

pl - ponto isoelétrico

$\mathrm{PLA}_{2}$ - fosfolipase $\mathrm{A}_{2}$

PLC - fosfolipase C

Pro - prolina

RMN - Ressonância Magnética Nuclear

RP-HPLC - Reverse Phase High Performance Liquid Chromatography

SAXS - Espalhamento de Raios $X$ a Baixo Ângulo

SDS-PAGE - eletroforese em gel de poliacrilamida

Ser - serina

TTX - tetrodotoxina

Tyr - tirosina

UNIFESP - Universidade Federal Paulista 


\section{INTRODUÇÃO}

O estudo farmacológico e bioquímico do veneno de animais e de suas toxinas é da mais alta importância sob múltiplos aspectos. Somente por meio dele é possível adquirir conhecimento adequado da fisiopatologia dos envenenamentos e instituir medidas racionais e eficientes em seu tratamento. Assim, diversos estudos de venenos animais têm revelado substâncias promissoras em terapêutica. Rocha \& Silva, em 1948, descobriram os peptídeos hipotensores de venenos botrópicos que serviram como modelo para o desenho de drogas, como o Captopril®, muito usadas atualmente por hipertensos. Várias outras substâncias, derivadas de toxinas de serpentes, têm sido estudadas, como a Reptilase ${ }^{\circledR}$, utilizada como anticoagulante; a enzima com estrutura homóloga à trombina de Bothrops atrox, que permite a detecção e quantificação de fibrinogênio, mesmo em pacientes tratados com um anticoagulante, como a heparina; o Protac $\AA$, um ativador de proteína $\mathrm{C}$, utilizado em pessoas com alto risco de trombose vascular, dentre outros (Bon, 1994). Mais recentemente, venenos de serpentes têm revelado vasta aplicação como agente antitumoral. $O$ uso de veneno para o tratamento de câncer em laboratório de experimentação animal foi reportado primeiramente por Calmette, 1907. Hernandez-Plata e cols. (1993) relataram ação antitumoral da peçonha de Crotalus durissus terrificus ao tratarem as células de sarcoma de animais de laboratório in vivo, com frações de crotamina e do complexo crotoxina. Os resultados tanto em relação a regressão do tumor, quanto à sobrevida dos animais foram excelentes. Estudos sobre a caracterização de substâncias presentes no veneno de Crotalus durissus terrificus responsáveis pela ação antinociceptiva têm mostrado pelo menos três compostos do veneno que exercem essa função: a crotamina (Mancin e cols., 1998), o peptídeo crotalfina (Konno e cols., 2007) e a crotoxina (Brigatte, 2005). Atualmente muitas pesquisas mostram a completa remissão de células tumorais após 0 tratamento com moléculas derivadas de venenos de serpente (Vyas e cols., 2013).

De acordo com o exposto acima fica evidente o grande potencial que as toxinas de venenos apresentam em relação às inúmeras aplicações terapêuticas. Sendo assim, um vasto estudo ainda se faz necessário para 
esclarecer o modo de ação de tais toxinas, bem como a influência direta da sua estrutura conformacional nos efeitos biológicos apresentados.

\subsection{Acidentes ofídicos}

Os acidentes causados por serpentes venenosas representam importante problema de saúde pública, especialmente em países tropicais, devido às elevadas taxas de morbimortalidade. A maioria dos acidentes causados por serpentes peçonhentas ocorre em países em desenvolvimento, sendo mais frequente em áreas rurais, onde os dados epidemiológicos são pouco notificados. De acordo com dados estatísticos provenientes do Serviço Nacional de Informações Tóxico-farmacológicas, do Ministério da Saúde, os acidentes causados por serpentes venenosas ocupam o segundo lugar nas taxas de intoxicação humana, superados apenas pelas reações causadas por remédios (Bonan e cols., 2010).

No Brasil, evidenciou-se que, em média, ocorrem 20.000 acidentes causados por serpentes peçonhentas ao ano, com mortalidade próxima de 0,45\%. Esses dados revelam alguns índices da realidade brasileira, entretanto, desde 1901, após o estudo precursor de Vital Brazil, pouco se publica sobre esse assunto (Bochner e Struchiner, 2003; Bonan e cols., 2010). Segundo os últimos dados fornecidos pelo Ministério da Saúde, foram notificados cerca de 26.000 acidentes em 2008, sendo que a maioria das notificações é procedente das regiões meridionais do país.

A Tabela 1 apresenta o perfil epidemiológico dos acidentes ofídicos segundo as principais variáveis utilizadas pelos artigos revisados no trabalho de Bochner e Struchiner, 2003. 
Tabela 1: Perfil epidemiológico dos acidentes ofídicos nos últimos 100 anos por intemédio das principais variáveis utilizadas por 30 trabalhos publicados*.

\begin{tabular}{ll}
\hline Variáveis & Perfil epidemiológico \\
\hline Indivíduo & \\
Vítima & Homem \\
Sexo & Masculino \\
Idade & 15 a 49 anos \\
Profissão/Ocupação & Lavrador
\end{tabular}

\section{Evento}

Zona

Rural

Mês do acidente

Novembro a abril

Horário do acidente

Diurno

Circunstância do acidente

Trabalho

Local da picada

Membros inferiores

Gênero

Bothrops

\section{Atendimento}

Tratamento anterior

Garroteamento

Tempo decorrido entre $o$ atendimento e

Menos de 6 horas

0 acidente

Manifestações clínicas

Locais: dor, edema

Sistêmicas: insuficiência renal, hemorragia

Utilização de soro

Em mais da metade dos casos

Reação à soroterapia

Ausente na maioria dos casos

Classificação da gravidade do acidente

Moderado

Evolução

Letalidade geral de 0,45\% (Bothrops: 0,31\%;

Crotalus: 1,87\%; Lachesis: 0,95\%; Micrurus:

$0,52 \%)$

*Adaptado de Bochner e Struchiner, 2003.

De acordo com tais dados, é possível realizar uma comparação com o perfil apresentado por Vital Brazil em seu livro de 1901:

- A jararaca é a espécie que determina a maior parte dos acidentes, fato que harmoniza com a abundância em que é encontrada e com a sua distribuição geográfica na região Sul Americana; 
- Os homens são vitimados com maior frequência do que as mulheres, o que se explica perfeitamente pelo tipo de trabalho adotado geralmente por um ou por outro sexo;

- Os indivíduos maiores de 15 anos são vitimados com maior frequência;

- Os membros inferiores são os mais atingidos em cerca de 75\% dos casos (Bochner e Struchier, 2003).

Frente ao exposto, fica claro que os acidentes ofídicos representam um problema de saúde pública negligenciado pelos órgãos competentes, uma vez que não existem estudos atuais que evidenciem o panorama geral destes acidentes no Brasil. Embora aparentemente os relatos de Vital Brazil possam ser extrapolados para estimativas recentes, não é possível substanciar de forma quantitativa o que realmente tem ocorrido no país nos últimos anos.

Ainda pode-se observar na Tabela 1 que acidentes com o gênero Bothrops são os que apresentam maior incidência, porém, os acidentes decorrentes do gênero Crotalus são os mais letais. De acordo com dados de 2008 do Ministério da Saúde (Figura 1), aproximadamente 75\% dos acidentes ocorrem com serpentes pertencentes ao gênero Bothrops. As serpentes dos gêneros Crotalus, Lachesis e Micrurus contribuem com cerca de 7,5\%, 3,0\% e $1,0 \%$ dos casos, respectivamente. Cabe ressaltar que estes dados referem-se à acidentes nos quais o gênero da serpente é informada; em aproximadamente $15 \%$ dos casos tal informação não é obtida.

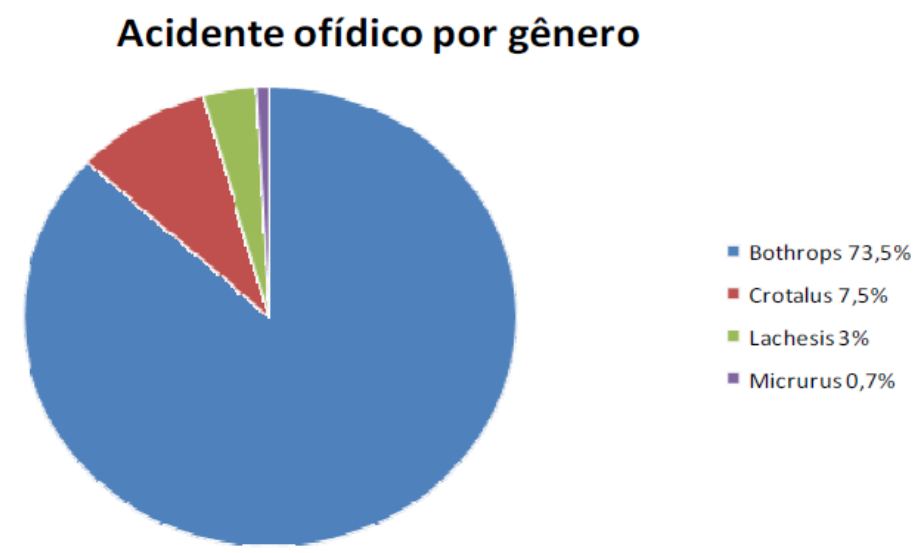

Figura 1: Porcentagem de acidentes ofídicos por gênero de acordo com o Ministério da Saúde, 2008 (adaptado de Catarino, 2011). 
Como já mencionado anteriormente, o gênero Crotalus não apresenta a mais expressiva incidência de acidentes em território nacional, porém é o responsável pela maior letalidade em comparação com os demais gêneros. Cerca de $72 \%$ dos casos de acidentados sem o tratamento adequado com soro específico (soro anticrotálico) chegam ao óbito e apenas $11 \%$ dos casos tratados corretamente atingem tal situação (Rosenfeld, 1971). Considerando especificamente a espécie Crotalus durissus terrificus, cujo veneno é objeto deste estudo, dados revelam que cerca de $14 \%$ dos acidentes ofídicos no Brasil são decorrentes da espécie, apresentando ainda alta taxa de mortalidade (Cardoso e cols., 2003; Ferreira Júnior e cols., 2006).

\subsection{O veneno crotálico e seus componentes}

As serpentes do gênero Crotalus estão representadas no Brasil por apenas uma espécie, a Crotalus durissus, e distribuídas em cinco subespécies: Crotalus durissus terrificus, encontrada nas zonas altas e secas da região sul oriental e meridional; Crotalus durissus collilineatus, distrubuídas nas regiões secas do centro-oeste, Minas Gerais e norte de São Paulo; Crotalus durissus cascavella, encontrada nas áreas da caatinga do nordeste; Crotalus durissus ruruima, observada na região norte do país; Crotalus durissus marajoensis, observada na ilha de Marajó (Pinho \& Pereira, 2001). Na Figura 2 é possível observar a distribuição da espécie Crotalus durissus no Brasil.

Tais serpentes são popularmente conhecidas por cascavel, boicininga, maracambóia ou maracá. São encontradas em campos abertos, áreas secas, arenosas e pedregosas, raramente na faixa litorânea. Não possuem hábito de atacar e, quando ameaçadas, denunciam sua presença pelo ruído característico do guizo ou chocalho presente na cauda (Pinho \& Pereira, 2001). 


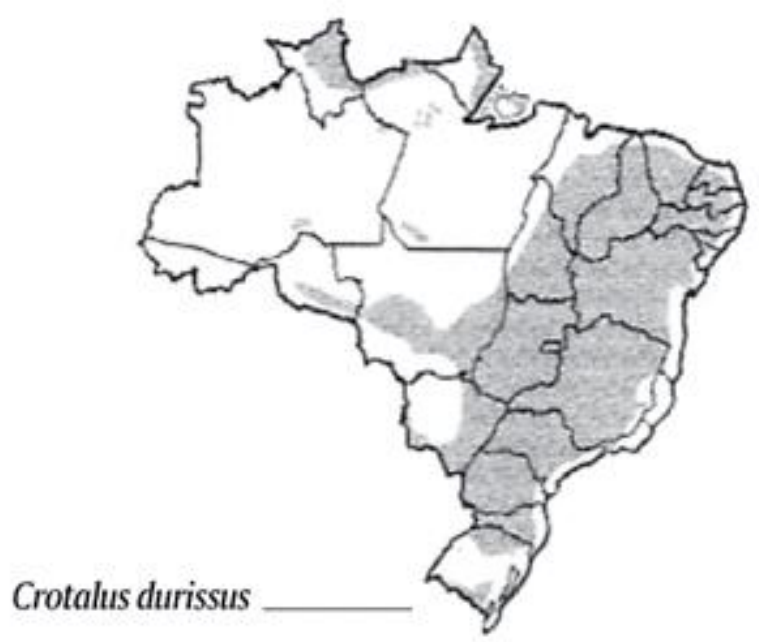

Figura 2: Distribuição da espécie Crotalus durissus no território brasileiro (adaptado de Tokarnia e Peixoto, 2006).

No caso específico do veneno da subespécie Crotalus durissus terrificus (Figura 3), há 5 componentes farmacologicamente ativos identificados até então: convulxina, delta toxina, giroxina, crotoxina e crotamina.

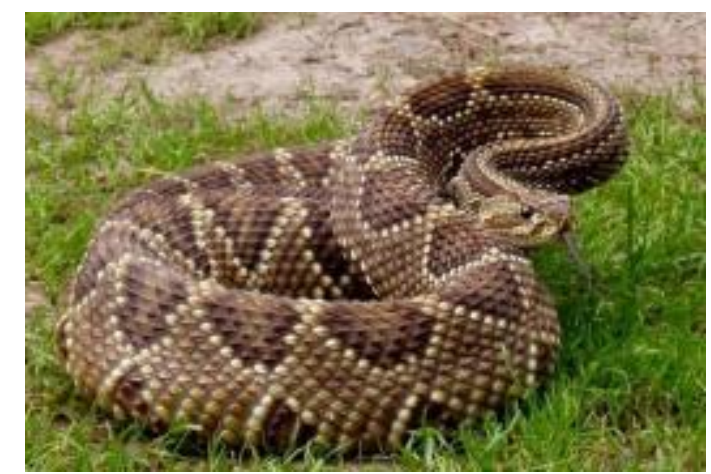

Figura 3: Serpente da espécie Crotalus durissus terrificus (Lima, 2010).

A convulxina foi descoberta após observarem que efeitos de alterações respiratórias e circulatórias não poderiam ser atribuídas às toxinas já isoladas na época, como a crotoxina e a crotamina. Isolada em 1970 por Prado-Franceschi, a convulxina é uma glicoproteína neurotóxica de alta massa molecular, cerca de $70 \mathrm{kDa}$, que provoca distúrbios no sistema nervoso autônomo; tais efeitos se caracterizam por convulsões tônico-crônicas, alterações circulatórias e respiratórias, ativação e agregação plaquetária na ausência de fibrinogênio (Prado-Franceschi, 1970; Campos, 2006). 
A delta toxina foi assim denominada por Vital-Brazil, em 1980, ao sugerir a existência de uma toxina que eluiria entre a convulxina e a giroxina quando o veneno era fracionado por cromatografia de exclusão molecular e que estaria envolvida na agregação plaquetária, alteração da permeabilidade vascular, além de causar grande hemoconcentração. Apenas em 2006, Campos isolou e caracterizou a delta toxina, ao mostrar que a proteína com massa molecular de $40 \mathrm{kDa}$ ativa agregação plaquetária em concentrações muito baixas. Campos sugeriu também, em termos conformacionais, se tratar de um homotrímero cujos componentes estão unidos por ligações fracas.

A giroxina é uma serino protease com efeitos neurotóxicos. Foi parcialmente caracterizada por Barrio em 1961, que descreveu a giroxina como uma neurotoxina não-letal, responsável pela indução de uma síndrome neurológica em ratos. Este efeito caracteriza-se por movimentos circulatórios do corpo ao longo de seu eixo longitudinal, similares ao rolamento de um barril. A giroxina ainda apresenta atividade coagulante do fibrinogênio no plasma de mamíferos, exercendo assim uma atividade do tipo trombina (Alexander e cols., 1988).

A crotoxina é o principal componente tóxico do veneno da Crotalus durissus terrificus, representando cerca de $70 \%$ de sua massa total. Foi a primeira neurotoxina animal a ser purificada e cristalizada (Slotta \& FraenkelConrat, 1938). É formada por duas subunidades associadas de forma não covalente: fosfolipase $\mathrm{A}_{2}\left(\mathrm{PLA}_{2}\right)$, uma subunidade básica com massa molecular de $14 \mathrm{kDa}$; e a crotapotina, subunidade ácida, com massa molecular de 9,2 kDa (Faure \& Bon, 1988). A crotoxina exerce sua função fisiopatológica por inibir a transmissão neuromuscular, bloqueando a liberação de acetilcolina (ACh) (Hortnagel \& Hanin, 1992). Em adição aos seus efeitos pré-sinápticos, a crotoxina também age de forma pós-sináptica bloqueando a resposta à ACh ao manter o receptor colinérgico em um estado conformacional inativo (Vital Brazil \& Excell, 1971; Vital Brazil e cols., 1966; Hanley, 1979; Bon e cols., 1979, Faure \& Bon, 1988). A atividade da crotoxina depende do sinergismo entre as duas subunidades, sendo que a crotapotina age como proteína chaperone, inibindo ligações inespecíficas da $\mathrm{PLA}_{2}$ e potencializando a sua ação neurotóxica (Bon e cols., 1989; Hernandez-Oliveira e cols., 2005). Estudos mais recentes têm mostrado que a crotapotina isolada do complexo crotoxina 
(espécie C.d.terrificus) também apresenta atividade biológica, como por exemplo, a inibição da resposta inflamatória à carragenina em edema na pata traseira de ratos (Landucci e cols., 1995; Oliveira e cols., 2003).

A crotamina, objeto deste estudo, foi primeiramente isolada, por meio de métodos eletroforéticos, por Gonçalves \& Vieira (1950). Possui massa molecular de 4,8 kDa e é composta por 42 aminoácidos (Laure, 1975), apresentando, dentre outros resíduos, 7 resíduos de aminoácidos aromáticos: 1 tirosina, 2 histidinas, 2 triptofanos e 2 fenilalaninas. É uma toxina extremamente básica, com ponto isoelétrico $(\mathrm{pl})=10.3$ (Gonçalvez, 1956) devido à presença de 11 aminoácidos básicos (9 lisinas e 2 argininas). Estes aminoácidos promovem uma superfície carregada positivamente para estes peptídeos (Kerkis e cols., 2014).

A toxina é reticulada por 6 cisteínas ligadas por pontes dissulfeto, fato que confere à crotamina alta estabilidade conformacional (Hampe e cols., 1978). O N-terminal é a tirosina e o C-terminal é a glicina (Boni-Mitake e cols., 2001). A Figura 4 ilustra a sequência da estrutura primária da crotamina com a indicação das 3 pontes dissulfeto formadas.

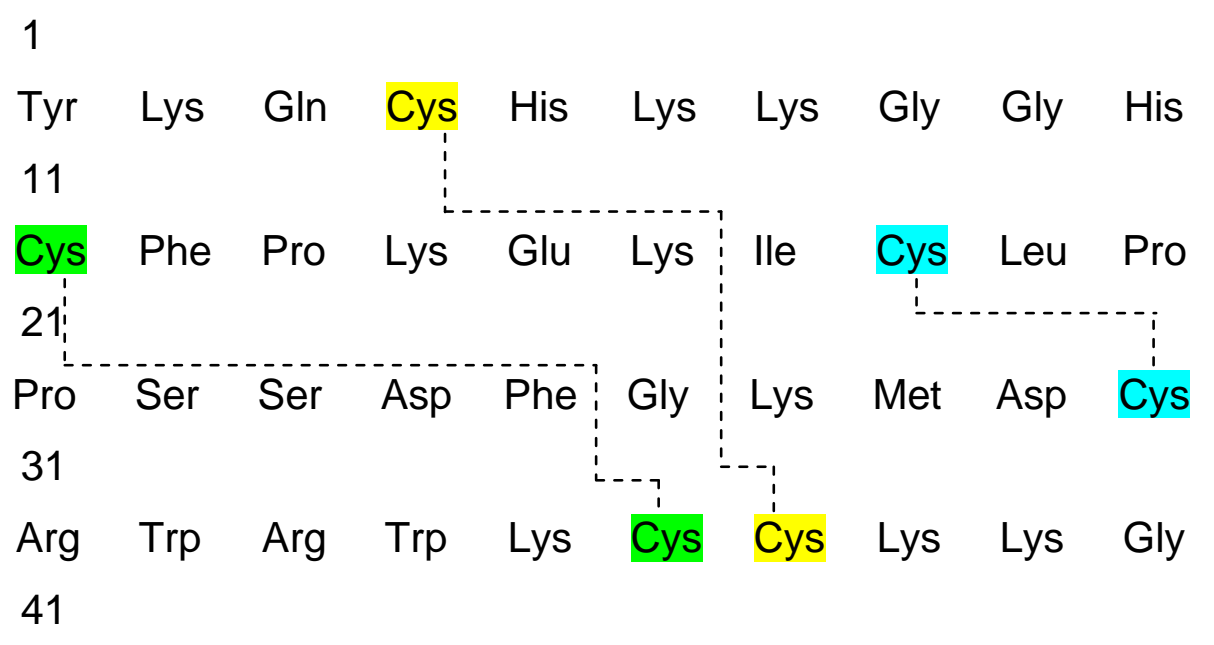

Ser Gly

Figura 4: Sequência primária da crotamina com indicação das pontes dissulfeto (Beltran e cols., 1990).

Gonçalves \& Arantes (1956) mostraram que a quantidade de crotamina no veneno de cascavel é extremamente variável perfazendo de 9,6 a $53,7 \%$ do veneno total. A constituição do veneno de C.d.terrificus, devido à 
presença de crotamina pode ser denominada crotamina-positivo ou crotaminanegativo. As serpentes que possuem venenos crotamina-positivo podem ser encontradas ao oeste do Estado de São Paulo e os venenos crotaminanegativo, ao leste do Estado, tendo ainda uma região que é híbrida, na qual coexistem ambos os tipos de veneno (Schenberg, 1959; Oguiura, 1998).

\subsubsection{Aspectos estruturais da crotamina}

Estudos relacionados à estrutura tridimensional da crotamina icluem espectroscopia Raman (Kawano e cols., 1982), espalhamento de Raios-X a baixo ângulo - SAXS (Beltran e cols., 1990), ressonância magnética nuclear homonuclear - ${ }^{1} \mathrm{H}-\mathrm{RMN}$ (Endo e cols., 1989; Nicastro e cols., 2003), modelagem computacional (Siqueira e cols., 2002) e ressonância magnética nuclear - RMN (Fadel, 2005).

Em 1989, Endo e cols. sugeriram que a crotamina apresentava dois estados conformacionais diferentes em solução. Tais estruturas coexistiriam e poderiam refletir o isômero cis-trans dos resíduos de prolina ou poderia ocorrer uma dimerização da molécula com uma ponte dissulfeto intermolecular fazendo a ligação entre as duas subunidades.

Siqueira e cols. (2002), por meio de modelagem computacional, propuseram uma estrutura estável composta por duas folhas $\beta$ e regiões aleatórias.

Por meio de ressonância magnética nuclear homonuclear - ${ }^{1} \mathrm{H}-\mathrm{RMN}$ Nicastro e cols. (2003), mostraram inicialmente a existência de três segmentos folha $\beta$ antiparalelas (resíduos 9-12, 24-25 e 35-38), três do tipo $\beta$-turns (resíduos 13-16, 27-30 e 31-34) e o N-terminal estruturado com $\alpha$-hélice (envolvendo os resíduos de 3-7), interligados por estrutura aleatória. Consequentemente foi sugerido que a toxina era formada com topologia $\alpha \beta_{1} \beta_{2} \beta_{3}$.

Entretanto, Fadel em 2005, utilizando a técnica de RMN, não conseguiu identificar a formação de uma terceira folha $\beta$, propondo então a topologia $\alpha \beta_{1} \beta_{2}$ (Figura 5). 


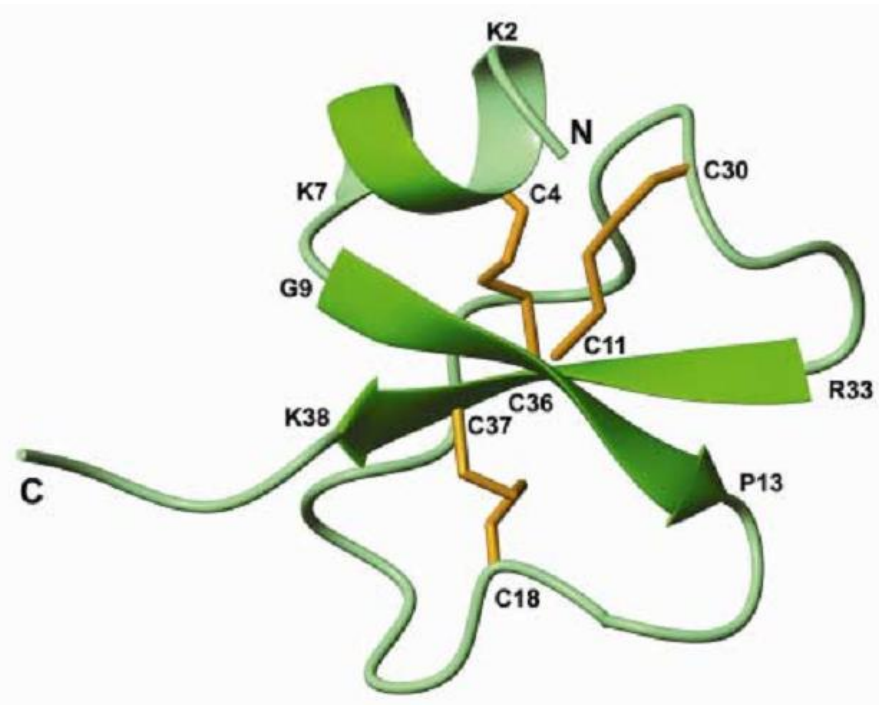

Figura 5: Estrutura tridimensional da crotamina resolvida por RMN (Fadel, 2005).

Em 2013, Coronado e cols. isolaram e determinaram a estrutura cristalográfica da crotamina (Figura 6). Pode-se notar uma nova proposta para a conformação da toxina, cuja formação topológica foi classificada como $\alpha_{1} \beta_{1} \alpha_{2} \beta_{2}$. A estrutura $\alpha_{1}$ é formada pelos resíduos de lisina $(2-7)$. $\mathrm{Na}$ sequência, observa-se a formação de duas estruturas do tipo folha $\beta$ antiparalela, formada pelos resíduos glicina-9 a prolina-13 $\left(\beta_{1}\right)$ e triptofano-34 a lisina-38 $\left(\beta_{2}\right)$, localizadas na região interna da molécula. Uma pequena $\alpha$-hélice é formada pelos resíduos prolina-20 a serina-23. A toxina, como já mencionado anteriormente, é estabilizada por 3 pontes dissulfeto (destacadas em amarelo na Figura 6): cisteína-4 e cisteína-36, cisteína-11 e cisteína-30, cisteína-18 e cisteína-37. Cabe ressaltar que tais ligações entre os resíduos de cisteínas são diferentes daquelas propostas por Beltran e cols. (1990) (Figura 4). A ponte formada pelos resíduos cisteína-4 a cisteína-36 fixa o segmento entre a estrutura $\alpha_{1}$ e $\beta_{2}$. Já as formações $\beta_{1}$ e $\alpha_{2}$ são conectadas por um loop flexível entre os resíduos de lisina-14 a leucina-19. Outro loop mais extenso e flexível, formado entre os resíduos ácido aspártico-24 a arginina-33, conecta as estruturas $\alpha_{2}$ e $\beta_{2}$. As formações do tipo folha $\beta$ são estabilizadas por pontes de hidrogênio que conectam as estruturas $\beta_{1}$ e $\beta_{2}$, envolvendo os resíduos histidina-10 a cisteína-37 e fenilalanina-12 a lisina-35. As pontes de hidrogênio entre as estruturas $\beta_{2}$ e $\alpha_{2}$ são formadas pelos resíduos serina-23 a lisina-38. 
Duas pontes de hidrogênio conectam ainda a estrutura $\beta_{2}$ a região C-terminal em $\beta$-turn (Coronado e cols., 2013).

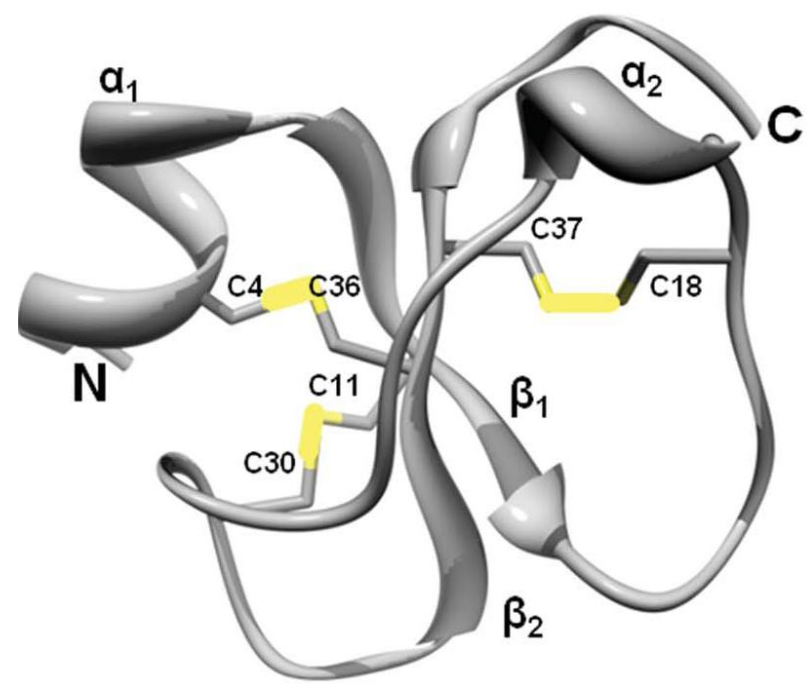

igura 6: Conformação estrutural da crotamina. Em amarelo estão representadas as pontes dissulfeto (Coronado e cols., 2013).

O modelo estrutural revelado por Coronado e cols. (2013) indicou ainda uma distribuição assimétrica de cargas na superfície da proteína (Figura 7), uma vez que resíduos básicos (grupo positivo) como arginina e lisina, são predominantes na superfície da proteína (região azul) em comparação com resíduos ácidos (grupo negativo), como ácido aspártico e glutâmico (região vermelha).
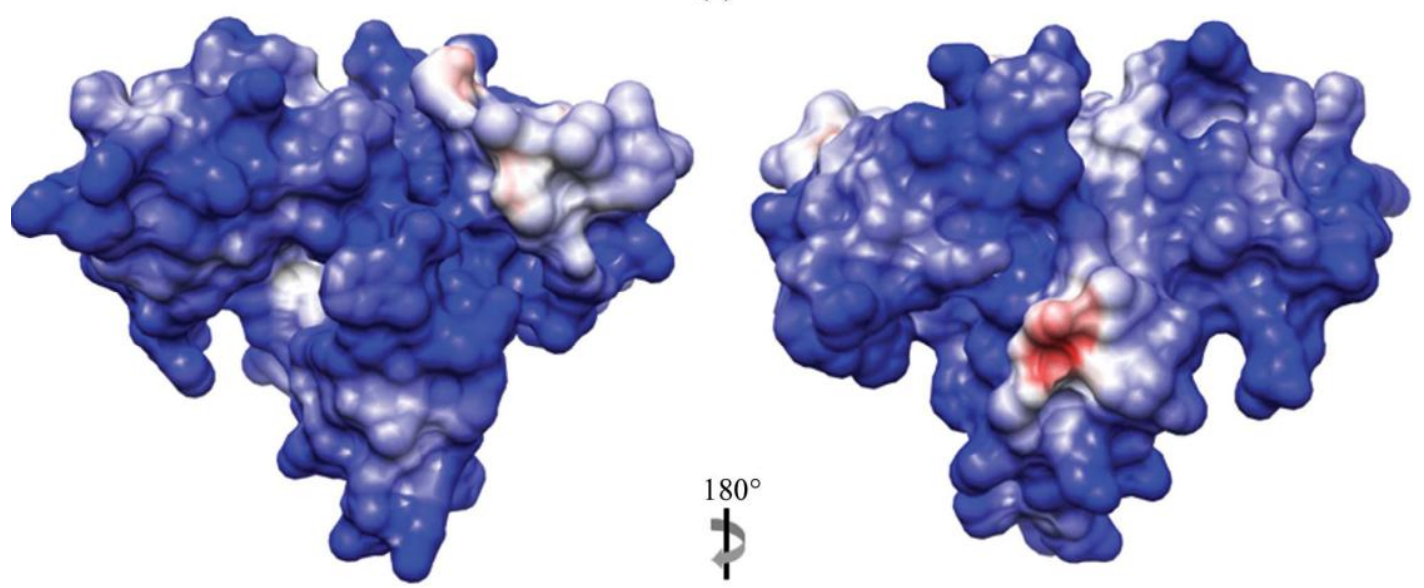

Figura 7: Distribuição da superfície de cargas na estrutura da crotamina em duas orientações distintas. Superfície azul indica a presença de resíduos básicos (arginina e lisina) e a superfície vermelha indica a presença de resíduos ácidos (ácido aspártico e ácido glutâmico) (Coronado e cols., 2013). 
Assim, regiões catiônicas (predominantes) e regiões hidrofóbicas estão localizadas em lados opostos da molécula, o que, por sua vez, explica um possível modo de interação com fosfolípedes carregados negativamente e outros alvos moleculares, justificando as diversas atividades farmacológicas da crotamina.

Ainda em relação à interação da crotamina com outras moléculas, cabe dizer que esta é facilitada por três fatores principais, a saber: a toxina é relativamente pequena quando comparada com outras proteínas, sendo muitas vezes classificada como um peptídeo; a crotamina está toda carregada, apresentando regiões positivas e negativas localizadas em lados opostos da molécula como já mencionado anteriormente; e os seus resíduos hidrofóbicos estão expostos ao solvente. Sendo assim, forças eletrostáticas e hidrofóbicas na superfície protéica, em combinação com a formação molecular da crotamina estabilizada por três pontes dissulfeto, tornam a crotamina uma proteína capaz de se ligar a proteínas alvo (Coronado e cols, 2013).

\subsubsection{Apectos farmacológicos da crotamina}

Estudos iniciais referentes aos efeitos biológicos da crotamina revelaram a capacidade da toxina em induzir contratura do músculo esquelético, tanto in situ quanto em preprarações isoladas, de alguns animais, como gatos, cachorros, ratos e camundongos (Moussatché e cols., 1956; Gonçalves, 1956; Cheymol e cols., 1971; Vital-Brazil e cols., 1978). Além disso, observou-se também que a ação miotóxica da crotamina causa paralisia espástica dos membros posteriores e dificuldade respiratória. Na Figura 8 pode-se observar o efeito paralisante da crotamina em camundongo.

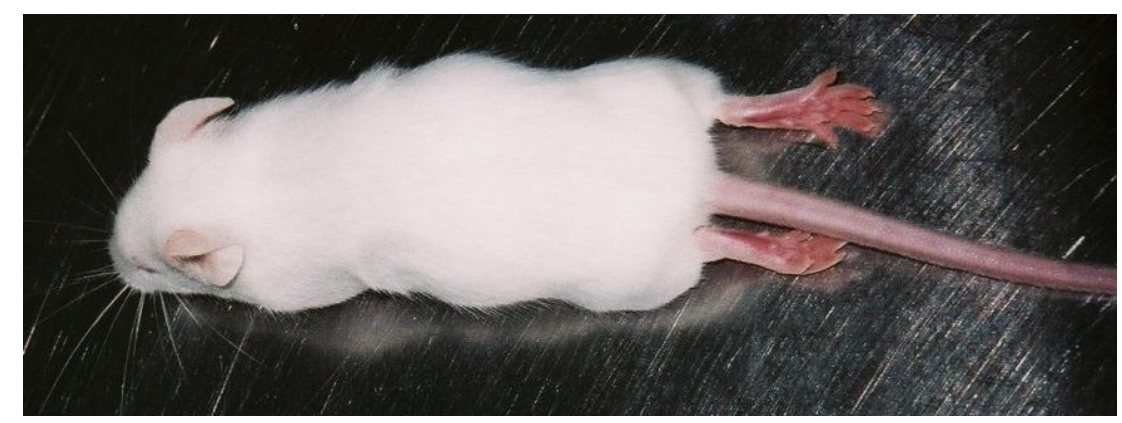

Figura 8: Efeito da crotamina nos membros posteriores (Casare, 2008). 
Em diafragma de ratos, a crotamina provoca contratura imediata seguida por contração irregular espontânea (Cheymol e cols., 1971) e despolariza o potencial de repouso da membrana em cerca de $25 \%$ (Pellegrini Filho e cols., 1978).

Quando investigaram a despolarização da membrana, em músculo diafragma de camundongos e rato, induzida pela crotamina, Chang e Tseng (1978) inferiram que a ação da toxina se dava diretamente sobre o canal de $\mathrm{Na}^{+}$ou em seu modulador, o qual é responsável por regular a permeabilidade do canal de $\mathrm{Na}^{+}$em musculatura murina. Propuseram ainda que $\circ \mathrm{K}^{+}$ extracelular poderia deprimir a permebilidade do canal de $\mathrm{Na}^{+}$do sarcolema por agir na mesma molécula regulatória.

Em 1983 Hong e Chang observaram que a tetrodotoxina (TTX), uma neurotoxina que bloqueia especificamente os canais de $\mathrm{Na}^{+}$nas membranas de células excitáveis, bloqueando assim o potencial de ação da membrana, evitou e também restaurou a despolarização do potencial de membrana causado pela crotamina, mas não impediu ligações irreversíveis. Assim, inferiram que o sítio de interação da TTX é distinto do sítio de ação da crotamina.

Depois de diversos estudos mostrando evidências indiretas de que a crotamina age nos canais de $\mathrm{Na}^{+}$, Rizzi e cols. (2007) demonstraram que a toxina, na realidade não afeta diretamente os canais voltagem-dependente de $\mathrm{Na}^{+}$. Tais resultados também foram sustentados pela diferença no comportamento do envenenamento pela crotamina e toxinas cuja atividade é comprovadamente nos canais de $\mathrm{Na}^{+}$(TTX, $\mu$-conotoxin-GIIla, BclII, Tx2-6 e $\alpha$ e $\beta$-pompilidotoxinas), as quais foram incapazes de mimetizar a paralisia nos membros posteriores causada pela crotamina. Este estudo relatou ainda que a toxina age de maneira diferente em músculos fast e slow-twitching, apresentando preferência por inativar o fast-twitching.

Yount e cols. (2009) propuseram que a crotamina poderia agir como uma bloqueadora dos canais voltagem-dependente de $\mathrm{K}^{+}$, devido a sua semelhança estrutural com $\beta$-defensinas antimicrobianas de humanos. Esses resultados sugeriram que a crotamina interage com sítios específicos no poro do canal de $\mathrm{K}^{+}$. 
Peigneur e cols. (2012), com o intuito de detalhar a ação da crotamina em canais de potássio, realizaram estudos eletrofisiológicos em 16 canais (12 clones de canais de potássio e 4 clones de canais de sódio) expressos em ovos da espécie Xenoupus laevis e verificaram propriedades eficientes da crotamina em inibir canais de potássio, confirmando assim as sugestões de Yount e cols. (2009) e também a inabilidade de interação da crotamina com os canais de sódio, como Rizzi e cols. (2007) já haviam mostrado.

Embora estudos mais recentes apontem para um mecanismo de ação diferente daquele inicialmente proposto, ainda não há um consenso em relação à maneira com a qual a crotamina age sobre a musculatura esquelética.

\subsubsection{Demais atividades da crotamina}

A estrutura geral da crotamina é homóloga a peptídeos antimicrobianos (AMPs) pertencentes as famílias $\alpha$-defensinas, $\beta$-defensinas e defensinas de insetos (Dimarcq e cols., 1998), como já mencionado anteriormente. Além disso, tais estruturas possuem o mesmo número de pontes dissulfeto (Hoover e cols., 2003). Funcionalmente, defensinas apresentam um amplo espectro de atividades e desencadeiam diversos efeitos. Alguns destes peptídeos possuem atividade anti-Gram-positivo e participam em reações antibacterianas (Cociancich e cols., 1994).

De forma similar aos AMPs, a crotamina é altamente solúvel em água e é capaz de interagir fortemente com membranas biológicas. Assim, alguns trabalhos têm demonstrado a ação da crotamina em adentrar células, sendo o primeiro peptídeo de veneno a ser classificado como um CPP (cell penetrating peptide) (Rodrigues e cols., 2012). Em contraste com outros CPPs e AMPs naturais, a crotamina tem demonstrado um amplo espectro de atividades biológicas com potenciais aplicações biotecnológicas e terapêuticas, principalmente em atividades antimicrobianas e anti-fúngicas (Yamane e cols., 2013).

Mais recentemente estudos demonstraram a atividade seletiva da crotamina por células tumorais (Papo \& Shai, 2005; Pereira e cols., 2011; 
Kerkis e cols., 2014). Testes in vivo, com monitorção em tempo real, usando o modelo de melanoma murino, evidenciaram que a toxina retarda a implantação do tumor, inibe a proliferação celular e também aumenta a sobrevida de ratos com melanoma subcutâneo induzido. Este estudo também demonstrou que a inibição do crescimento tumoral envolve despolarização mitocondrial e liberação de cálcio intracelular. Esses dados indicam que a crotamina poderia ser usada para duas propostas iniciais: apontar e detectar o crescimento tumoral em tecidos e também dar início a morte das células tumorais (Nascimento e cols., 2011; Kerkis e cols., 2014).

A Tabela 2 resume algumas das principais características, propriedades e potenciais aplicações biotecnológicas da crotamina.

Tabela 2: Principais características, propriedades e potencias aplicações biotecnológicas da crotamina*.

\begin{tabular}{ll}
\hline Nome & Crotamina \\
\hline Organismo & Crotalus durissus terrificus \\
& Nome popular: cascavel \\
Classificação & Mioneurotoxina, CPP, AMP, peptídeo defensina-like \\
Massa molecular & 4726,63 daltons \\
Quantidade de aminácidos & 42 aminoácidos \\
Sequência primária & KQCHKKGGHCFPKEKICLPPSSDFGKMDCRWRWKCCKKGSG \\
Solubilidade & Altamente solúvel em água e soluções fisiológicas \\
Estabilidade & Alta estabilidade em soluções, em diferentes pHs e temperatura \\
& Paralisia nas patas traseiras de ratos em concentração de 2,5 \\
Atividades fisiológicas & mg de toxina/kg de massa corpórea \\
& Necrose de células musculares \\
Atividade eletrofisiológica & $\begin{array}{l}\text { Bloqueador de canais de potássio (Kv1.1, Kv1.2 e Kv1.3) com } \\
\text { IC }(50) \text { de 286,53 } \pm 91,72 \text { nM }\end{array}$ \\
Toxicidade in vitro (células & Não tóxica (entre concentrações de 0,1 a 10 $\mu$ M) \\
normais) & Seletiva: ativa nas células em proliferação \\
Atividade célula penetrante & Depende da concentração, tipo de célula e ciclo celular \\
(CPP) in vitro & Citosol, vesículas, núcleo, centríolos e cromossomos \\
Localização intracelular & Ação modesta em bactérias Gram-positiva e Gram-negativa, \\
como algumas exceções; detectável atividade contra fungos na & concentração de 125 $\mu$ g/mL \\
Atividade antimicrobiana & Significante atividade contra Candida spp \\
&
\end{tabular}


Toxicidade em células

tumorais

Atividade antitumoral (in

vitro)

Atividade antitumoral (in vivo)

Mecanismo de inibição tumoral

Imunogenicidade

Aplicações biotecnológicas

e biomédicas
Tóxica (concentrações de 0,1 a $10 \mu \mathrm{M}$ )

Forte ação em células de melanoma

Inibição e retardo do crescimento de melanoma em ratos

Despolarização mitocondrial

Liberação de cálcio intracelular

Baixa

Marcador de centríolos e ciclo celular; marcador da proliferação de células normais; carreador de biomoléculas; ferramenta para a investigação de tumores; marcador de células tumorais in vitro e in vivo; agente antitumoral e antifúngico; protótipo para novas drogas.

*(adaptado de Kerkis e cols., 2014).

\subsection{Soroterapia e a radiação ionizante}

Como já descrito, o envenenamento por picada de serpente representa um sério problema de Saúde Pública, especialmente em áreas tropicais. Calmette (1907) já definia a soroterapia como o melhor meio terapêutico e também destacava a relação direta entre a especificidade do antisoro para o gênero da serpente e a eficiência do tratamento.

No Brasil, os equinos são empregados na produção de soro contra o veneno de nossas serpentes desde 1901 (Vital Brazil). Embora estes animais apresentem grande porte, sofrem durante o processo de imunização, pois devido à baixa imunogenicidade, grandes quantidades de veneno são inoculadas a fim de obter-se uma produção eficiente de anticorpos, o que afeta diretamente sua longevidade e condições de bem estar (Rosenfeld, 1971).

Com o intuito de melhorar a produção de soro e bem estar dos animais, Phisalix \& Bertrand (1894) realizaram os primeiros estudos objetivando diminuir a toxicidade dos venenos utilizados na imunização de equinos. Desde então, diversos processos têm sido utilizados com o propósito de diminuir a letalidade das toxinas, como por exemplo: iodação (Heneine e col., 1992; Daniel e cols., 1987; Bicalho e cols., 1990), fotooxidação (Shortt \& 
Mallick, 1935), irradiação com raios-X (Flowers, 1963), ultravioleta (Tejasen \& Ottolenghi, 1970) e mutagênese sítio dirigida (Li e cols., 1994).

A radiação ionizante, a exemplo das metodologias citadas anteriormente, vem sendo utilizada na destoxicação de venenos de serpentes. Esta técnica apresenta um diferencial em relação às demais, visto que além de conseguir diminuir a toxicidade do veneno, mantém, ou por vezes até melhora, as propriedades imunológicas da amostra irradiada, sem que seja adicionada outra substância a mesma (Puranananda, 1972; Kankonkar e cols., 1975; Hati e cols., 1989; Mandal e cols., 1991, 1993; Nascimento e cols., 1996; Ferreira Júnior e cols., 2006; Caproni e cols., 2009).

A radiação ionizante consiste de ondas eletromagnéticas formadas a partir de transições nucleares, tendo alta energia, ausência de massa (no caso da radiação gama), bem como a capacidade de promover ionização e excitação nos meios, possuindo um alto poder de penetração (Grosh \& Hoopywood, 1979). Seus efeitos podem ser diretos ou indiretos, sendo o primeiro uma consequência da interação direta com componentes celulares como o DNA, proteínas e lipídeos, provocando alterações estruturais em suas moléculas, o que constitui cerca de $30 \%$ do efeito biológico das radiações. 0 efeito indireto se dá quando a radiação interage com as moléculas de água presentes no meio intracelular, formando os chamados produtos da radiólise da água $(\mathrm{OH} \bullet, \mathrm{H} \bullet$, elétron aquoso e outros). Este efeito, denominado radiólise da água, corresponde à cerca de $70 \%$ do efeito biológico produzido pelas radiações e sua maior ocorrência, deve-se ao fato de a água ocupar grande parte da composição celular (Michaels \& Hunt, 1978).

Esses produtos da radiólise da água passam por uma variedade de reações, incluindo a abstração de hidrogênio, transferência de elétrons (oxidação ou redução do substrato), adição, fragmentação e rearranjo, dimerização e substituição de aminoácidos, peptídeos e proteínas (Hawkins \& Davies, 2001). Nestas últimas, ainda, a interação dos produtos da radiólise da água com aminoácidos das cadeias protéicas, promove desaminação (Butler e cols., 1987; Garrison, 1987). Apesar de estes efeitos ocorrerem ao acaso, alguns sítios podem ser mais favoráveis, devido à transmissão de energia intramolecular. 
No que diz respeito à ação da radiação em materiais biológicos, o processo é iniciado por várias interações físicas, que dependem dos átomos presentes e da natureza química do sistema (Butler e cols., 1984).

A irradiação de proteínas, no estado seco ou em solução aquosa, pode induzir uma série de alterações na estrutura protéica, indo desde simples ionizações, até alterações drásticas na sua estrutura primária. Podem ocorrer alterações oxidativas decorrentes da interação dos radicais livres primários, produzidos após a radiólise da água, com a molécula de proteína, alterando sua estrutura e podendo conferir à mesma, cargas negativas (Wales \& Kusel, 1992). Ainda observam-se alterações químicas como fragmentação, "crosslinking" e agregação (Moon \& Song, 2001).

A agregação de proteínas in vivo pode apresentar problemas sérios afetando a saúde humana, como nos casos das doenças: Alzheimer, Parkinson, amiloidose, prions e doenças tumorais. A diversidade de doenças que resultam de conformação inadequada de proteínas tem feito deste tema um importante foco para companhias farmacêuticas e de biotecnologia (Lansbury, 1999; Foguel \& Silva, 2004).

No caso da proteína de interesse ser tóxica para as células hospedeiras, a atenuação da toxicidade por radiação se apresenta como uma ótima ferramenta. Em proteínas que apresentem pontes dissulfídicas, a formação de agregados protéicos é esperada.

Alguns trabalhos têm mostrado que após o processo de irradiação, a proteína sofre alterações na estrutura terciária e secundária, fato que está diretamente relacionado às mudanças nas suas funções biológicas. Em alguns casos inclusive, depois de irradiadas, as proteínas em solução apresentam agregados insolúveis visíveis a olho nu. Sabe-se que parte da amostra pode revelar ainda formas intermediárias de conformação que se apresentam como agregados solúveis (Andriani, 1995; Guarnieri, 1992; Murata, 1988; Nascimento, 1991/1995; Spencer, 1995/1999; Casare, 2009). 


\subsection{Alta Pressão Hidrostática}

Altas pressões hidrostáticas modulam interações proteína-proteína e proteína-solvente por meio de alterações nos volumes e consequentemente afetando o equilíbrio de espécies conformacionais de proteínas entre o estado nativo e desnaturado, bem como formas monoméricas, oligoméricas e agregados (Paladini, 1981). Termodinamicamente as altas pressões favorecem a conformação protéica que reduz o volume do sistema total. Agregados são mais densos, relativamente à conformação nativa, conseqüentemente $O$ tratamento sob pressão modula a dissociação de agregados e a renaturação. A alta pressão hidrostática desagrega e renatura proteínas de agregados, desfavorecendo interações hidrofóbicas e eletrostáticas intermoleculares. Em contraste, as pontes de hidrogênio não são sensíveis à alta pressão hidrostática devido à desprezível mudança de volume associada à quebra dessas pontes (Randolph e cols., 2002). Para facilitar a quebra das pontes de hidrogênio entre proteínas nos agregados, a temperatura pode ser elevada nas amostras sob pressão e/ou pequenas concentrações de agentes caotrópicos como guanidina podem ser incluídos nas soluções protéicas. A alta pressão também não quebra pontes dissulfídicas que fazem ligações cruzadas covalentes entre agregados de proteínas. Nos casos de polipeptídeos contendo aminoácidos cisteína, um par oxido-redutor é incluído nas soluções de pressurização de modo a facilitar a quebra das ligações dissulfídicas intermoleculares e formação de pontes dissulfídicas nativas.

Desagregação e renaturação sob alta pressão é um método fundamentalmente diferente de obtenção de proteínas nativas a partir de agregados insolúveis, não nativos quando comparada aos métodos tradicionais utilizando-se altas concentrações de agentes caotrópicos. Sob pressão, as etapas de solubilização e renaturação podem ocorrer utilizando as mesmas condições de processamento $e$ as proteínas não necessitam ser completamente desnaturadas a fim de liberá-las dos agregados. Com as técnicas tradicionais, quando a concentração de agente caotrópico é reduzida, tanto as pontes de hidrogênio como as interações hidrofóbicas não nativas se tornam favorecidas, geralmente resultando em reagregação. Em contraste, sob 
pressão, as interações hidrofóbicas intermoleculares são inibidas, enquanto a renaturação nativa pode ocorrer.

Estas propriedades fazem da alta pressão uma ferramenta útil para dissociação de agregados protéicos em proteínas nativas, facilitando a preparação de proteínas para estudos estruturais e funcionais e também para aplicações em indústria biotecnológica (Kim e cols., 2006).

Estudos recentes têm mostrado que pressões hidrostáticas moderadas (1-3 kbar) são uma alternativa atrativa às técnicas tradicionais de desnaturação e diluição, tanto em termos de rendimentos, quanto de simplicidade no processo. Assim, esta técnica tem demonstrado relevante potencial para aumentar rendimentos de proteínas, com conformação nativa e atividade biológica, a partir de agregados (Gorowitz, 1998; Lefebvre e cols., 2004; Seefeldt e cols., 2004; Kim e cols., 2006). Por exemplo, o processo de renaturação por alta pressão hidrostática levou a altos rendimentos (>90\%) de proteínas nativas a partir de agregados de hormônio de crescimento recombinante e pontes dissulfídicas de agregados de lisozima, mesmo em altas concentrações protéicas em estudos que utilizaram agregados induzidos in vitro por stress como altas temperaturas e agitação (St. John e cols., 1999, 2001, 2002).

Considerando-se o poder da radiação em modificar proteínas, melhorando seu potencial imunológico e que as mudanças estruturais promovidas são as responsáveis pelas alterações de cunho biológico já demostradas, é de grande valia elucidar a relação entre as transformações conformacionais e as consequentes alterações na atividade da toxina irradiada, relação esta que ainda não está totalmente descrita. 


\section{OBJETIVOS}

Geral:

Caracterizar a crotamina presente no veneno crotálico em seu estado nativo e irradiado com raios gama de $\mathrm{Co}^{60}$.

\section{Específicos:}

- Isolar e purificar a crotamina a partir do veneno bruto de Crotalus durissus terrificus por meio de técnicas cromatográficas;

- Caracterizar a toxina, nos estados nativo e irradiado, por meio das seguintes técnicas:

- Fluorescência;

- Dicroísmo Circular;

- Microscopia de Força Atômica;

- Alta Pressão Hidrostática.

- Avaliar os efeitos da crotamina nativa e irradiada sobre a neurotransmissão e contração da musculatura lisa de ratos. 


\section{MATERIAL E MÉTODOS}

O veneno de C.d.terrificus utilizado para os experimentos realizados neste trabalho foi gentilmente cedido pelo Centro de Estudo de Venenos e Animais Peçonhentos - CEVAP, situado na cidade de Botucatu.

Todos os reagentes utilizados na realização dos experimentos foram de qualidade pró-análise. A água utilizada para o preparo das soluções foi procedente de um sistema de ultrapurificação (Milli $\left.{ }^{\circledR}\right)$.

\subsection{Isolamento das toxinas}

A cromatografia é uma técnica físico-química de grande importância na separação de misturas e identificação de seus componentes. Está fundamentada na migração diferencial dos componentes de uma mistura, que ocorre devido a diferentes interações, entre duas fases imiscíveis, a fase móvel e a fase estacionária (fixa). A grande variedade de combinações entre fases móveis e estacionárias a torna uma técnica extremamente versátil e de grande aplicação (Bastos, 2008).

Quanto ao modo de separação, a cromatografia pode ser dividida em adsorção, partição, troca iônica, exclusão molecular ou ainda a mistura desses mecanismos (Degani e cols., 1998).

Em relação à exclusão molecular, também chamada de gel filtração, o princípio de separação está fundamentado na diferença entre o tamanho das moléculas (volume hidrodinâmico) ou componentes da mistura, sendo que os solutos maiores passam com maior velocidade pela coluna. No caso ideal, a exclusão molecular é uma técnica cromatográfica em que não há interações atrativas entre a fase estacionária e o soluto.

Considerando-se a cromatografia de troca iônica, íons, ânions ou cátions, estão ligados covalentemente à fase estacionária sólida (resina). Os íns do soluto, com carga oposta, são atraídos para a fase estacionária por forças de natureza eletrostática. A configuração eletrônica dos compostos será alterada de acordo com o pH da solução (Bastos, 2008).

Outra técnica cromatográfica muito utilizada em sistemas de alta performace, do tipo HPLC (High Performance Liquid Chromatography) é 
denominada fase reversa. A HPLC de fase reversa (RP-HPLC) baseia-se no princípio de interações hidrofóbicas. Consiste em uma fase imóvel apolar e uma fase móvel de polaridade moderada. Uma das fases estacionárias mais comuns deste tipo de cromatografía é a sílica tratada com $\mathrm{RMe}_{2} \mathrm{SiCl}$, onde o $\mathrm{R}$ é uma corrente alquil tal como $\mathrm{C}_{18} \mathrm{H}_{37}$ ou $\mathrm{C}_{8} \mathrm{H}_{17}$. O tempo de retenção é maior para as moléculas de natureza apolar, enquanto as moléculas de carácter polar eluem mais rapidamente (Collins e cols., 2006).

\subsubsection{Cromatografia de exclusão molecular}

A crotamina foi inicialmente isolada, a partir do veneno bruto de C.d.terrificus, por meio de exclusão molecular em coluna de gel filtração Superdex 75 10/300 GL acoplada ao cromatógrafo AKTA (GE Life Science). Em cada cromatografia, cerca de $10 \mathrm{mg}$ do veneno total liofilizado foram dissolvidas em $600 \mu \mathrm{L}$ de tampão formiato de amônio 200 mM, pH 3,0. A seguir a solução foi centrifugada a $14000 \mathrm{~g}$ por 5 minutos em uma microcentrífuga. $\mathrm{O}$ sobrenadante foi aplicado à coluna de gel filtração, já ambientada em mesmo tampão, com fluxo de $0,8 \mathrm{~mL} / \mathrm{min}$. As frações foram coletadas (1,0 $\mathrm{mL}$ por tubo) com o auxílio de um coletor automático do próprio sistema de HPLC. Toda a eluição foi acompanhada pela leitura da absorvância a $280 \mathrm{~nm}$ em um espectrofotômetro. A fração de interesse foi separada em recipiente adequado e posteriormente liofilizada em liofilizador E-C Modulyo.

\subsubsection{Cromatografia de troca iônica}

A fração correspondente à crotamina, já liofilizada, foi ressuspendida em tampão fosfato de sódio $50 \mathrm{mM}, \mathrm{pH}$ 7,8 (tampão A) e aplicada em uma resina do tipo Mono S (troca catiônica), em sistema HPLC (AKTA - GE Life Science), estabilizada no mesmo tampão. Após a adsorção da proteína, esta foi eluída com gradiente linear de 0 a $2 \mathrm{M}$ de $\mathrm{NaCl}$ (tampão $\mathrm{A}+2 \mathrm{M}$ de $\mathrm{NaCl}$ ). A absorvância em $280 \mathrm{~nm}$ foi monitorada durante todo o processo cromatográfico. Posteriormente a crotamina foi dialisada em membrana adequada (limite máximo de corte de $3 \mathrm{kDa}$ - SIGMA ${ }^{\circledR}$ ), contra água e de 
maneira exaustiva ( 3 trocas no volume de $2 \mathrm{~L}$ cada). Após nova liofilização, a crotamina foi armazenada em freezer $\mathrm{a}-20^{\circ} \mathrm{C}$.

\subsubsection{Cromatografia de exclusão molecular de alta eficiência (HPSEC)}

A cada fase cromatográfica, foram aliquotados $200 \mu \mathrm{L}$ da fração de interesse (crotamina) para realização de cromatografia de exclusão molecular do tipo analítica na mesma coluna utilizada na primeira etapa de exclusão molecular (Superdex 75 10/300 GL), conectada ao sistema HPLC (AKTA - GE Life Science).

Para a primeira análise, a coluna de gel filtração foi ambientada em tampão formiato de amônio 200 mM, pH 3,0. Após a passagem de 3 vezes o volume da coluna, cerca de $100 \mu \mathrm{L}$ da amostra foram então aplicados no mesmo fluxo de equilíbrio da coluna $(0,8 \mathrm{~mL} / \mathrm{min})$. O perfil cromatográfico obtido foi monitorado pela leitura da absorvância a $280 \mathrm{~nm}$ em um espectrofotômetro acoplado ao próprio sistema.

$\mathrm{Na}$ segunda análise, as condições cromatográficas citadas acima foram mantidas, porém a alíquota de $100 \mu \mathrm{L}$ de crotamina injetada no sistema era referente à segunda etapa de isolamento da toxina (troca catiônica). Neste caso o perfil cromatográfico também foi acompanhado por medidas de absorvância a $280 \mathrm{~nm}$.

Além do uso da técnica de gel filtração analítica para a verificação do fracionamento das toxinas de interesse após cada fase cromatográfica, 0 método também foi aplicado para analisar as amostras de crotamina depois do processo de irradiação utilizando as mesmas condições descritas acima.

\subsubsection{Protocolo de fracionamento da crotamina proveniente do CEVAP}

No decorrer deste trabalho, em colaboração com o CEVAP, utilizamos também a crotamina já purificada cedida pela instituição. Assim, nesse caso, o protocolo de fracionamento da toxina seguiu diferentes etapas cromatográficas, a saber: para a purificação e isolamento da crotamina, foram realizadas duas etapas consecutivas de gel filtração, utilizando injeção de $1 \mathrm{~g}$ de veneno total crotamina-positiva, em uma coluna pré-empacotada de Gel 
Filtração Sephadex G75 (GE Healthcare Life Sciences, Uppsala, Suécia) utilizando tampão formiato de amônio $50 \mathrm{mM}+\mathrm{Nacl} 150 \mathrm{mM}$ com pH 3,5 para equilíbrio e eluição, com $0,5 \mathrm{~mL}$ por minuto em um equipamento Akta Explorer 100 AIR (GE Healthcare Life Sciences, Uppsala, Suécia). Entre a primeira e a segunda etapa de gel filtração as amostras foram liofilizadas e analisadas em gel de eletroforese (dados não mostrados).

\subsubsection{Cromatografia de fase reversa (RP-HPLC)}

Com o objetivo de analisar a amostra de crotamina fornecida pelo CEVAP foi realizada a cromatografia de fase reversa utilizando como padrão comparativo, uma amostra de crotamina proveniente do Instituto Butantan.

Nessa etapa cromatográfica utilizou-se uma coluna Vydac C-8. Inicialmente a coluna foi ambientada em $0,05 \%$ de ácido fórmico (tampão A) e após a injeção da amostra, um gradiente de 0 a 100\% de acetonitrila (grau HPLC) $+10 \%$ de ácido fórmico $0,05 \%$ (tampão B) foi aplicado na coluna para eluição da amostra (fluxo de corrida: $1,0 \mathrm{~mL} / \mathrm{min}$ ). Durante toda a corrida cromatográfica, tanto para a amostra do CEVAP quanto para a do Instituto Butantan, a leitura de absorvância foi monitorada a $280 \mathrm{~nm}$ em espectrofotômetro acoplado ao sistema HPLC, modelo SCL-10A, Shimadzu (MD, EUA).

\subsection{Dosagem protéica}

A determinação da concentração protéica da crotamina foi realizada a partir do valor do coeficiente de extinção obtido no Expasy ${ }^{1}$ (banco de sequência de proteínas) que relaciona a concentração protéica com a leitura espectrofotométrica em $280 \mathrm{~nm}$. A leitura é realizada em $280 \mathrm{~nm}$, pois nesta região do espectro é possível traduzir as bandas relativas aos cromóforos das cadeias laterais dos seguintes aminoácidos: Triptofano (Trp), Tirosina (Tyr) e Fenilalanina (Phe), bem como das pontes dissulfeto. Além destas bandas, também é possível traduzir a contribuição de outros aminoácidos não aromáticos: Metionina (Met), Cisteína (Cys) e Histidina (His) além dos grupamentos sulfidrilas livres. 
A relação estabelecida entre a leitura da absorvância e a concetração protéica provém da Lei de Lambert-Beer que pode ser escrita da seguinte maneira:

\section{$A=\varepsilon \mathbf{c} b$}

Em que A é a medida da absorvância em $280 \mathrm{~nm}$ da região ultravioleta do espectro eletromagnético; $\varepsilon$ é a absortividade molar; c é a concentração do soluto [mols/L] e b é o comprimento do caminho óptico através da amostra [cm].

\subsection{Liofilização}

Liofilização é um processo de estabilização, no qual uma substância é previamente congelada e então a quantidade de solvente é reduzida, primeiro por sublimação e posteriormente por dessorção, para valores tais que impeçam atividade biológica e reações químicas. De acordo com Baruffaldi e Oliveira (1998) o termo "liófilo" significa amigo do solvente, o que define com fidelidade as características de amostras liofilizadas: altamente higroscópicas e de fácil dissolução em solvente polares como a água.

A liofilização também denominada por outras nomenclaturas como criodesidratação ou criosecagem, é um processo diferenciado de desidratação de produtos, pois ocorre em condições especiais de pressão e temperatura, possibilitando que a água previamente congelada (estado sólido) passe diretamente ao estado gasoso (sem passar pelo estado líquido), ou seja, a mudança de estado físico ocorre por sublimação (Garcia, 2009).

O processo de liofilização é uma etapa importante em todo o fracionamento da crotamina. Além disso, manter a toxina liofilizada assegura a conservação das suas atividades biológicas. Após cada etapa cromatográfica utilizou-se a técnica de liofilização, ora para a mudança de solvente, ora para a melhor conservação da proteína.

Nessa etapa utilizou-se um liofilizador (E-C Modulyo). Inicialmente a amostra foi congelada em freezer - $20 \stackrel{\circ}{\circ}$ e após congelamento inicial, a crotamina permaneceu cerca de 30 minutos em freezer $-80 \stackrel{\circ}{\circ}$. O liofilizador 
foi previamente ligado e, após o condensador atingir - $40 \stackrel{\circ}{\mathrm{C}}$, a bomba de vácuo foi acionada. Quando a pressão atingiu o valor de $10^{-1} \mathrm{kbar}$, a amostra, já congelada, foi acoplada em recipiente específico ao sistema de liofilização.

\subsection{Irradiação das Proteínas}

A crotamina em solução PBS, na concentração de $2 \mathrm{mg} / \mathrm{mL}$, foi irradiada com raios gama provenientes de uma fonte de ${ }^{60} \mathrm{Co}$ (Gammacell 220, da Atomic Energy of Canada Limited), a temperatura ambiente e na presença de oxigênio atmosférico. A dose total utilizada foi de $2 \mathrm{kGy}$, com taxa de dose de $1,56 \mathrm{kGy} / \mathrm{h}$. Esta dose de radiação foi estabelecida por trabalhos prévios realizados em nosso laboratório que mostraram a diminuição da toxicidade do veneno de $C$.d.terrificus e suas frações, sem perda da capacidade imunogênica (Guarnieri, 1992; Nascimento e cols., 1996; Spencer, 1995/1999; Boni-Mitake, 2000; Baptista, 2004/2009; Casare, 2003/2009).

\subsection{Eletroforese em gel de poliacrilamida (SDS-PAGE)}

O gel de eletroforese é uma técnica capaz de separar moléculas que envolve a migração de partículas em um determinado gel durante a aplicação de uma diferença de potencial. As moléculas são separadas de acordo com o seu tamanho, pois as que apresentam menor massa molecular irão migrar mais rapidamente do que as com maior massa. Em alguns casos, o formato das moléculas também influencia a migração pelo gel de poliacrilamida. Alguns parâmetros afetam a resolução de separação das proteínas e/ou peptídeos, como por exemplo, a razão de acrilamida com o ligante bisacrilamida; a porcentagem de acrilamida/bisacrilamida usada para preparar os géis de resolução e de empilhamento; o pH dos tampões usados nos géis, bem como os componentes utilizados nesses tampões; o método pelo qual a amostra é separada.

O sistema típico para gel (Laemmli, 1970), o qual utiliza glicina no tampão de corrida, é capaz de resolver proteínas de massa molecular entre 200.000 até $\sim 3.000$ daltons. 
Para a realização desta análise, o gel de tricina descrito por Schagger e von Jagow (1987), foi utilizado em substituição ao gel de glicina. Este protocolo permite a resolução de peptídeos de cerca de 500 daltons.

Assim, uma alíquota de cada amostra (nativa e irradiada), foi diluída em tampão de amostra reduzido (contendo $\beta$-mercaptoetanol) e em tampão não reduzido. Posteriormente as soluções foram aquecidas a $90^{\circ} \mathrm{C}$ por 10 minutos. Em seguida foram aplicados $15 \mu \mathrm{L}$ de amostra em cada poço do gel de poliacrilamida 15\%. No mesmo gel foram aplicados padrões de massa molecular conhecido (marker 26630 Thermo Scientific). A corrente foi fixada em $25 \mathrm{~mA}$, durante aproximadamente 90 minutos. Finda a eletroforese, o gel foi corado com Coomassie blue 250-R.

\subsection{Espectrometria de massa}

Atualmente, a espectrometria de massa (MS - Mass Spectrometry) é uma técnica microanalítica utilizada para obter informação do peso molecular e de características estruturais da amostra. A espectrometria de massa é uma das mais importantes ferramentas analíticas disponíveis aos cientistas, já que é capaz de fornecer informação sobre: i) a composição elementar de amostras; ii) a estrutura molecular; iii) a composição qualitativa e quantitativa de misturas complexas; iv) a estrutura e a composição de superfícies sólidas e as proporções isotópicas de átomos em amostras ${ }^{2}$.

$\mathrm{Na}$ espectrometria de massa, alguma forma de energia é transferida à amostra para causar a sua ionização. O requisito básico para uma análise por espectrometria de massa é a formação de íons livres em fase gasosa. 0 alcance e a utilidade do método de espectrometria de massa é ditado pelo processo de ionização. Os analisadores dependem em geral da aceleração dos íons, por isso os separam de acordo com a relação massa-carga (m/z), e não apenas em função de suas massas.

Um resumo do processo integral de análise pela espectrometria de massa clássica, culminando num espectro de massa típico frequentemente encontrado na literatura é mostrado na Figura 9. 


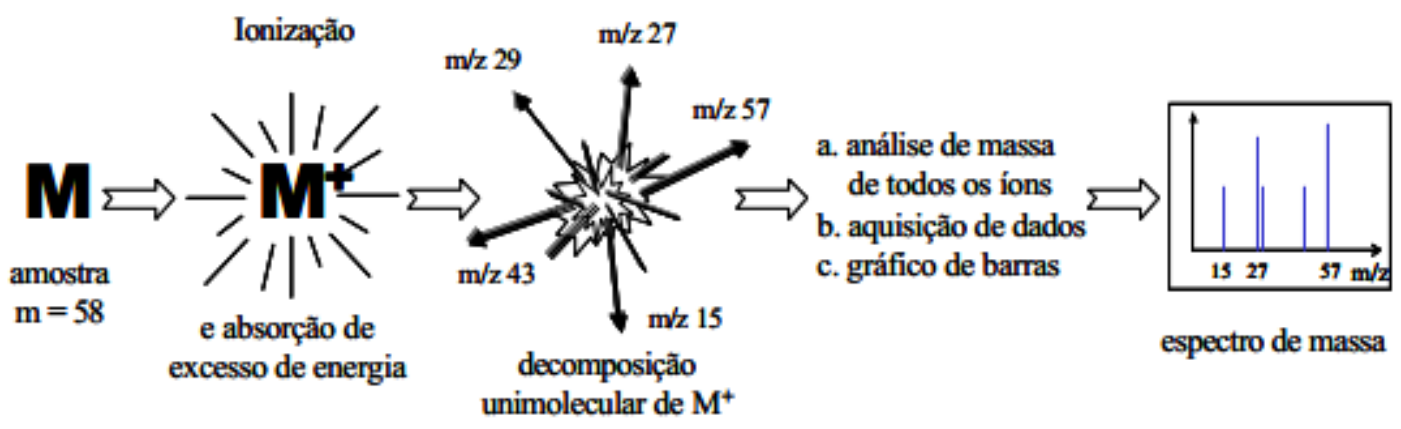

Figura 9: Esquema representativo da análise por espectrometria de massa (adaptado de http://www2.dbd.puc-rio.br/, acesso em 09 de outubro de 2013).

Para espectrometria de massa tipo electrospray, as análises foram realizadas em um instrumento IT-TOF (Shimadzu Co., Japan), no Laboratório de Bioquímica e Biofísica do Instituto Butantan. As amostras foram analisadas em modo positivo (preferencialmente), após injeção direta no instrumento sob fluxo constante de $20 \mu \mathrm{L} / \mathrm{min}$ em uma solução de $50 \%$ acetonitrila, contendo $0,5 \%$ de ácido fórmico. O controle do equipamento e aquisição dos dados foi realizado pelo software LCMS Solution e o processamento de dados pelo Mascot.

\subsection{Análise de Fluorescência}

A Fluorescência é uma técnica relevante quanto à indicação de alterações estruturais em moléculas protéicas, principalmente em relação aos compostos aromáticos.

A absorção da radiação eletromagnética de um determinado comprimento de onda por um cromóforo faz com que seus elétrons passem do estado eletrônico fundamental para o excitado. A fluorescência ocorre quando esse elétron retorna ao seu local original, emitindo um fóton (Casare, 2009).

No caso das proteínas, há apenas 3 tipos de resíduos de aminoácidos, ditos aromáticos, que podem ser responsáveis pela formação de um espectro de fluorescência: o triptofano, a tirosina e a fenilalanina.

A crotamina possui 2 resíduos de triptofano, o que permitiu a análise de fluorescência da toxina na forma nativa e irradiada, na concentração de 100 $\mu \mathrm{g} / \mathrm{mL}$ em tampão PBS, $\mathrm{pH}$ 7,2. Os dados foram obtidos em um 
espectrofotômetro de fluorescência modelo SpectraMax i3 da Molecular Devices, a $25{ }^{\circ} \mathrm{C}$. O comprimento de onda de excitação do triptofano é de 295 $\mathrm{nm}$, portanto este foi o valor utilizado na análise das amostras. O intervalo de emissão espectral considerado foi entre 300 e $400 \mathrm{~nm}$. As leituras foram efetuadas em microplaca de 96 poços, com volume final de $100 \mu \mathrm{L}$ por poço, contra um branco de tampão PBS, pH 7,2.

\subsection{Dicroísmo Circular}

A técnica de Dicroísmo Circular (CD) permite avaliar mudanças ocorridas especificamente na estrutura secundária ( $\alpha$-hélice, folha $\beta$ e estrutura randômica) da molécula, uma vez que de acordo com a estrutura protéica, a absorção de luz circularmente polarizada para a direita e para a esquerda ocorre em proporções diferentes.

No caso de proteínas e peptídeos, os cromóforos responsáveis pelo espectro de CD são: a ligação amídica, os resíduos aromáticos de triptofano, tirosina e fenilalanina, e as pontes dissulfeto.

No espectro de CD, a estrutura protéica de $\alpha$-hélice é observada como uma banda negativa próxima a $222 \mathrm{~nm}$. Isto se deve a forte ligação de pontes de hidrogênio no meio conformacional. Esta transição é relativamente independente do comprimento da hélice. A segunda transição a $190 \mathrm{~nm}$ é dividida em uma banda negativa próxima a $208 \mathrm{~nm}$ e outra banda positiva próxima a $192 \mathrm{~nm}$. Ambas as bandas são de intensidade reduzidas em pequenas hélices. $O$ espectro de $C D$ de folha $\beta$ localiza-se em uma banda negativa próxima a $216 \mathrm{~nm}$, uma banda positiva entre 195 e $200 \mathrm{~nm}$ e uma banda negativa próxima a $175 \mathrm{~nm}$. Entretanto, a posição e intensidade destas bandas são variáveis, resultando em uma menor precisão para predizer a estrutura de folha $\beta$ do que para de $\alpha$-hélice (Peltron \& McLean, 2000).

As amostras de crotamina (forma nativa e irradiada) na concentração de $100 \mu \mathrm{g} / \mathrm{mL}$ em tampão PBS, pH 7,2, foram analisadas em um espectrômetro Jasco-810 do Instituto Butantan. Para esta análise $500 \mu \mathrm{L}$ das amostras foram colocadas em celas de quartzo, com $0,1 \mathrm{~mm}$ e uma variação de comprimento 
de onda de 200 a $260 \mathrm{~nm}$. Num primeiro momento as análises foram realizadas a temperatura de $20^{\circ} \mathrm{C}$.

Com o intuito de analisar a desnaturação térmica da proteína, e entender como esta desnaturação age na mudança estrutural da crotamina, realizou-se a variação de temperatura $\left(1^{\circ} \mathrm{C} /\right.$ minuto), sendo que os dados de dicroísmo circular foram coletados em temperaturas que variaram de $20^{\circ} \mathrm{C}$ a $90^{\circ} \mathrm{C}$, a cada $10^{\circ} \mathrm{C}$. Tal procedimento foi realizado com a crotamina nativa e irradiada.

\subsection{Microscopia de Força Atômica}

O desenvolvimento da microscopia de força atômica ou Atomic Force Microscopy (AFM), por Binning, Quate e Gerber, em 1986, a partir da microscopia de tunelamento, possibilitou grande aumento na aplicação da microscopia de varredura de probe.

O princípio fundamental da técnica de AFM é a medida das deflexões de um suporte em cuja extremidade livre está montada a sonda. Estas deflexões são causadas pelas forças que agem entre a sonda e a amostra.

Os modos de obter as imagens, também chamados de modos de varredura ou de operação, referem-se fundamentalmente à distância mantida entre a sonda (ponta) e a amostra. Quando o aparelho é operado na região atrativa, o método é denominado AFM de não contato. Nesta região, o cantilever se enverga na direção da amostra. A operação na região repulsiva, é denominada AFM de contato e o cantilever se dobra, afastando-se da amostra. Ainda é possível reconhecer um terceiro modo de operação, denominado AFM de contato intermitente ou Tapping Mode. Neste caso, o cantilever oscila mantendo distâncias entre ponta e amostra. Assim, a ponta toca suavemente a superfície da amostra a cada ciclo. Tanto as forças de atração como as de repulsão agem no Tapping Mode. A Figura 10 ilustra o perfil de forças atuantes na técnica de AFM. 


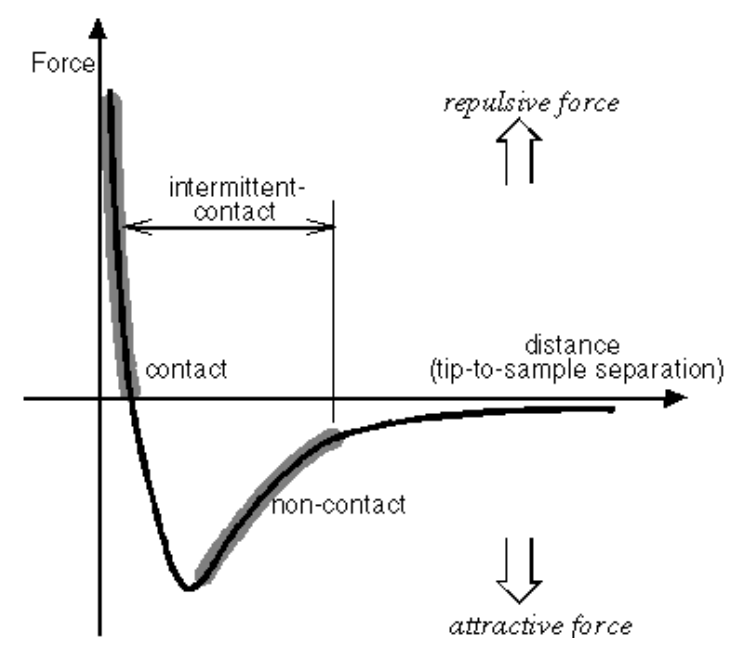

Figura 10: Gráfico da Força x Distância de separação ponta-amostra, onde são ilustradas as regiões características de cada modo de $\mathrm{AFM}^{3}$.

A crotamina, nativa e irradiada, foi diluída em solução tampão fosfato (10 mM KH $\left.\mathrm{PO}_{4}, 150 \mathrm{mM} \mathrm{KCl}, \mathrm{pH} 6,0\right)$ na concentração de $0,1 \mu \mathrm{g} / \mathrm{mL}$. Uma gota de aproximadamente $40 \mu \mathrm{L}$ da solução de crotamina foi depositada em um suporte de mica previamente preparada e o sistema foi incubado entre 15-20 minutos. A superfície de mica é comumente utilizada para obtenção de imagens topográficas de proteínas por AFM devido ao seu caráter hidrofílico, ao fato de ser atomicamante plana e de possuir alta afinidade por moléculas protéicas (Ferreira \& Yamanaka, 2006). Posteriormente cada amostra foi lavada 3 vezes em água deionizada. Todo esse processo foi realizado em capela de fluxo laminar, no sentido de evitar qualquer tipo de contaminação na superfície da amostra.

O experimento foi realizado no Laboratório de Filmes Finos do Instituto de Física da USP, em temperatura ambiente no modo AFM de contato intermitente ou Tapping Mode, técnica frequentemente utilizada no estudo de amostras biológicas delicadas, como moléculas adsorvidas fracamente ao substrato de mica.

As moléculas foram estudadas por um Scanning Probe Microscope, NanoScope IIIA, da Digital Instruments, equipado com ferramentas utilizadas em medidas de resolução atômica. Foi utilizado também o sistema ponta/cantilever de nitreto de silício, com cantilever retangular e ponta de base triangular. A varredura foi realizada pelo scanner A. O scan size escolhido para obtenção das imagens foi de $0,5 \mu \mathrm{m}$. Foram devidamente escolhidos os valores 
da amplitude de oscilação do cantilever, bem como os demais valores relacionados aos ganhos e setpoint, por exemplo.

\subsection{Teste de desnaturação}

Embora a água pura favoreça o estado nativo de uma proteína, existem várias condições que podem afetar o equilíbrio entre os estados nativo e desnaturado da mesma.

A guanidina é uma substância muita alcalina, formada a partir da oxidação da guanina, e capaz de levar a desnaturação protéica. A ação desnaturante da guanidina poderia ser decorrente de elevações na solubilidade de grupos da proteína na solução aquosa do desnaturante. Entretanto a variação favorável de energia livre de transferência de grupos da proteína para o desnaturante poderia ser decorrente da ligação das moléculas do desnaturante à ligação peptídica e/ou as cadeias laterais dos aminoácidos (Fonseca e cols., 2006).

A amostra de crotamina, no estado nativo e irradiado, foi submetida ao teste de desnaturação com diferentes concentrações de guanidina. As amostras foram preparadas em solução PBS com concentração final de 100 $\mu \mathrm{g} / \mathrm{mL}$. As concentrações de guanidina variaram de $0,5 \mathrm{M}$ a $6,0 \mathrm{M}(0,5 ; 1,0 ; 2,0$; 3,0; 4,0; 5,0 e 6,0 M). Uma solução de crotamina sem a adição de guanidina foi utilizada como controle, além do branco, formado apenas por PBS e guanidina em todas as concetrações testadas.

Para verificar a possível ação do agente desnaturante na toxina foram realizadas leituras de fluorescência (SpectraMax i3 - Molecular Devices) após a primeira hora da adição de guanidina à amostra, depois de 2, 3 e 24 horas.

\subsection{Alta Pressão Hidrostática}

A pressão é um parâmetro físico que modula as interaçãoes proteína-solvente por meio da mudança de volume do sistema (Silva \& Weber, 1993; Kim e cols., 2006). Altas pressões hidrostáticas foram descritas como capazes de solubilizar agregados e possibilitar a renaturação de proteínas 
(Fogel e cols., 1999; St. John e cols.,1999; Randolph e cols., 2002). Sob altas pressões ocorre a entrada de água nas estruturas protéicas. Pressões da ordem de 1 a 3 kbar desfavorecem interações intermoleculares hidrofóbicas e eletrostáticas, levando à dissociação de agregados. Os mesmos tipos de interação são também responsáveis pelas estruturas proteicas nos estados nativos. No entanto, normalmente as proteínas não são desnaturadas até pressões de $5 \mathrm{kbar}$ em temperatura ambiente. Então, a dissociação de complexos macromoleculares pela aplicação de pressão de até 2 a 3 kbar não é acompanhada de perda de estruturas secundárias e terciárias existentes nos estados dissociados (Silva \& Weber, 1993; Silva e cols., 2001).

Assim, para a realização do teste de renaturação protéica após o processo de irradiação, a crotamina foi diluída em tampão TRIS, $50 \mathrm{mM}, \mathrm{pH} 7,5$ na concentração final de $20 \mu \mathrm{g} / \mathrm{mL}$. Tal concentração foi confirmada previamente por leitura espectrofotométrica em $280 \mathrm{~nm}$.

As amostras da toxina nativa e irradiada foram introduzidas em recipientes adequados e o mesmo foi colocado dentro da célula de alta pressão. Todo o sistema foi devidamente fechado e pressurizado em altas pressões (1 a 3 kbar) por meio de uma bomba e um compressor de ar, utilizando-se água como fluido de transmissão. No caso do equipamento utilizado, há um fluorímetro acoplado à célula de alta pressão o que permite a leitura da fluorescência a cada mudança realizada na pressão durante todo o experimento. Dessa forma, iniciou-se a análise com a primeira leitura em pressão atmosférica. Em um segundo momento, a pressão hidrostática foi estabilizada em valor máximo de 3 kbar e assim permaneceu durante 1 hora. Durante este período foram realizadas leituras de fluorescência do triptofano a cada 15 minutos, totalizando 5 leituras ao final desta etapa. Após a primeira hora de análise a pressão hidrostática foi diminuída para 2,5 kbar e assim permaneceu durante mais 30 minutos. Nessa etapa foram realizadas duas leituras de fluorescência, uma assim que a pressão foi diminuída e outra ao término dos 30 minutos. Esse processo foi realizado até que o sistema atingisse a pressão atmosférica novamente, ou seja, a cada 30 minutos a pressão foi diminuída em 0,5 kbar e duas leituras foram realizadas para cada etapa, uma no início do novo patamar de pressão e outra ao final do mesmo patamar. 
Outra análise da crotamina irradiada foi realizada, porém com algumas alterações quanto à variação da pressão hidrostática. Nesse momento realizaram-se aferições com a pressão crescente, com variação de $1.10^{-3} \mathrm{kbar}$ (pressão atmosférica) a 3 kbar. Assim, iniciou-se a análise sob pressão atmosférica e a cada 30 minutos a pressão foi aumentada em 0,5 kbar. Em cada passo foi realizada uma leitura de fluorescência, como já mencionado para a análise em pressões decrescentes. Ao retornar ao valor inicial, ou seja, sob pressão atmosférica, mais uma leitura foi realizada com o objetivo de verificar se a fluorescência permaneceria semelhante ou não àquela obtida no início do experimento.

\subsection{Ensaios biológicos}

\subsubsection{Animais}

Foram utilizados 40 ratos Wistar machos com em média 4 a 5 meses de idade e peso ao redor de $350 \mathrm{~g}$. Os ratos foram obtidos no Biotério de Experimentação Animal Leal Prado (UNIFESP), mantidos em ambiente controlado (temperatura entre $23^{\circ} \mathrm{C}$ a $25^{\circ} \mathrm{C}$, ciclo de $12 / 12$ horas claro/escuro), recebendo água e alimento à vontade. Foram respeitadas as normas técnicas $\mathrm{e}$ bioéticas, o projeto foi submetido e aprovado pelo Comitê de Ética da UNIFESP sob o número 3304241113 (em anexo).

\subsubsection{Experimentos de contração muscular "in vitro"}

\subsubsection{Isolamento dos ductos deferentes}

A eutanásia dos animais foi realizada por inalação de $\mathrm{CO}_{2}$. Após essa etapa inicial, os animais foram preparados para o procedimento cirúrgico, no qual se realizou uma incisão abdominal que permitiu a remoção dos ductos deferentes dos ratos (DDR). Estes, uma vez retirados, tiveram seus tecidos adjacentes separados e a luz dos ductos foi lavada com o líquido nutritivo. Com o auxílio de instrumentação cirúrgica (pinça e tesoura) os tecidos adjacentes, como vasos sanguíneos e tecido adiposo, foram retirados. Uma seringa com 
líquido nutritivo foi utilizada para a remoção da secreção interna na luz do órgão.

\subsubsection{Solução nutritiva}

Para os experimentos de contração in vitro foi utilizado o Líquido Nutritivo Tyrode normal com a seguinte composição: $\mathrm{NaCl}(138,0 \mathrm{mM}), \mathrm{KCl}(2,7$ $\mathrm{mM}), \mathrm{MgCl}_{2}(1,0 \mathrm{mM}), \mathrm{CaCl}_{2}(1,4 \mathrm{mM}), \mathrm{NaH}_{2} \mathrm{PO}_{4}(0,36 \mathrm{mM}), \mathrm{NaHCO}_{3}(12,0$ $\mathrm{mM})$, Glicose (5,5 mM), $\mathrm{pH} 7,4$.

\subsubsection{Aparelhagem e montagem da preparação}

Para o estudo da contração muscular, a aparelhagem utilizada foi uma cuba de vidro com dupla parede onde internamente localizava-se a câmara muscular com capacidade para $5,0 \mathrm{~mL}$ e uma serpentina helicoidal que fornecia solução nutritiva à câmara muscular. Uma bomba de circulação impulsionava água aquecida à $37^{\circ} \mathrm{C}$ pelo lado externo da câmara, aquecendo a serpentina e a câmara muscular. A solução nutritiva foi aerada constantemente com carbogênio $\left(95 \% \mathrm{O}_{2}\right.$ e $\left.5 \% \mathrm{CO}_{2}\right)$ (foto em anexo). O ducto deferente foi montado na câmara muscular, fixando-se, por meio de um fio de algodão, uma extremidade na terminação "S" da haste da aeração sendo a outra extremidade ligada a uma alavanca de registro a um transdutor isométrico (LSI LETICA®) sendo submetido a uma tensão de 1,0 g. Para os estudos envolvendo estimulação elétrica, dois eletrodos de platina, acoplados a um estimulador, foram adaptados à câmara muscular, paralelamente ao ducto deferente.

Os sinais dos transdutores de força, gerados pela contração isométrica do músculo liso foram enviados a um amplificador (ETH-400 Bridge Amplifier). Em seguida a aquisição dos dados foi realizada por um programa denominado Powerlab/4SP, que está acoplado a um microcomputador. O programa de computador Chart v4.2 foi utilizado para o registro e análise de dados.

Uma vez ajustada a aparelhagem, o ducto deferente ficou em repouso por cerca de 45 minutos, sendo lavado a cada 15 minutos para a estabilização da preparação. Em alguns protocolos, após o período de 
estabilização, foi inicialmente adicionada ao banho, uma concentração única máxima de cloreto de potássio $(80 \mathrm{mM})$ para servir de referência como efeito máximo da preparação. Em seguida foram iniciados os protocolos experimentais na presença de concentrações crescentes realizados por dose única de crotamina nativa e irradiada nas seguintes concentrações: $0,1 \mu \mathrm{g} / \mathrm{mL}$ e $0,5 \mu \mathrm{g} / \mathrm{mL}$, realizado em baixa frequência $(0,05 \mathrm{~Hz})$.

\subsubsection{Estudo da capacidade de liberação de neurotransmissores}

O estudo da capacidade de neuroliberação de transmissores foi realizado por estimulação elétrica do tecido na ausência (controle) e na presença da crotamina.

\subsubsection{Contrações isométricas induzidas por estimulação elétrica}

A amplitude da contração obtida para cada frequência foi medida em gramas de tensão por gramas de tecido do ducto deferente. As frequências a partir de $1 \mathrm{~Hz}$ foram consideradas para análise dos resultados nos componentes fásico e tônico de contração. Os ductos deferentes foram estimulados eletricamente a uma voltagem de $70 \mathrm{~V} \operatorname{com} 3,0 \mathrm{~ms}$ de duração, nas frequências de $0,05,1,5,10$ e $20 \mathrm{~Hz}$, parâmetros esses que estimulam somente 0 tecido neuronal. A contração causada por cada frequência foi registrada por 30 segundos, com 10 minutos de intervalo entre os estímulos. $\mathrm{A}$ contração obtida com a frequência de $0,05 \mathrm{~Hz}$ se apresenta na forma de twitches (contrações rápidas, fásicas). Com frequências mais altas (1, 5, 10 e $20 \mathrm{~Hz}$ ) a contração se torna mais intensa e com característica bifásica, com um componente rápido inicial (contração fásica) seguido de um componente tônico de instalação mais lenta. A contração obtida para cada frequência foi medida em gramas de tensão por gramas de tecido. A Figura 11 mostra um registro típico das contrações obtidas nessas frequências. 


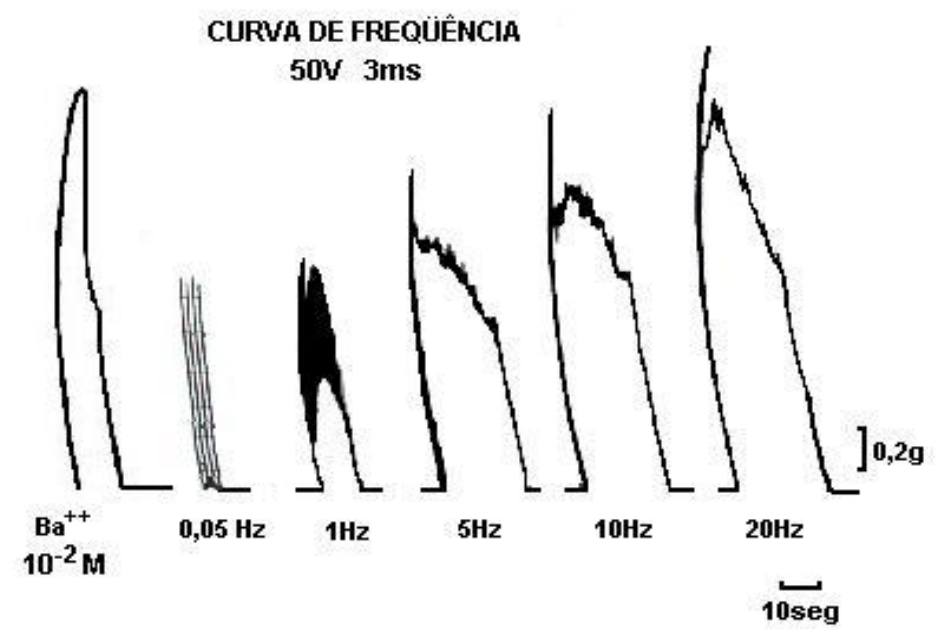

Figura 11: Registro típico da contração do ducto deferente de rato, induzida pelo cloreto de bário e pela estimulação elétrica em frequências crescentes entre 0,05 a 20,0 Hz (50 V, 3,0 ms) (Souza, 2007).

\subsection{Análises Estatísticas}

Os ensaios farmacológicos foram apresentados como média \pm erro padrão da média. Foi realizada a análise de variância (ANOVA) seguida do teste de Turkey para todos os dados obtidos nos ensaios. A probabilidade de $p \leq 0,05$ foi considerada estatisticamente significante. 


\section{RESULTADOS}

A seguir serão apresentados os resultados referentes ao fracionamento do veneno total da C.d.terrificus para obtenção da crotamina isolada, bem como os dados obtidos a partir das seguintes análises: gel de eletroforese (SDS-PAGE), Espectrometria de Massa (MS), Fluorescência, Dicroísmo Circular (CD), Microscopia de Força Atômica (AFM), desnaturação por guanidina, análise sob alta pressão hidrostática e testes biológicos de contração muscular in vitro.

\subsection{Isolamento da crotamina}

A Figura 12 apresenta o perfil cromatográfico da primeira etapa de fracionamento (exclusão molecular) do veneno total da C.d.terrificus. O pico 1 indica a fração correspondente à convulxina, o pico 2, a correspondente à delta toxina, o pico 3 é a fração referente à giroxina, o pico 4 corresponde à crotoxina e o pico 5 refere-se à fração correspondente à crotamina. Os picos 6 e 7 possivelmente representam a fração analgésica e os tripeptídeos, respectivamente. A crotamina (pico 5) é o objeto de interesse neste trabalho.

Cabe ressaltar que o perfil cromatográfico apresentado na Figura 12 não ilustra claramente o pico 2, corresponde à delta toxina. Vital Brazil (1980) sugeriu a existência de uma toxina que eluiria entre a convulxina e a giroxina quando o veneno é fracionado por cromatografia de exclusão molecular e que estaria envolvida na agregação plaquetária, alteração da permeabilidade vascular e causar grande hemoconcentração. Análises mais recentes, com resinas de maior resolução, permitiram a observação e o estudo do pico da delta toxina (Casare, 2003; Campos, 2006), porém mudanças na técnica cromatográfica aplicada, como tampão e fluxo de corrida, podem influenciar diretamente a sepração das proteínas, especialmente as de alta massa molecular. Assim, embora a literatura descreva a presença da delta toxina entre os picos 1 e 3, convulxina e giroxina respectivamente, não foi possível observar relevância em tal região diante dos parâmetros utilizados para esta análise cromatográfica inicial (Perfis cromatográficos de trabalhos anteriores em anexo). 


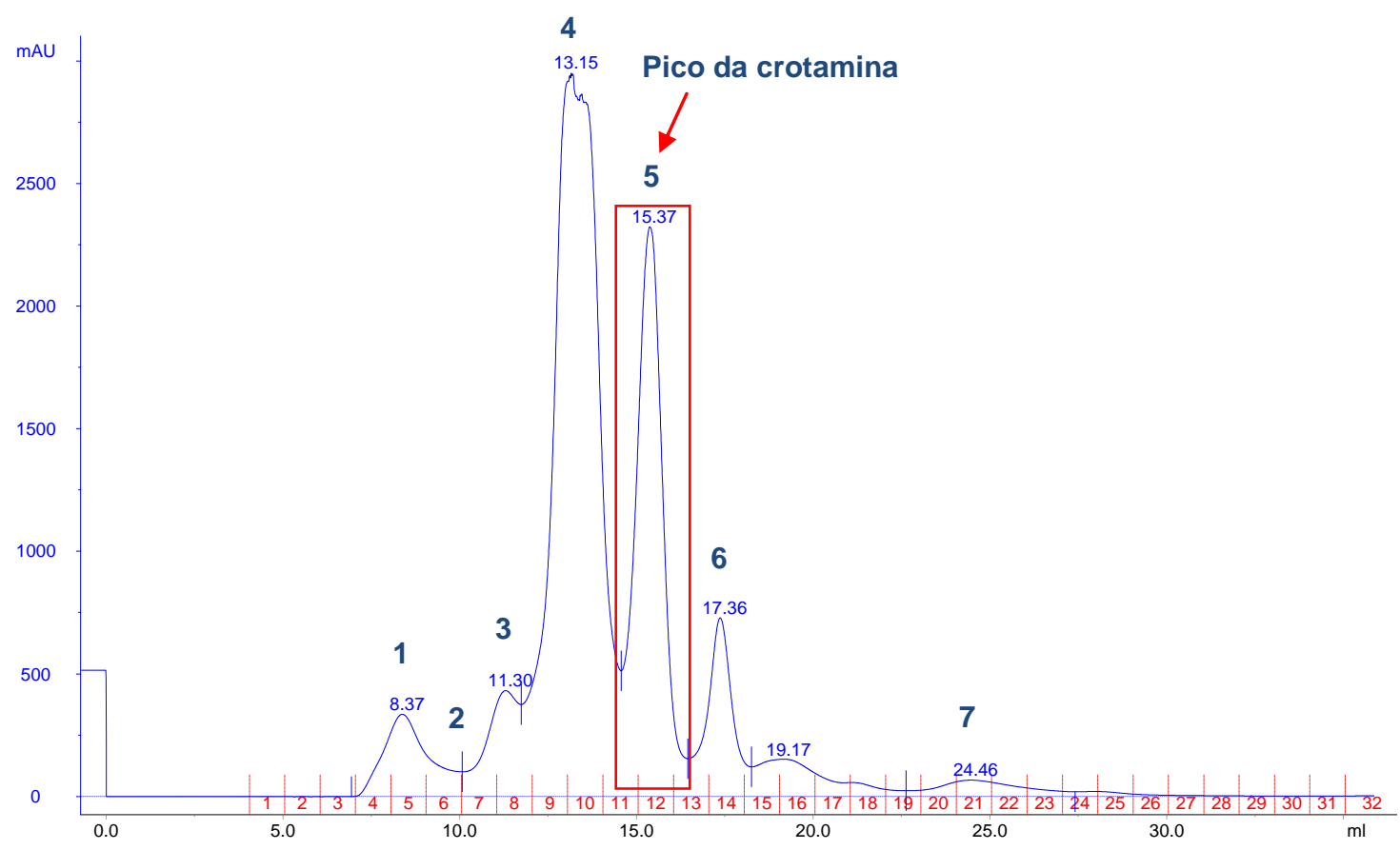

Figura 12: Cromatograma do veneno total da C.d.terrificus em coluna de exclusão molecular Superdex 75 10/300 GL. O tampão formiato de amônio, 200 mM, pH 3,0 foi utilizado para a eluição das frações. Em cada análise foram injetados $10 \mathrm{mg}$ de veneno total dissolvido em 600 $\mu \mathrm{L}$ de tampão formiato de amônio. Os picos correspondem à convulxina (pico 1), delta-toxina (pico 2), giroxina (pico 3), crotoxina (pico 4), crotamina (pico 5 indicado pela seta), analgésico (pico 6) e tripeptídeos (pico 7).

A Figura 13 ilustra o segundo passo cromatográfico para o fracionamento da crotamina (pico 5 da Figura 12), em coluna de troca catiônica do tipo Mono S. O gradiente linear de $\mathrm{NaCl}$ utilizado para eluição da fração de interesse variou de 0 a $2 \mathrm{M}$. $\mathrm{O}$ ombro observado no pico correspondente à crotamina (destacado em vermelho), indica, provavelmete, a presença de isoformas para esta toxina (Toyama e cols., 2000). 


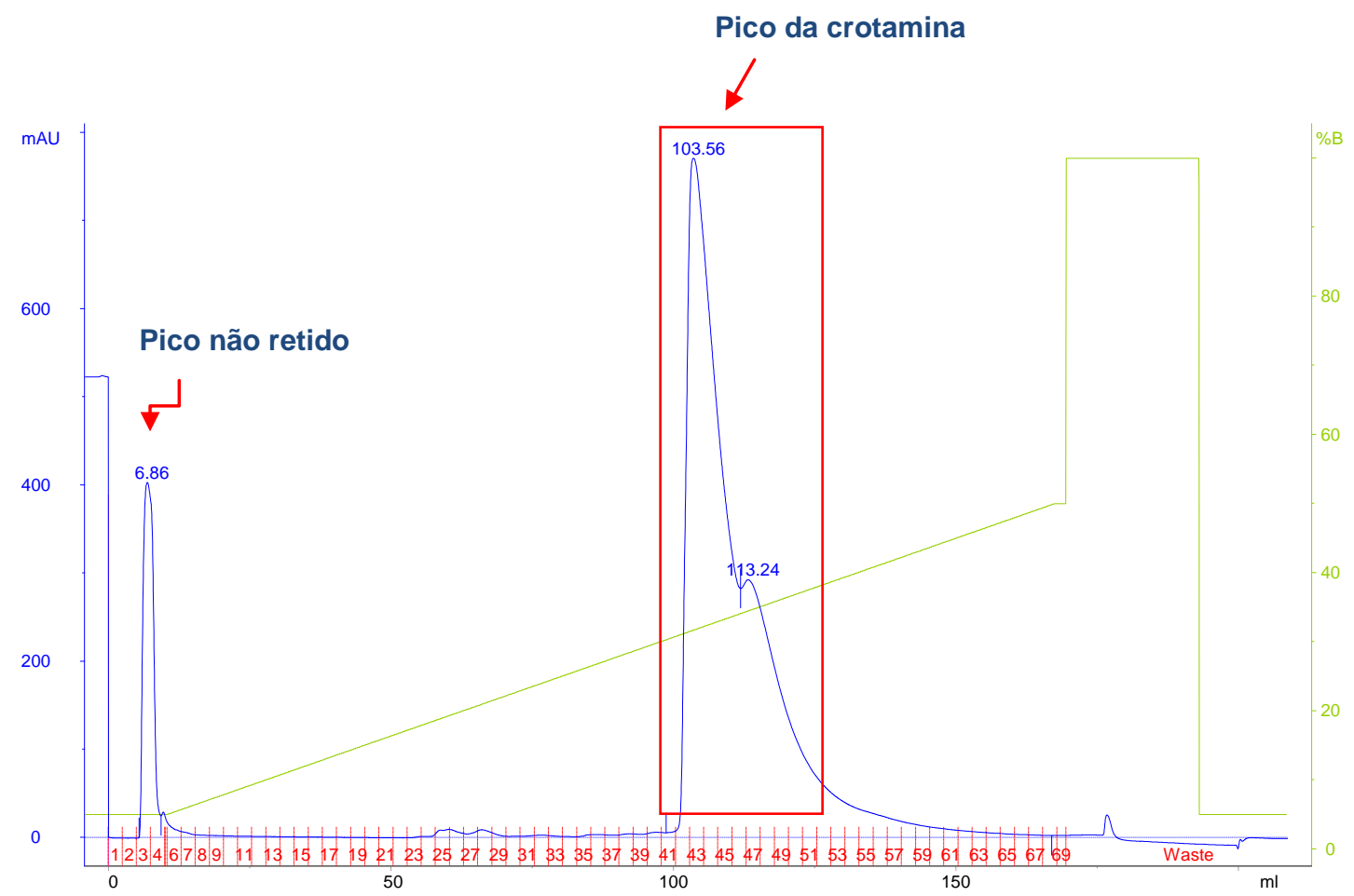

Figura 13: Recromatografia da crotamina em coluna de troca catiônica (Mono S). Utilizou-se tampão fosfato de sódio, $50 \mathrm{mM}, \mathrm{pH} 7,8$. O gradiente linear de $\mathrm{NaCl}$ variou de 0 a 2M.

Após cada etapa cromatográfica, foi realizada uma cromatografia analítica em coluna de gel filtração (Superdex 75 10/300 GL) com o objetivo de avaliar o grau de pureza da amostra de interesse. Assim, foram coletados 200 $\mu \mathrm{L}$ de crotamina nativa após a primeira e a segunda etapa cromatográfica para estudo analítico.

A Figura 14 refere-se à técnica de gel filtração analítica da fração correspondente à crotamina oriunda da primeira etapa de fracionamento. Podese observar que o volume de eluição $(15,29 \mathrm{~mL})$ ficou muito próximo daquele obtido na Figura $12(15,37 \mathrm{~mL})$, confirmando assim que o pico majoritário corresponde à toxina de interesse. Por meio da integral do perfil cromatográfico foi possível verificar que o pico correspondente à crotamina representou aproximadamente $89 \%$ da área total. Foi notória a presença de outros componentes nesse pool referente à crotamina e, portanto, se fez necessária mais uma etapa de fracionamento. 


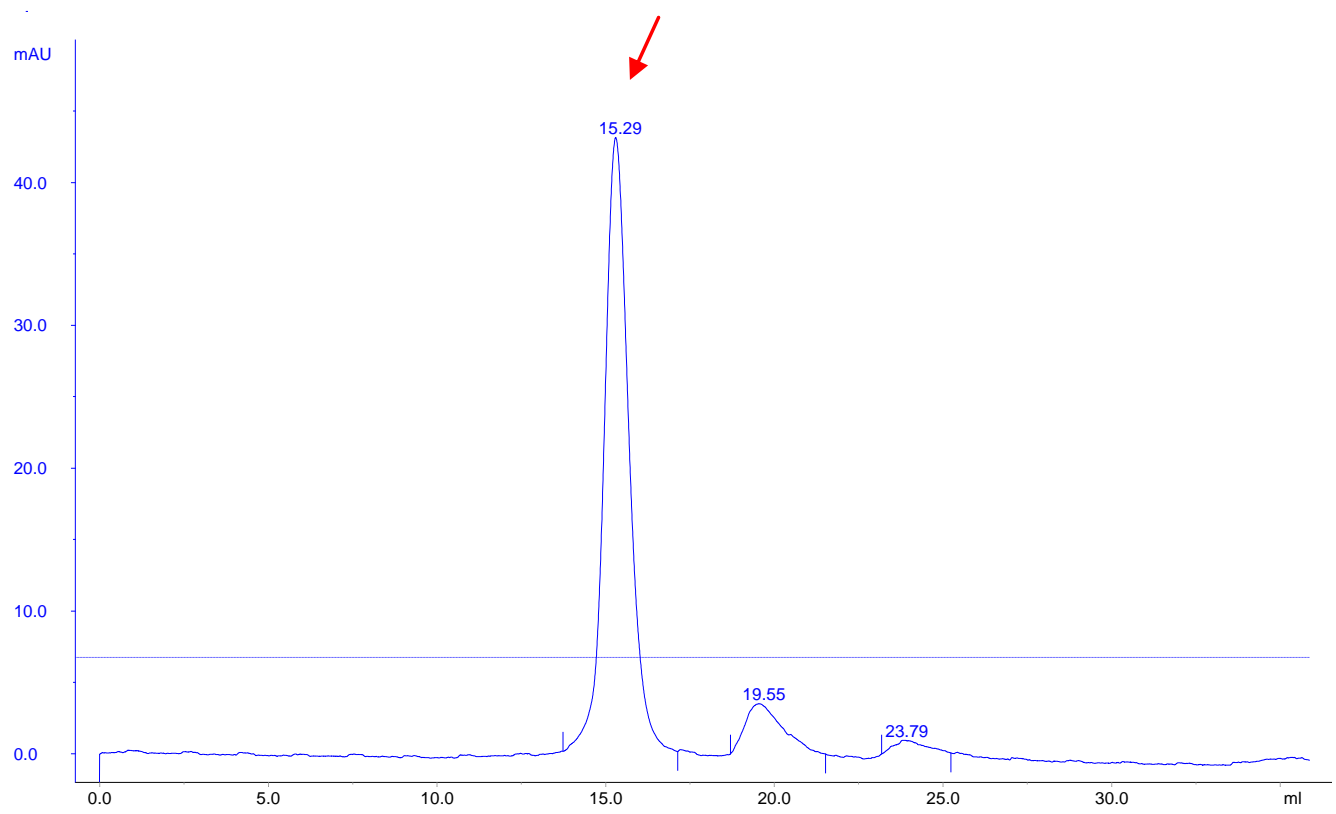

Figura 14: Perfil cromatográfico da gel filtração analítica da fração correspondente à crotamina oriunda da primeira etapa de fracionamento (Figura 12). A coluna Superdex 75 10/300 GL (24 $\mathrm{mL}$ ) foi ambientada em tampão formiato, $200 \mathrm{mM}, \mathrm{pH} 3,0$. O volume aplicado foi de $200 \mu \mathrm{L}$. A seta indica o pico corresponde à crotamina.

Na Figura 15 está representado o cromatograma da gel filtração analítica da crotamina após a segunda etapa de isolamento. Como esperado, o pico correspondente à toxina foi eluído em volume muito próximo daquele obtido na primeira etapa de isolamento $(15,07 \mathrm{~mL})$. Nesse caso a integral do perfil cromatográfico mostrou que o pico da crotamina representou $98 \%$ do cromatograma total, indicando, portanto, que a crotamina foi isolada de forma efetiva para o propósito deste trabalho. 


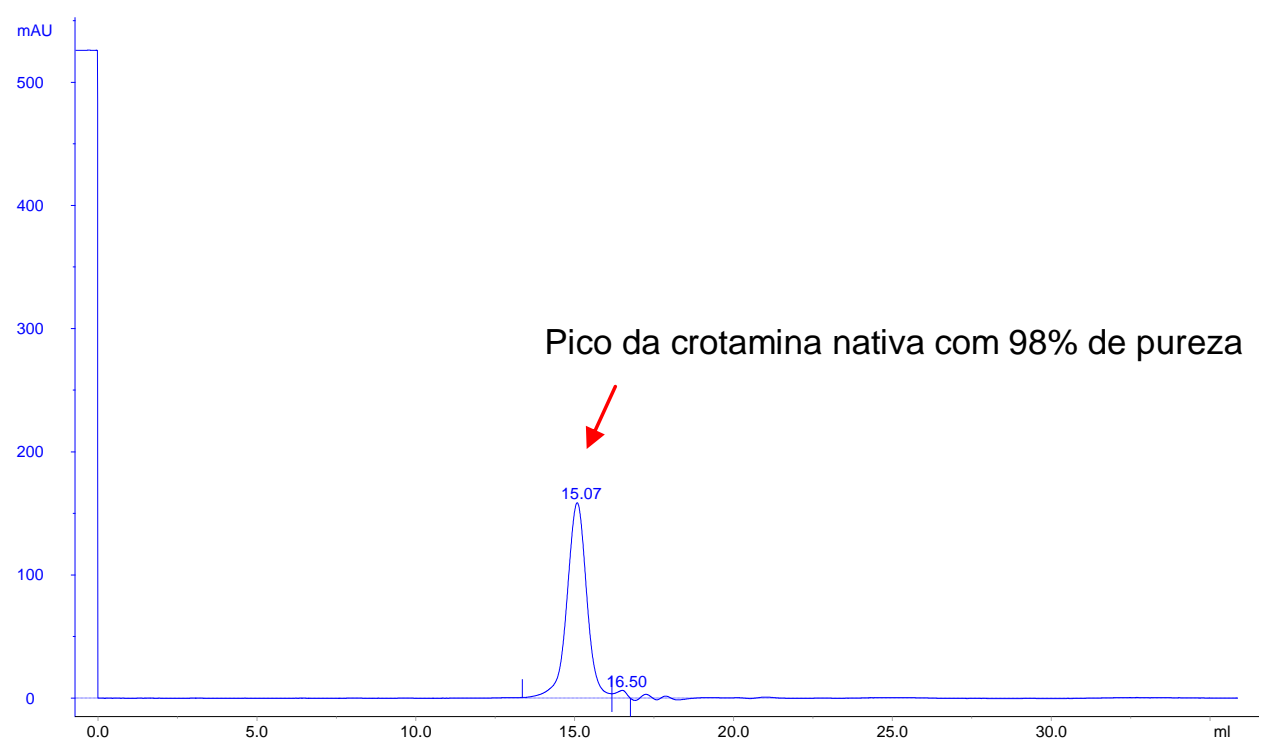

Figura 15: Perfil cromatográfico da gel filtração analítica da fração correspondente à crotamina após a segunda etapa de isolamento (Figura 13). A coluna Superdex 75 10/300 GL (24 mL) foi ambientada em tampão formiato de amônio, 200 mM, pH 3,0. O volume aplicado foi de $200 \mu \mathrm{L}$. A seta indica o pico corresponde à crotamina.

A Figura 16 ilustra a cromatografia realizada com a crotamina após o processo de irradiação (foram aplicados $200 \mu \mathrm{L}$ de amostra). É possível observar que ocorreu a formação de componentes de maior volume hidrostático, uma vez que foram identificados picos disformes em volume de eluição menor do que aquele observado para a crotamina eluída no volume de 15,19 mL. Além disso, o pico da absorvância para a amostra nativa ficou em torno de $150 \mathrm{mAu}$ (Figura 15), já para a amostra irradiada, o pico ficou abaixo de $50 \mathrm{mAu}$, o que pode sugerir a diminuição da quantidade de proteína em sua forma íntegra. Nota-se ainda que o pico da crotamina apresentou certa deformidade se comparado com o pico obtido na Figura 15, ou seja, antes do processo de irradiação. 


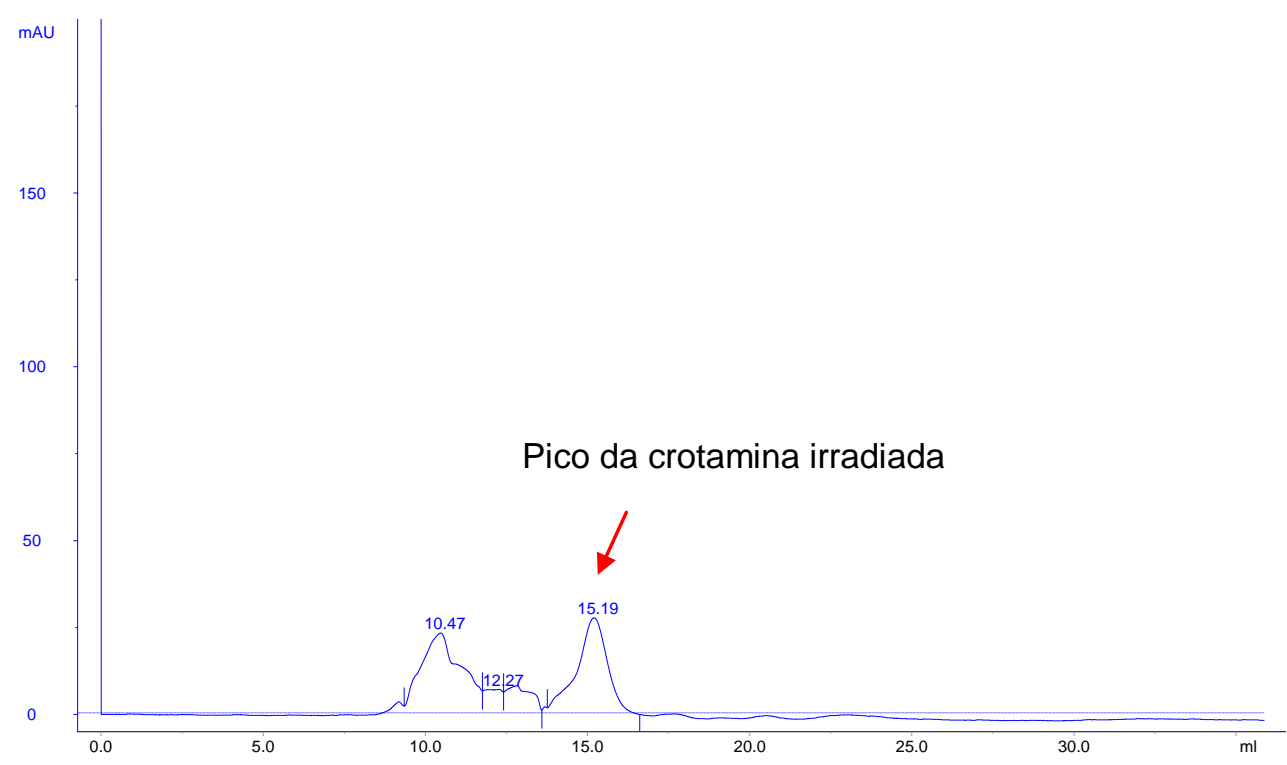

Figura 16: Perfil cromatográfico da gel filtração analítica da fração correspondente à crotamina após o processo de irradiação. A coluna Superdex 75 10/300 GL (24 mL) foi ambientada em tampão formiato de amônio, $200 \mathrm{mM}, \mathrm{pH}$ 3,0. O volume aplicado foi de $200 \mu \mathrm{L}$. A seta indica o pico corresponde à crotamina irradiada.

Na Figura 17 está ilustrado o perfil cromatográfico da técnica de alta eficiência RP-HPLC. Tal experimento foi realizado com o objetivo de comparar o perfil de isolamento da crotamina cedida pelo CEVAP com o da crotamina isolada em nosso laboratório, a partir de veneno bruto fornecido pelo Instituto Butantan, para que assim eliminássemos dúvidas em relação à presença de contaminantes na amostra proveniente do CEVAP. Para efetuar tal análise foram realizadas quatro corridas cromatográficas. Na primeira etapa aplicou-se à coluna cromatográfica Vydac C-8 uma solução tampão que foi utilizada como o branco (linha preta). Em seguida foi aplicado à coluna o veneno total da C.d.terrificus, cujo perfil está representado pela linha verde. $O$ perfil obtido nesse caso mostrou dois picos distintos. Na terceira análise a toxina isolada proveniente do veneno total do Instituto Butantan foi injetada na coluna de fase reversa (linha vermelha). Finalmente, a crotamina isolada do CEVAP foi aplicada à coluna e corresponde ao perfil cromatográfico representado pela cor azul.

Observou-se com tal análise que a crotamina proveniente do CEVAP apresentou um pico único e tempo de eluição correspondente àquele verificado também para a crotamina proveniente do Instituto Butantan. 


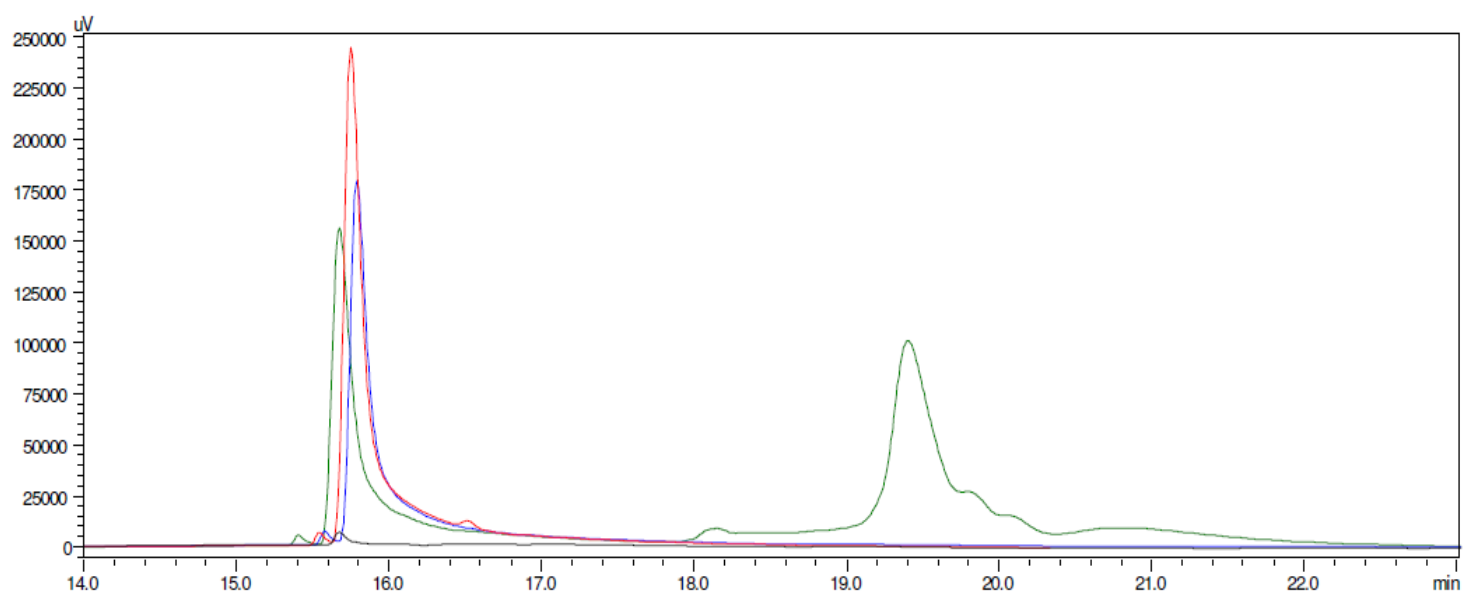

Figura 17: Cromatografia de fase reversa (RP-HPLC) comparativa em coluna Vydac C-8 realizada para verificação da crotamina cedida pelo CEVAP. Os perfis cromatográficos estão representados da seguinte maneira: solução tampão (branco) (linha preta); veneno total da C.d.terrificus (verde); crotamina isolada do veneno total proveniente do Instituto Butantan (vermelha); crotamina isolada do veneno total proveniente do CEVAP (azul).

\subsection{Eletroforese em gel de poliacrilamida (SDS-PAGE)}

$\mathrm{Na}$ Figura 18 está representado o gel de eletroforese (15\%) realizado com a crotamina nativa e irradiada, em tampão reduzido e não reduzido, utilizando a tricina como tampão de corrida. Aplicou-se na primeira coluna do gel um padrão de massa molecular conhecido.

Foi possível observar que o tampão não reduzido resultou em expressivo arraste por todo o gel de eletroforese, impedindo a visualização das bandas. Assim, o tampão reduzido possibilitou, ainda que de forma sutil, a visualização das bandas para a amostra nativa e irradiada. Aparentemente, a amostra irradiada apresentou uma banda com maior área no gel de eletroferese, indicando provável alteração em termos de massa molecular. 


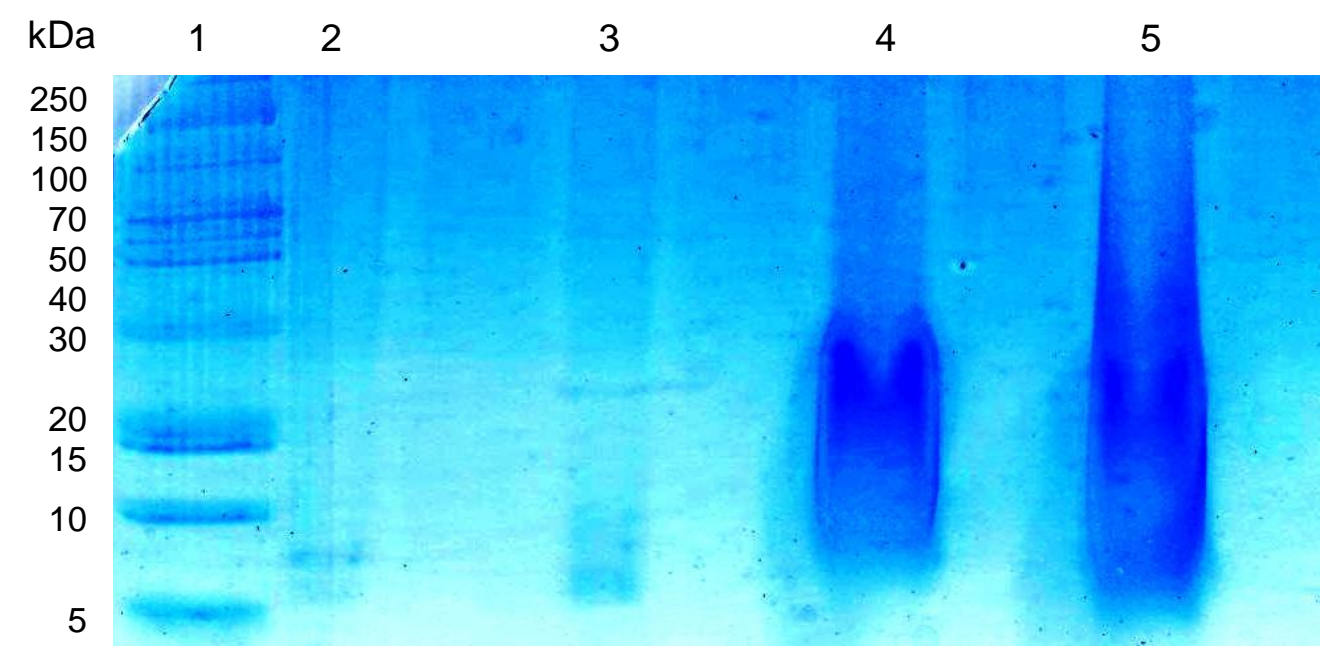

Figura 18: Gel de eletroforese (15\%) corado com Coomassie blue 250-R. O padrão de massa molecular foi aplicado na coluna 1; crotamina nativa e irradiada em tampão de amostra não reduzido (colunas 2 e 3 respectivamente); crotamina nativa e irradiada em tampão reduzido (colunas 4 e 5 respectivamente). A corrente foi fixada em $25 \mathrm{~mA}$, durante aproximadamente 90 minutos.

\subsection{Espectrometria de Massa}

A Figura 19 mostra o perfil obtido por espectrometria de massa da crotamina nativa. De acordo com os dados obtidos nesta análise e a consequente interpretação dos mesmos, foi possível identificar a formação de dois picos majoritários no espectro: uma molécula de 4884,23 \pm 1,92 Da e outra de 4740,73 $\pm 2,40$ Da. Sabe-se que a massa molecular da crotamina em seu estado nativo é de $4882 \mathrm{Da}$, portanto, a massa molecular predominante no espectro confirma a molécula de crotamina.

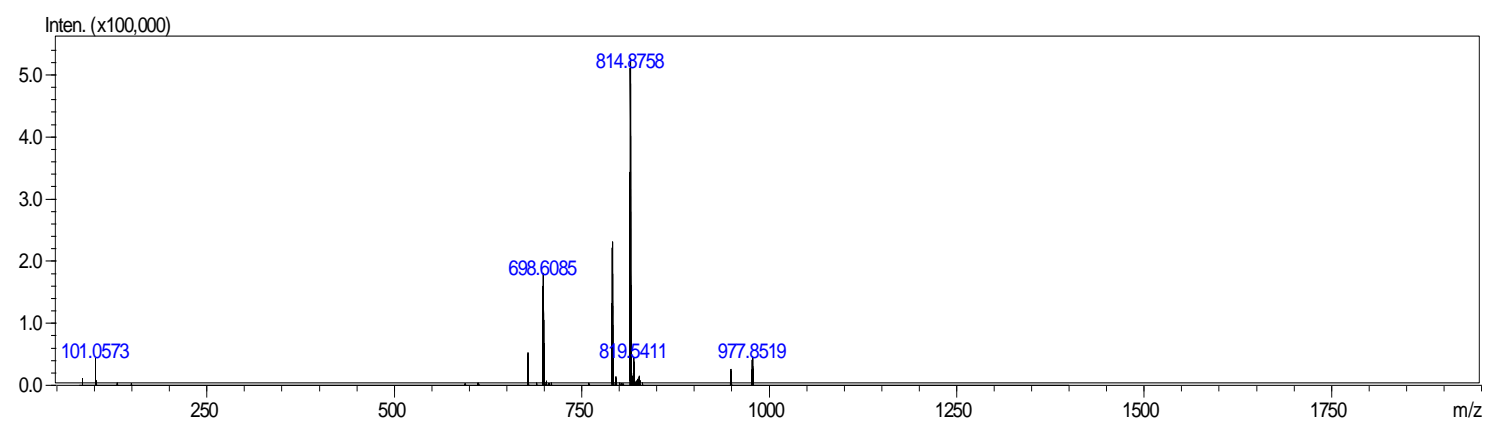

Figura 19: Espectrometria de massa da crotamina nativa em um instrumento IT-TOF. 
A Figura 20 apresenta a espectrometria de massa para a amostra irradiada. Nesse caso foi possível observar a presença de um número maior de picos ou contaminantes (dados também observados quando a amostra foi previamente aplicada em coluna de fase reversa, acoplada ao espectrômetro de massa), como uma provável consequência da quebra da proteína em peptídeos com menor massa molecular.

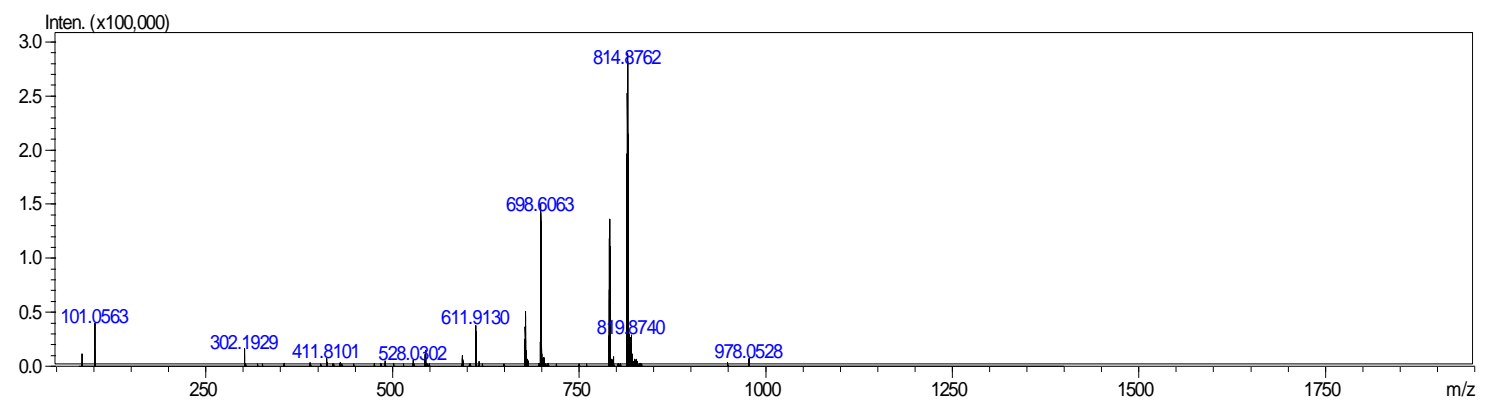

Figura 20: Espectrometria de massa da crotamina irradiada em um instrumento IT-TOF.

\subsection{Fluorescência}

$\mathrm{Na}$ Figura 21 estão apresentados os resultados da análise de fluorescência do triptofano presente na crotamina nativa e irradiada. Pode-se observar que a amostra irradiada apresentou intensidade inferior à da amostra nativa, sugerindo alteração na exposição dos fluoróforos ao solvente. Em relação ao deslocamento do pico de emissão, não houve alteração relevante, sendo que o pico máximo de emissão de fluorescência para a amostra nativa ocorreu em $358 \mathrm{~nm}$ e para a amostra irradiada em $356 \mathrm{~nm}$.

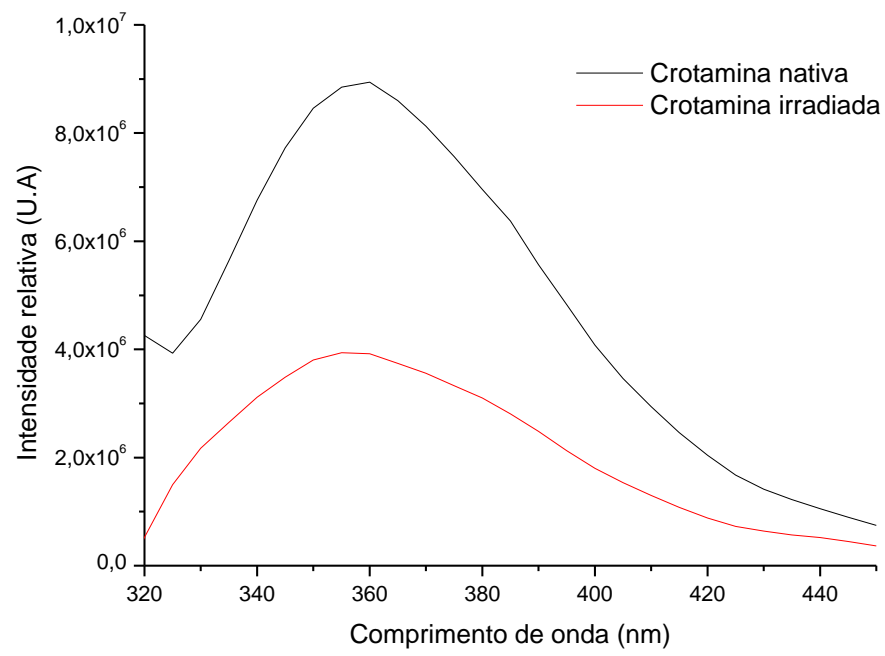

Figura 21: Intensidade relativa de fluorescência do triptofano da crotamina nativa e irradiada, ambas na concentração de $100 \mu \mathrm{g} / \mathrm{mL}$ em tampão PBS. 


\subsection{Dicroísmo Circular}

A Figura 22 ilustra a análise de dicroísmo circular da crotamina no estado nativo e irradiado à temperatura de $20{ }^{\circ} \mathrm{C}$. É possível observar alterações na estrutura secundária da proteína após irradiação, principalmente na região de transição de folha $\beta$ que compreende o intervalo de 210 a 225 nm, dentre outros. Observam-se ainda alterações relacionadas à estrutura $\alpha$-hélice nas seguintes regiões do espectro: $208-210 \mathrm{~nm}$ e $222 \mathrm{~nm}$.

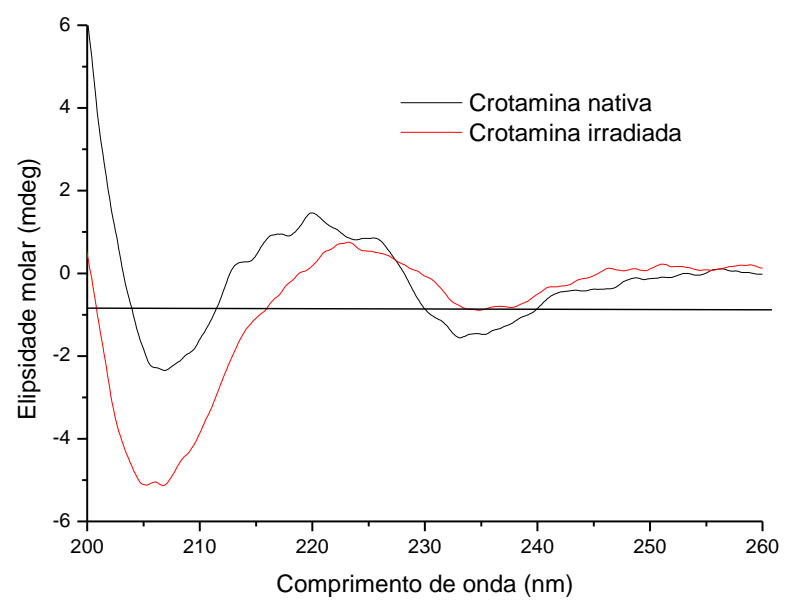

Figura 22: Análise de Dicroísmo Circular da crotamina nativa e irradiada, ambas na concentração de $100 \mu \mathrm{g} / \mathrm{mL}$ em tampão PBS.

Realizou-se também a análise da estrutura secundária da toxina, nos estados nativo e irradiado, com variação da temperatura. Assim, a cada $10^{\circ} \mathrm{C}$ de incremento obteve-se o perfil de CD. A temperatura inicial foi de $20^{\circ} \mathrm{C}$ e a temperatura final de $90^{\circ} \mathrm{C}$. Após a última leitura, a temperatura foi diminuída novamente até $20^{\circ} \mathrm{C}$ e novo espectro foi obtido. Os gráficos da Figura 23 ilustram os perfis obtidos a cada mudança de temperatura para a crotamina nativa e irradiada. De acordo com os resultados obtidos, verificou-se que o aquecimento gradual da proteína alterou o espectro relativo à estrutura secundária da crotamina, tanto para a amostra nativa, quanto para a irradiada, sendo que em $90^{\circ} \mathrm{C}$, os perfis obtidos para ambas as proteínas ficaram muito semelhantes, sugerindo completa desnaturação. Observou-se ainda que 0 último perfil obtido (I), em $20^{\circ} \mathrm{C}$ após aquecimento apresentou recuperação parcial da estrutura secundária. 

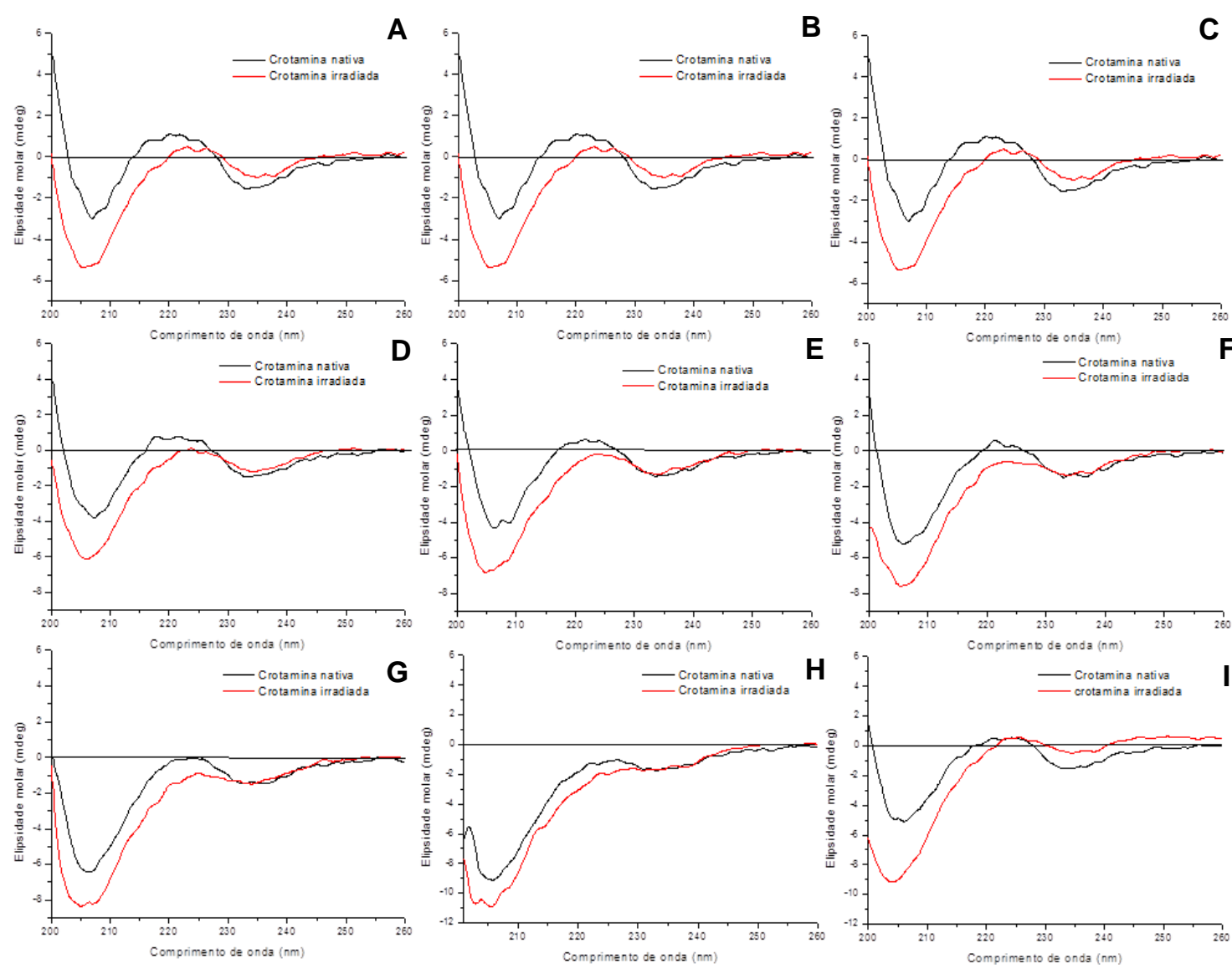

Figura 23: Análise de Dicroísmo Circular da crotamina nativa e irradiada, ambas na concentração de $100 \mu \mathrm{g} / \mathrm{mL}$ em tampão PBS. A: perfil correspondente à temperatura de $20^{\circ} \mathrm{C}$. B: perfil corresponde à temperatura de $30^{\circ} \mathrm{C}$. C: perfil correspondente à temperatura de $40^{\circ} \mathrm{C}$. D: perfil correspondente à temperatura de $50^{\circ} \mathrm{C}$. E: perfil correspondente à temperatura de $60^{\circ} \mathrm{C}$. F: perfil correspondente à temperatura de $70^{\circ} \mathrm{C}$. G: perfil correspondente à temperatura de $80^{\circ} \mathrm{C}$. H: perfil correspondente à temperatura de $90^{\circ} \mathrm{C}$. I: Perfil correspondente à temperatura de $20^{\circ} \mathrm{C}$ após aquecimento.

Ainda em relação aos dados obtidos com a técnica de CD foi possível observar as alterações conformacionais para cada estado da crotamina, nativo e irradiado (dados já apresentados na Figura 22), de acordo com a variação de temperatura, sendo que as mesmas condições citadas anteriormente foram mantidas (temperatura inicial de $20^{\circ} \mathrm{C}$ e a final de $90^{\circ} \mathrm{C}$, com incremento de $10^{\circ} \mathrm{C}$ ). A última análise representa a temperatura de $20^{\circ} \mathrm{C}$ após a desnaturação por aquecimento (Figura 24). Assim, ficaram evidentes as mudanças conformacionais na estrutura secundária da crotamina, sendo que a cada aumento de temperatura, foram registradas pequenas alterações que 
culminaram na completa desnaturação em $90^{\circ} \mathrm{C}$. Novamente pode-se observar após a compelta desnaturação, que a toxina apresentou perfil semelhante àqueles obtidos nas temperaturas de 70 e $80^{\circ} \mathrm{C}$.
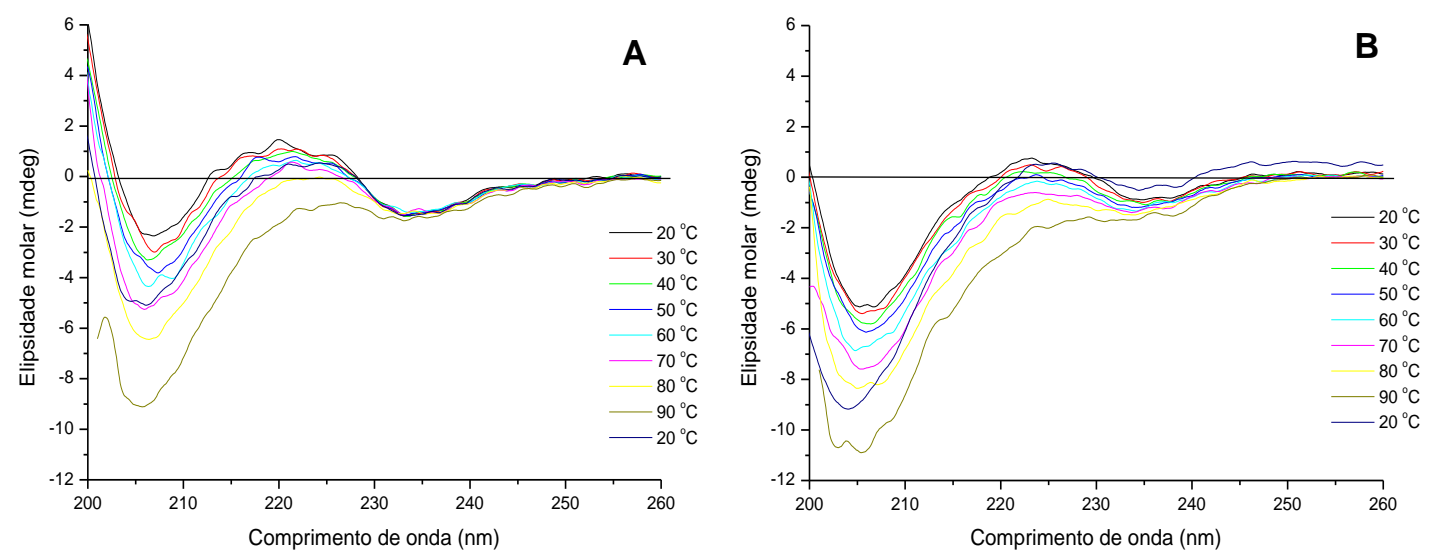

Figura 24: Análise de Dicroísmo Circular da crotamina nativa e irradiada, ambas na concentração de $100 \mu \mathrm{g} / \mathrm{mL}$ em tampão PBS. A: perfil correspondente à alteração estrutural causada pela variação da temperatura para a crotamina nativa. B: perfil corresponde à alteração estrutural causada pela variação da temperatura para a crotamina irradiada.

\subsection{Microscopia de Força Atômica}

A Figura 25 ilustra a imagem da superfície de mica com amostra de crotamina nativa na concentração de $0,1 \mu \mathrm{g} / \mathrm{mL}$. Pode-se observar que há regiões com estruturas totalmente diferenciáveis, onde é possível identificar "cadeias" arredondadas bem definidas. Sabe-se que a superfície de mica é extremamente flat, assim, ainda fica evidente na imagem a presença de espaços totalmente livres, ou seja, onde não ocorreu a adsorção da toxina. 


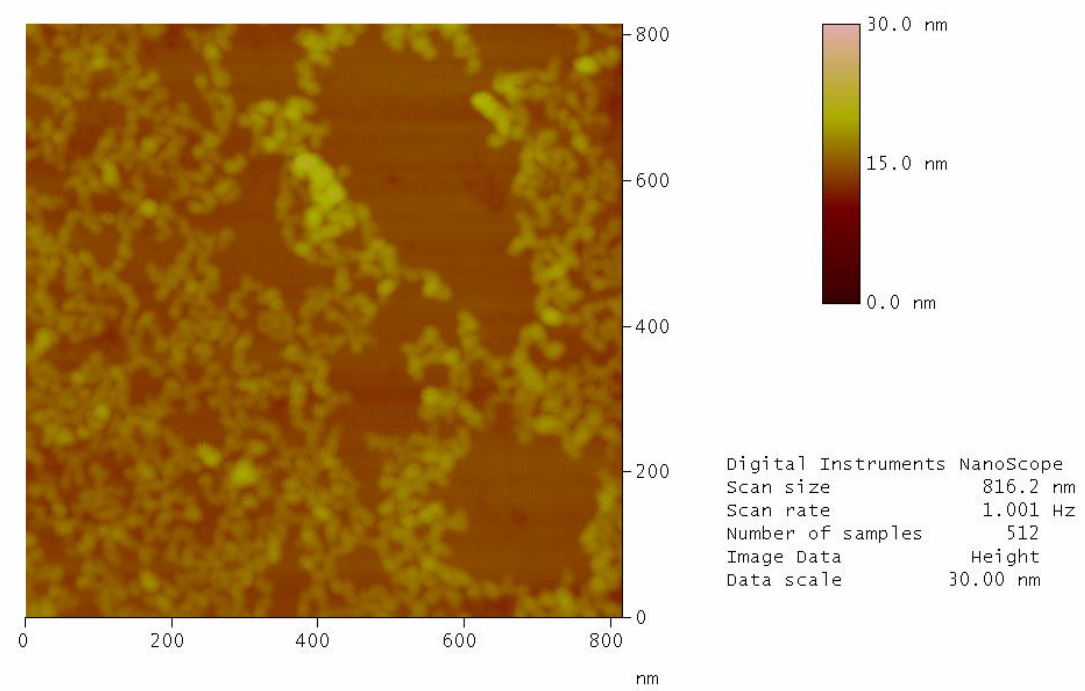

$10101303.00 \mathrm{p}$

Figura 25: Imagem obtida pela técnica de Tapping Mode, de uma amostra em solução da crotamina nativa, em concentração de $0,1 \mu \mathrm{g} / \mathrm{mL}$, adsorvida em superfície de mica (scan size de $816 \mathrm{~nm}$; pontos por linha: 512).

A Figura 26 ilustra a imagem em 3D da Figura 25. Talvez por essa imagem fiquem mais nítidas regiões da mica em que se é possível observar a ausência de proteína adsorvida.

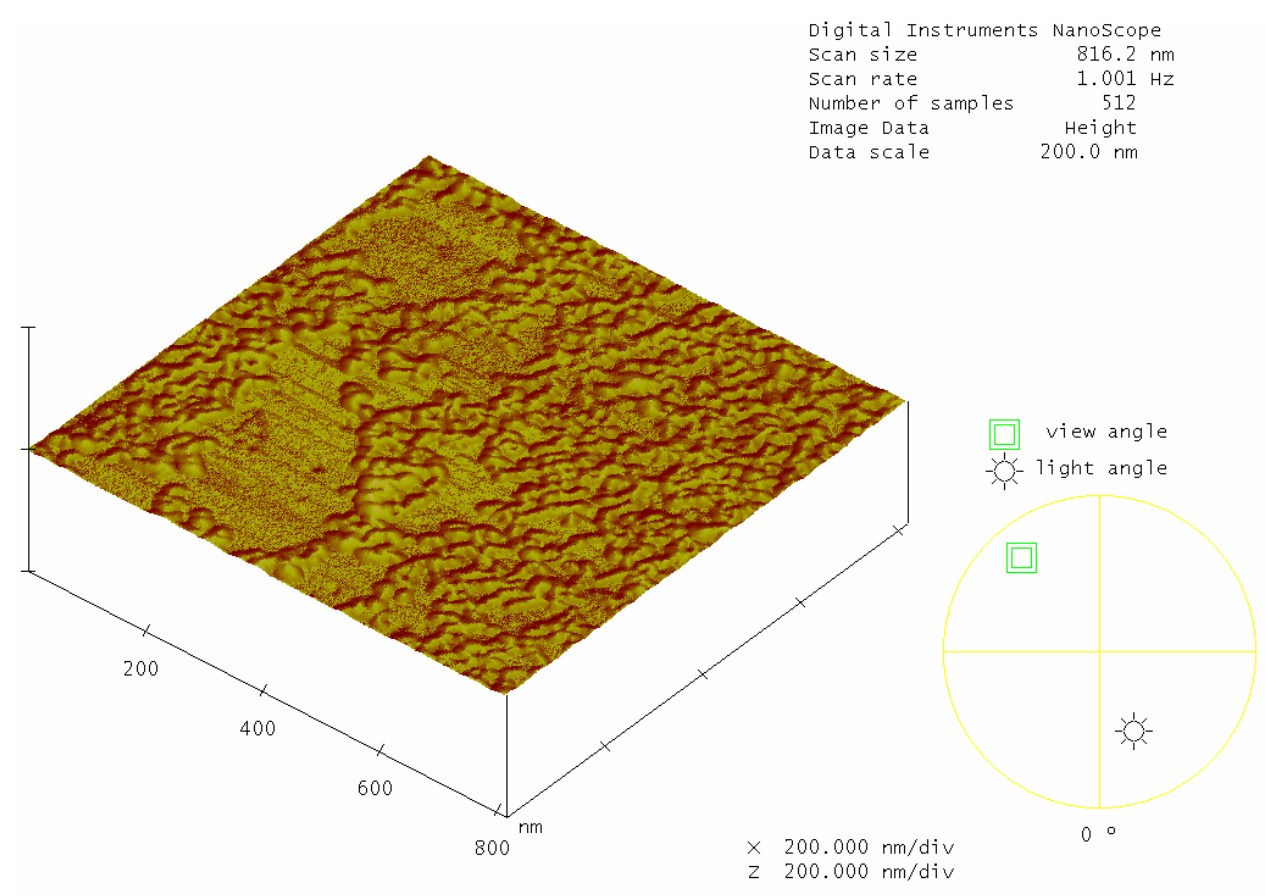

$10101303.00 \mathrm{p}$

Figura 26: Imagem em 3D representativa da crotamina nativa na concentração de $0,1 \mu \mathrm{g} / \mathrm{mL}$. 
A Figura 27 ilustra uma imagem obtida da amostra de crotamina irradiada. Nesse caso foi possível perceber que a toxina preencheu toda a superfície de mica. Em comparação com a imagem da crotamina nativa, não se observou estruturas bem definidas. Cabe ressaltar que o scan size desta imagem foi de $816 \mathrm{~nm}$.

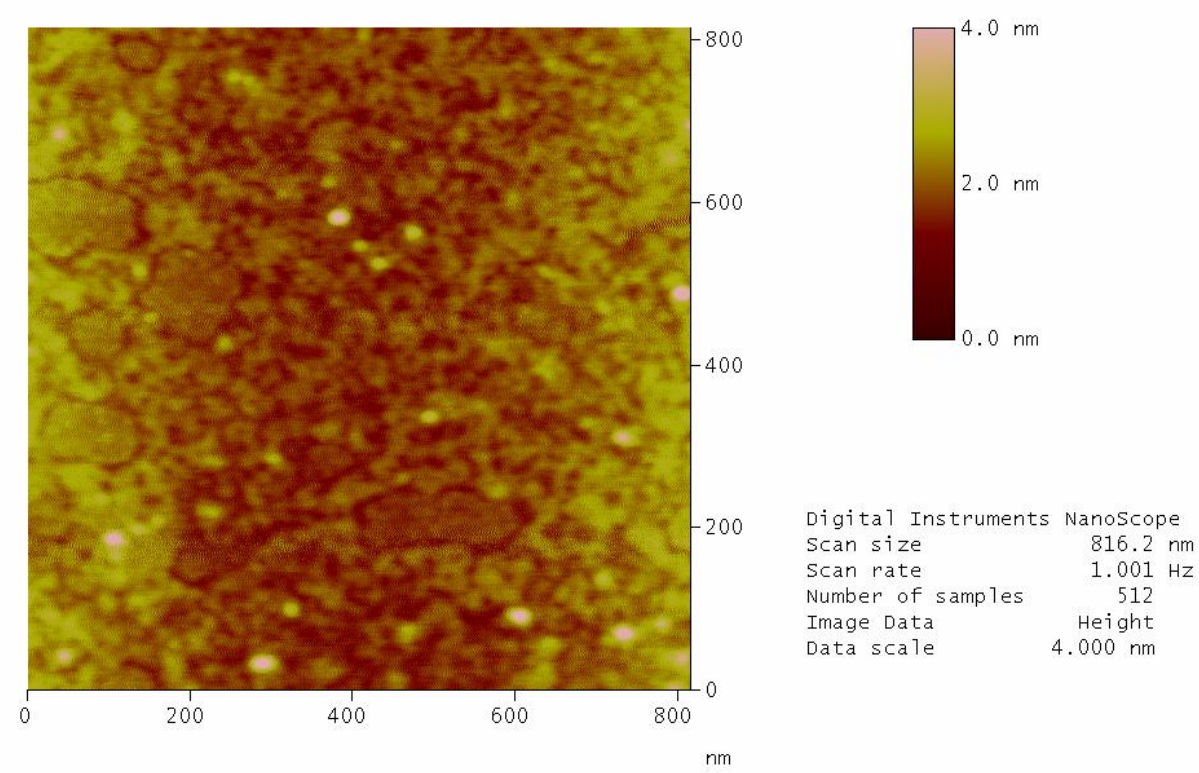

$10101143.00 p$

Figura 27: Imagem obtida pela técnica de Tapping Mode, de uma amostra em solução da crotamina irradiada, em concentração de $0,1 \mu \mathrm{g} / \mathrm{mL}$, adsorvida em superfície de mica (scan size de $816 \mathrm{~nm}$; pontos por linha: 512).

A partir da imagem em 3D (Figura 28), pode-se mais uma vez notar que toda a superfície de mica está completamente coberta pela amostra de crotamina irradiada. 


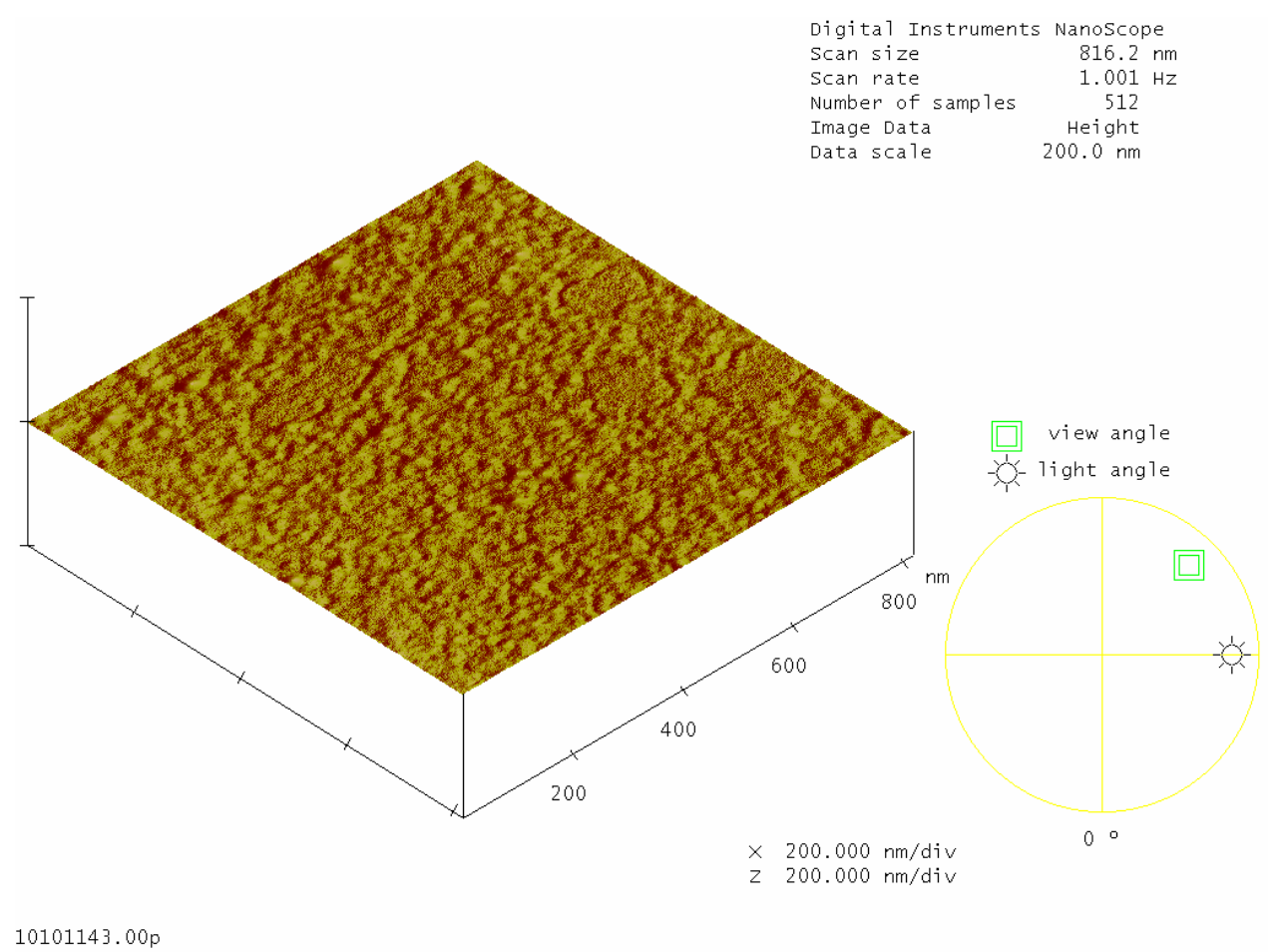

Figura 28: Imagem em 3D da amostra de crotamina irradiada, na concentração de $0,1 \mu \mathrm{g} / \mathrm{mL}$.

\subsection{Alta Pressão Hidrostática}

A Figura 29 ilustra os dados de fluorescência obtidos a partir de variações na pressão hidrostática para a amostra nativa e irradiada. No primeiro momento foi realizada uma análise em termos de pressões decrescentes (3,2,1 kbar e pressão atmosférica). Foi possível observar que o espectro de fluorescência apresentou algumas modificações em termos de intensidade relativa de acordo com a variação de pressão e tais alterações foram mais proeminentes na crotamina nativa (A). Mudanças relativas ao deslocamento do perfil fluorimétrico não foram observadas para as pressões estudadas.

De acordo com os dados obtidos foi possível verificar que, aparentemente, a intensidade de fluorescência aumentou com a diminuição da pressão, tanto para a amostra nativa $(\mathbf{A})$, quanto para a irradiada (B), porém, em comparação com a nativa, a crotamina irradiada apresentou uma diminuição mais expressiva da intensidade de fluorescência sob alta pressão, confirmando alterações estruturais importantes provocadas pela radiação. 

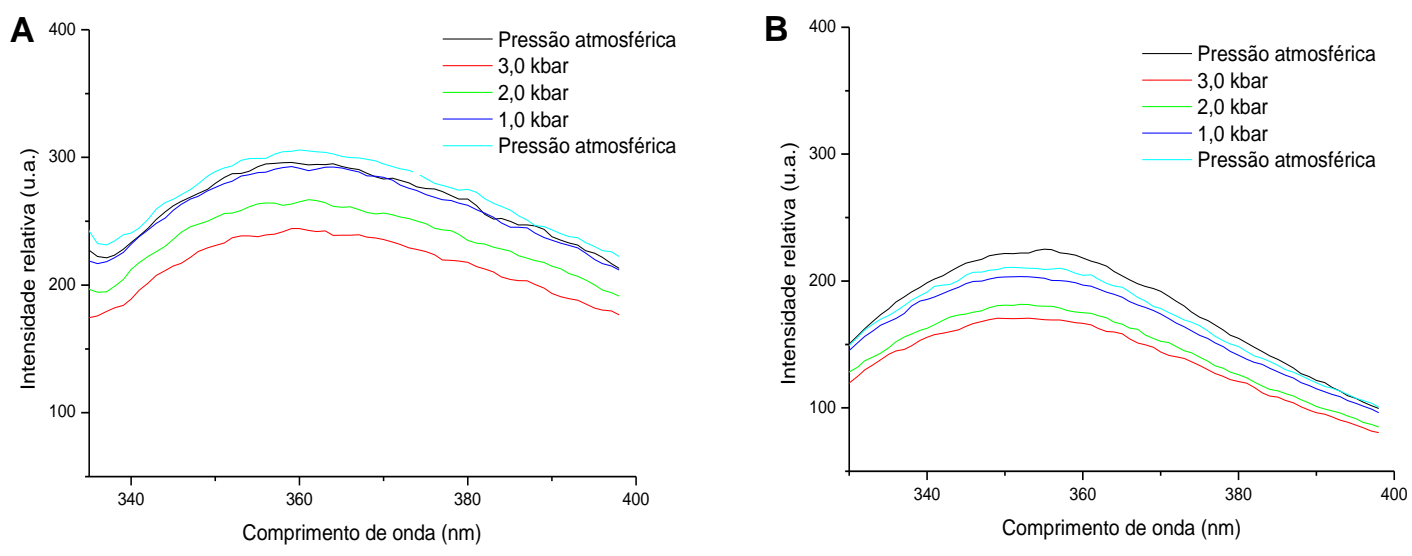

Figura 29: Espectro de fluorescência, sob alta pressão hidrostática, da crotamina nativa e irradiada, ambas na concentração de $20 \mu \mathrm{g} / \mathrm{mL}$ em tampão TRIS. A: perfil correspondente à leitura de fluorescência em decorrência da variação decrescente de pressão para a crotamina nativa. B: perfil corresponde à leitura de fluorescência em decorrência da variação decrescente de pressão para a crotamina irradiada.

A Tabela 3 ilustra os valores do pico de intensidade de fluorescência, para ambas as amostras, em cada variação de pressão a qual a crotamina foi submetida neste teste.

Tabela 3: Valores de intensidade de fluorescência do triptofano para os diferentes valores de pressão.

\begin{tabular}{c|cc}
\hline \multirow{2}{*}{ Pressão } & \multicolumn{2}{|c}{ Intensidade de fluorescência (u.a) } \\
\cline { 2 - 3 } & Nativa & Irradiada \\
\hline Pressão atmosférica & 295 & 225 \\
3 kbar & 245 & 171 \\
2 kbar & 263 & 182 \\
1 kbar & 292 & 201 \\
\hline
\end{tabular}


Em um segundo momento realizou-se novo teste com a crotamina irradiada considerando a mudança crescente da pressão (Figura 30), dessa forma iniciou-se a leitura de fluorescência em pressão atmosférica, em seguida a pressão foi elevada a $1 \mathrm{kbar}, 2 \mathrm{kbar}$ e $3 \mathrm{kbar}$. Novamente não se observaram mudanças significativas em termos de intensidade de fluorescência medida.

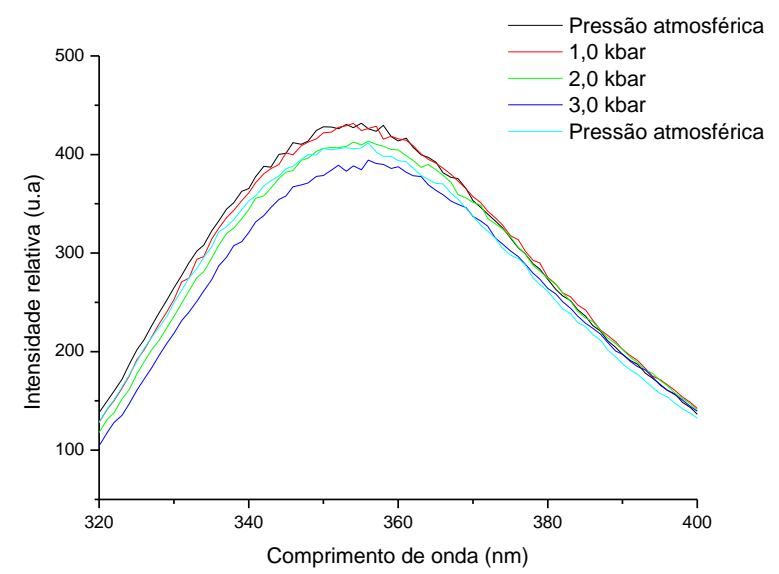

Figura 30: Espectro de fluorescência, sob alta pressão hidrostática, da crotamina irradiada na concentração de $20 \mathrm{\mu g} / \mathrm{mL}$ em tampão TRIS. Perfil correspondente à leitura de fluorescência em decorrência da variação crescente de pressão para a crotamina irradiada.

\subsection{Teste de desnaturação}

As figuras que serão apresentadas a seguir mostram incialmente a ação da guanidina a cada leitura de fluorescência (1, 2, 3 e 24 horas) realizada para as diferentes concentrações de guanidina $(0,5,1,0,1,5,2,0,3,0,4,0,5,0$ e $6,0 \mathrm{M})$.

A Figura 31 ilustra a leitura de fluorescência do triptofano presente na crotamina nativa (A) e irradiada (B), ambas em $0,5 \mathrm{M}$ de guanidina. É possível observar que nesta molaridade a guanidina já causou alterações significativas quanto à intensidade de fluorescência. Para a amostra nativa observou-se uma queda gradual da intensidade de fluorescência com o passar das horas, sendo que após 24 horas de observação a intensidade de fluorescência foi cerca de $70 \%$ menor do que em relação ao controle (crotamina nativa na ausência de guanidina). Para a amostra irradiada, após as três primeiras horas de observação a crotamina apresentou maior intensidade de fluorescência em relação ao controle (crotamina irradiada na ausência de 
guanidina). Apenas após 24 horas que a intensidade de fluorescência foi menor do que o controle.

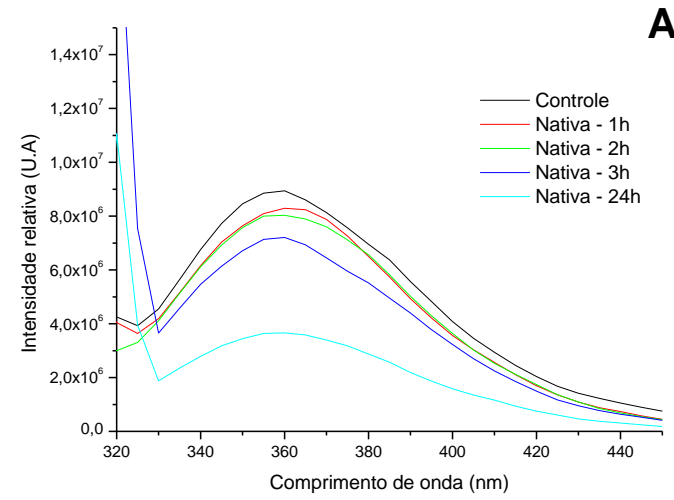

A

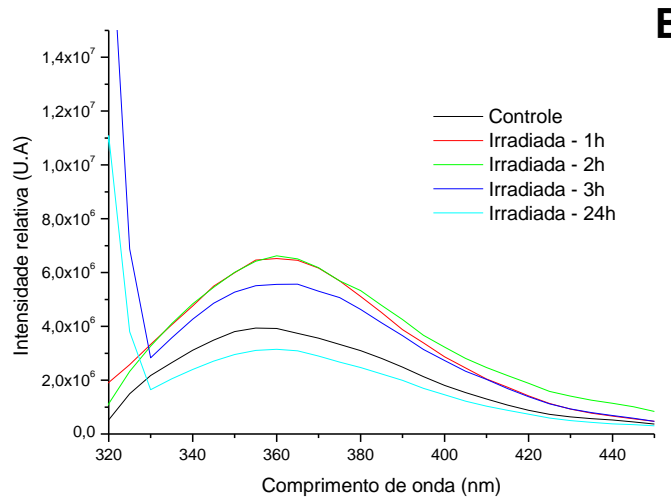

B

Figura 31: Espectro de fluorescência do triptofano presente na crotamina nativa (A) e irradiada (B) em 0,5 M de guanidina.

A Figura 32 mostra a análise de fluorescência do triptofano presente na crotamina em 1,0 M de guanidina. Pode-se observar que, tanto o perfil da amostra nativa quanto o da amostra irradiada apresentaram comportamento semelhante àquele analisado na Figura 31 (A e B) respectivamente, mostrando que tal variação na molaridade do agente desnaturante não representou alterações significativas na intensidade de fluorescência.
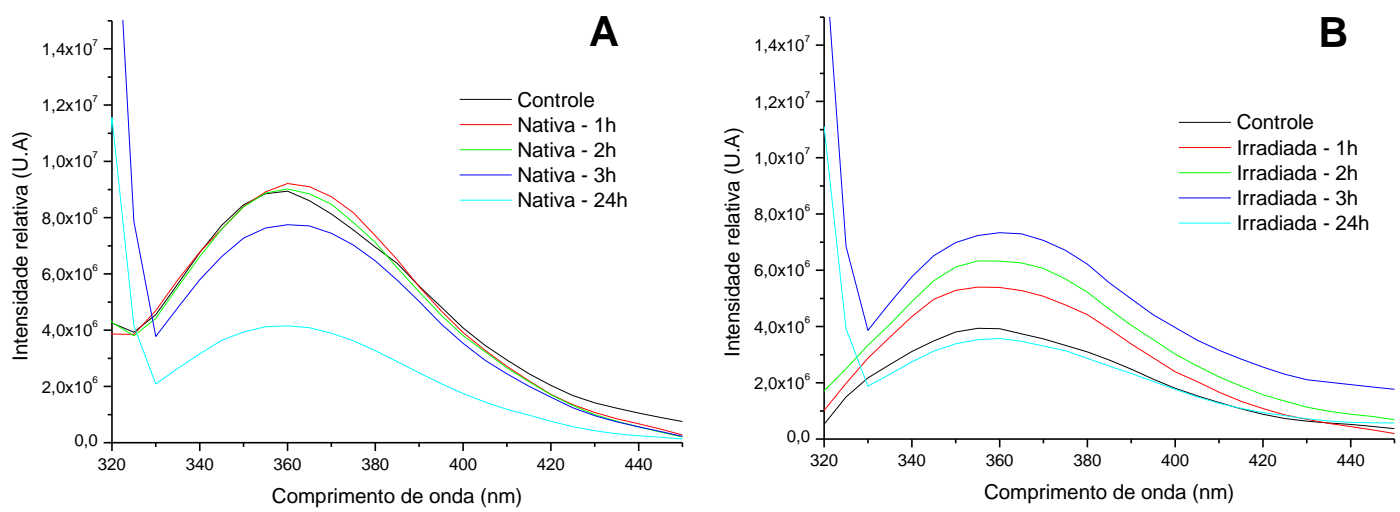

Figura 32: Espectro de fluorescência do triptofano presente na crotamina nativa (A) e irradiada (B) em 1,0 M de guanidina.

A Figura 33 apresenta a análise de fluorescência do triptofano da crotamina em 1,5 M de guanidina. Novamente observam-se alterações no perfil de fluorescência, principalmente para a amostra nativa. Aparentemente a desnaturação na primeira hora aumentou a intensidade de fluorescência da crotamina em relação ao controle. Fato semelhante aconteceu com a amostra 
irradiada. Nesse caso a intensidade de fluorescência só não foi maior que o controle após 24 horas de observação.
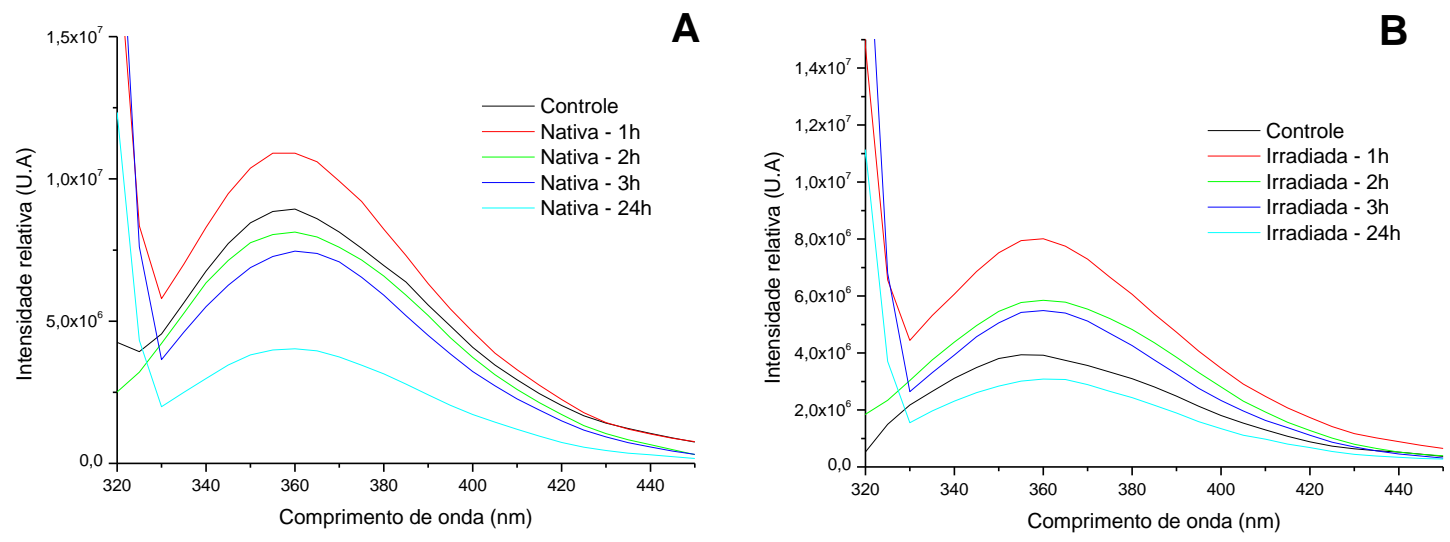

Figura 33: Espectro de fluorescência do triptofano presente na crotamina nativa $(\mathbf{A})$ e irradiada (B) em 1,5 M de guanidina.

A Figura 34 mostra a análise de fluorescência do triptofano da crotamina em 2,0 M de guanidina. A tendência de alterações na intensidade de fluorescência tanto para a amostra nativa como para a irradiada mostra-se evidente, uma vez que quanto maior a molaridade do agente desnaturante, maior a variação observada.
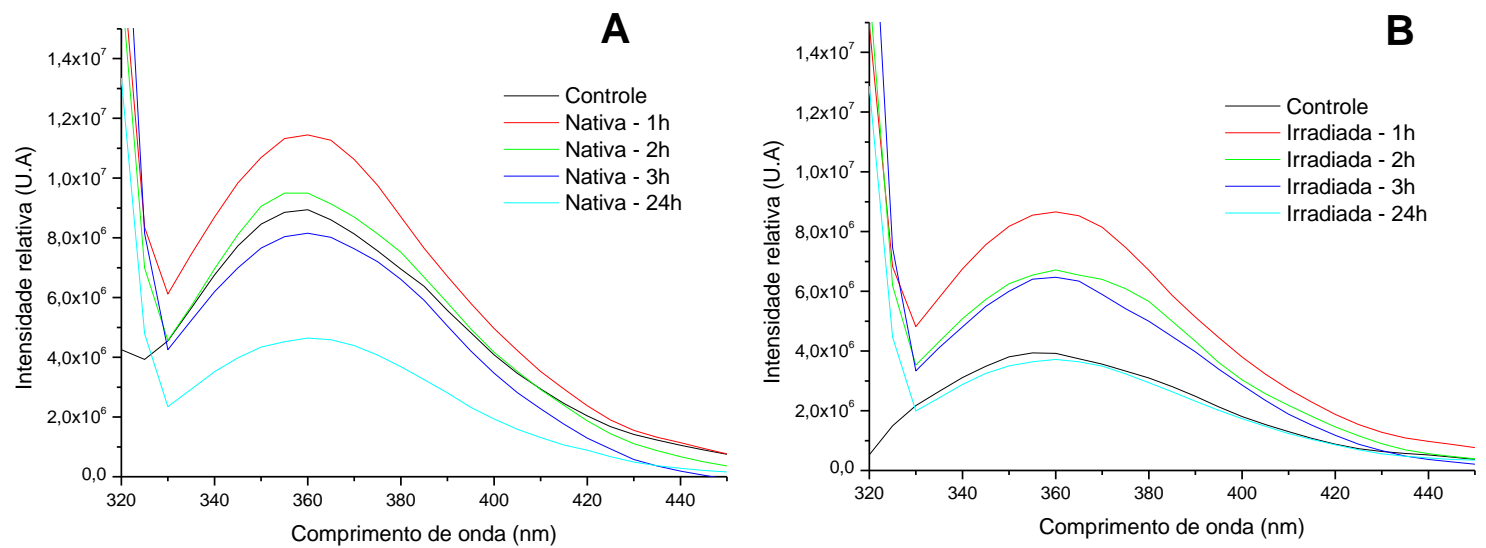

Figura 34: Espectro de fluorescência do triptofano presente na crotamina nativa $(\mathbf{A})$ e irradiada (B) em 2,0 M de guanidina.

A Figura 35 apresenta a análise de fluorescência do triptofano da crotamina em 3,0 M de guanidina. A amostra de crotamina nativa e irradiada apresentaram variações semelhantes àquelas observadas na Figura 34 (A e B) respectivamente, sugerindo que, aparentemente, tal molaridade de 
guanidina não implica em mudanças significativas em relação à concentração de $2 \mathrm{M}$.
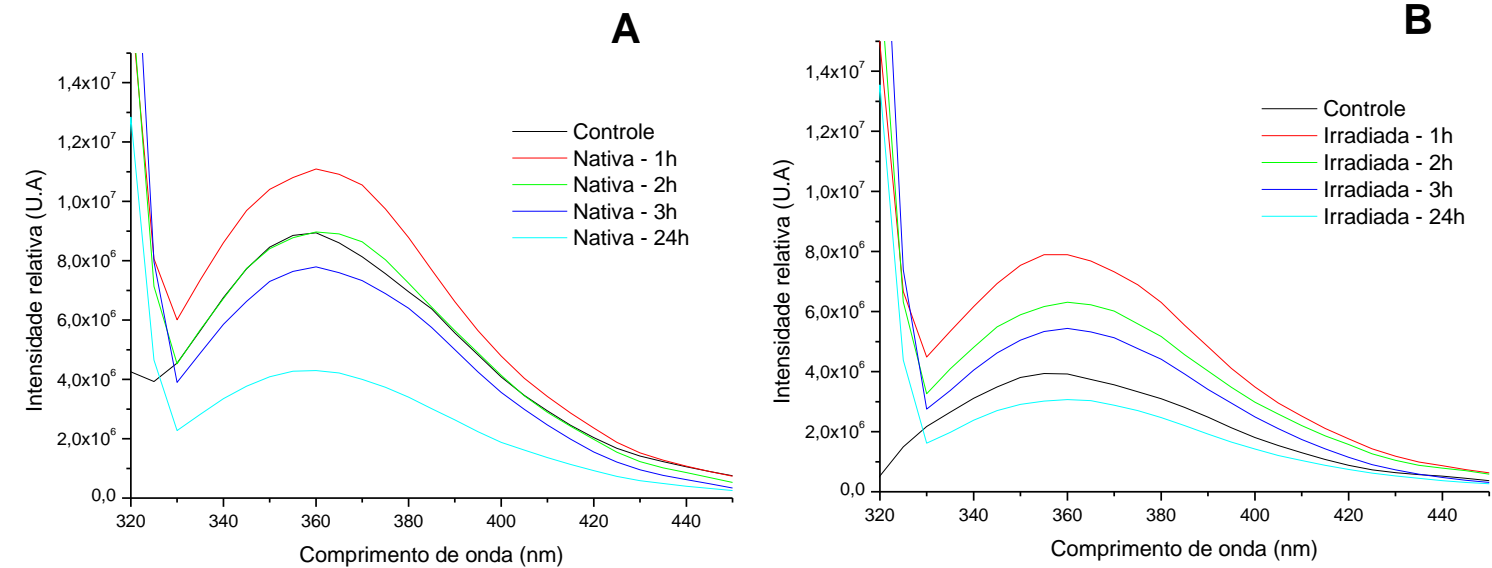

Figura 35: Espectro de fluorescência do triptofano presente na crotamina nativa $(\mathbf{A})$ e irradiada (B) em 3,0 M de guanidina.

A Figura 36 ilustra a análise de fluorescência do triptofano da crotamina em 4,0 M de guanidina. A tendência observada nos perfis anteriores se mantém tanto para a amostra nativa como para a irradiada.

A

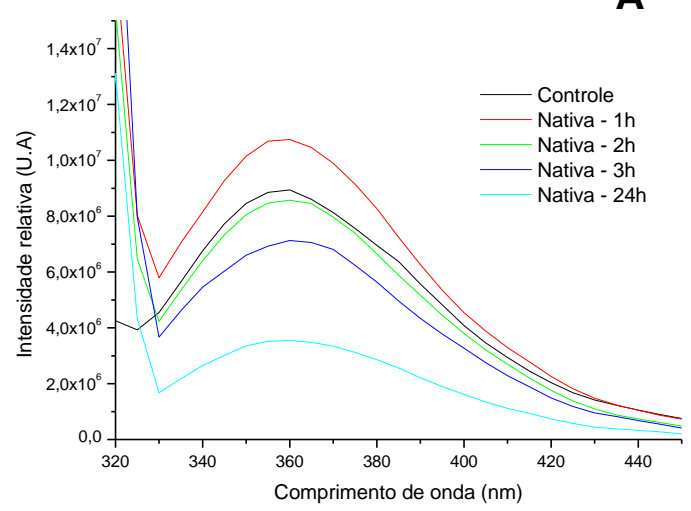

B

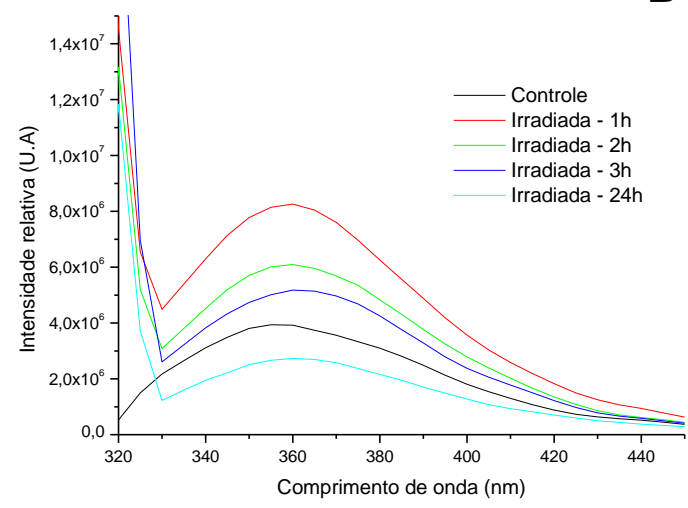

Figura 36: Espectro de fluorescência do triptofano presente na crotamina nativa $(\mathbf{A})$ e irradiada (B) em 4,0 M de guanidina.

A Figura 37 mostra a análise de fluorescência do triptofano da crotamina em 5,0 M de guanidina. É possível verificar que os resultados são bem semelhantes aos observados na figura anterior. Tal fato pode indicar que após 3,0 M de guanidina (Figura 35), a desnaturação protéica segue um padrão, não sendo relevante qual a concentração do agente desnaturante utilizado. 

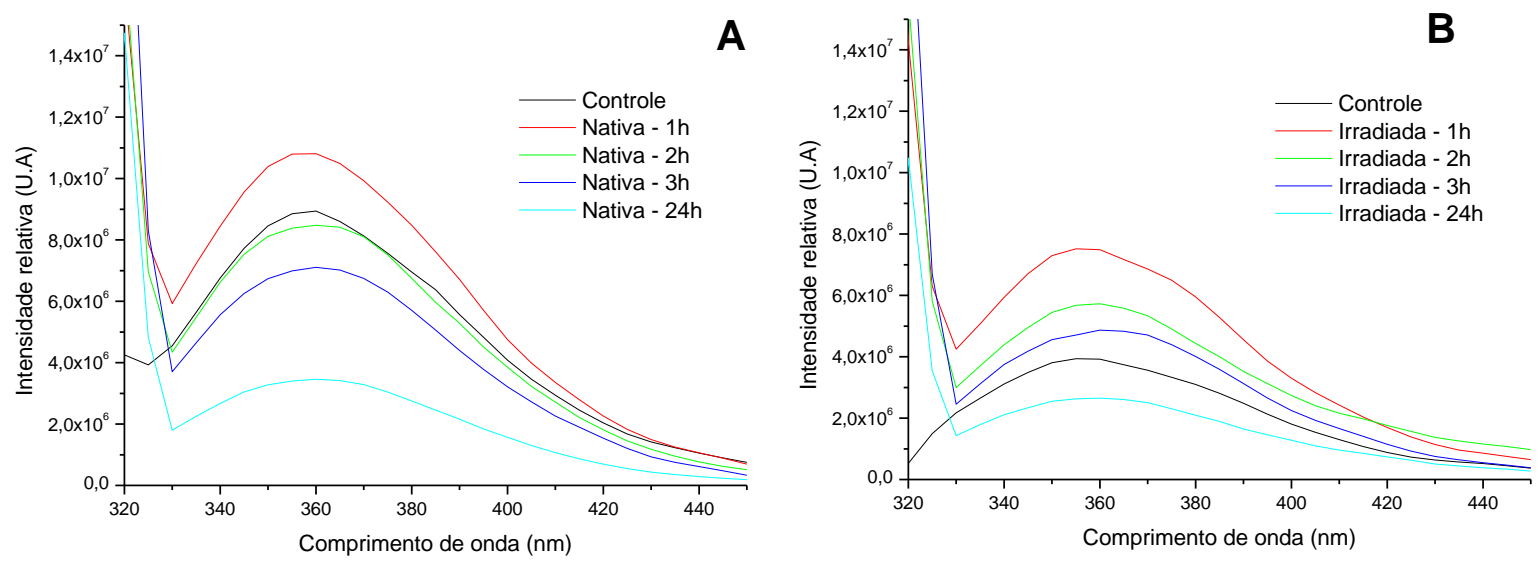

Figura 37: Espectro de fluorescência do triptofano presente na crotamina nativa $(\mathbf{A})$ e irradiada (B) em 5,0 M de guanidina.

A Figura 38 aborda a análise de fluorescência do triptofano da crotamina em 6,0 M de guanidina, última concentração testada. Mais uma vez foi possível observar o mesmo padrão dos perfis de fluorescência da amostra nativa e irradiada já mencionado anteriormente. Tais resultados sugerem, como colocado acima, que na concentração de $3,0 \mathrm{M}$, a guanidina já é capaz de promover profundas modificações estruturais na toxina. Assim, concentrações maiores do agente desnaturante não mostram mudanças significativas, pois tais alterações ocorrem de forma total, na concentração de 3,0 M.
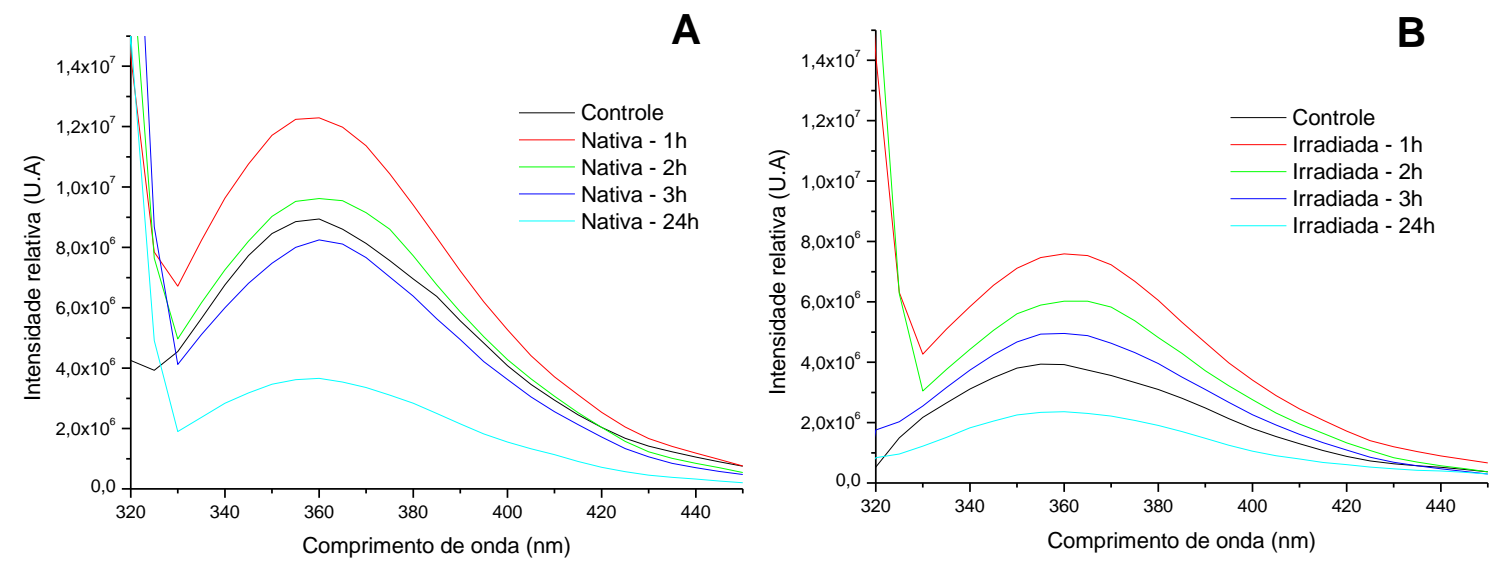

Figura 38: Espectro de fluorescência do triptofano presente na crotamina nativa $(\mathbf{A})$ e irradiada (B) em 6,0 M de guanidina. 
Outra análise realizada com os dados obtidos no teste da guanidina compara a ação desnaturante da guanidina nas amostras nativa e irradiada de acordo com a molaridade utilizada em cada periodo da leitura da fluorescência.

A Figura 39 apresenta o espectro de fluorescência na primeira hora para a amostra nativa $(\mathbf{A})$ e irradiada (B) nas diferentes concentrações de guanidina. Pode-se observar que nesta primeira hora de análise, as concentrações de 3,0, 4,0, 5,0 e 6,0 M de guanidina apresentaram um perfil semelhante. Para a amostra irradiada a variação na intensidade de fluorescência não foi tão relevante quanto àquela observada para a crotamina nativa. Porém, aparentemente, para ambas as amostras, a desnaturação protéica aumenta a intensidade de fluorescência.

A

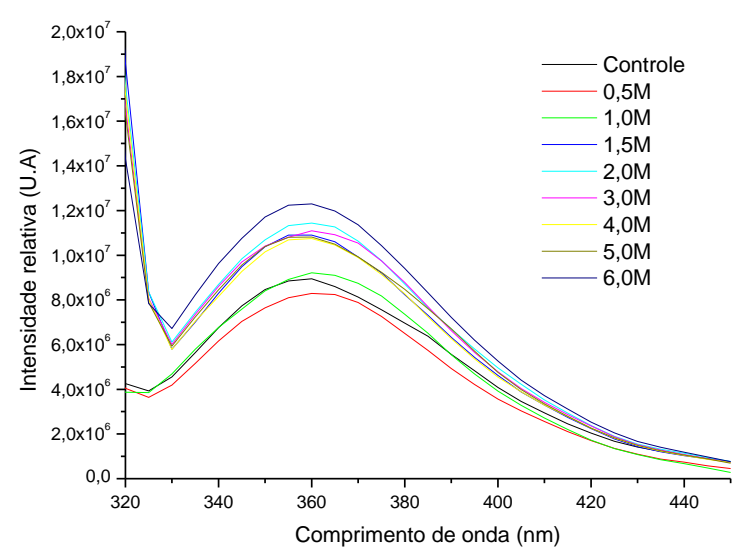

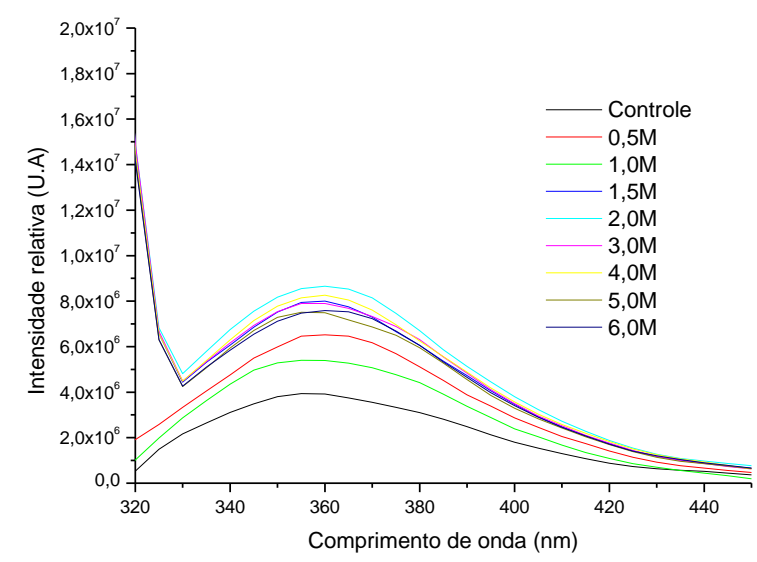

Figura 39: Espectro de fluorescência do triptofano presente na crotamina nativa $(\mathbf{A})$ e irradiada (B) na primeira hora de análise em diferentes concentrações de guanidina.

A Figura 40 ilustra o perfil de fluorescência na segunda hora para a amostra nativa $(\mathbf{A})$ e irradiada $(\mathbf{B})$ nas diferentes molaridades de guanidina. $O$ perfil de fluorescência obtido nessa segunda hora de análise apresentou intensidades de fluorescência bem próximas em todas as molaridades de guanidina, tanto para a crotamina nativa quanto para a irradiada. 

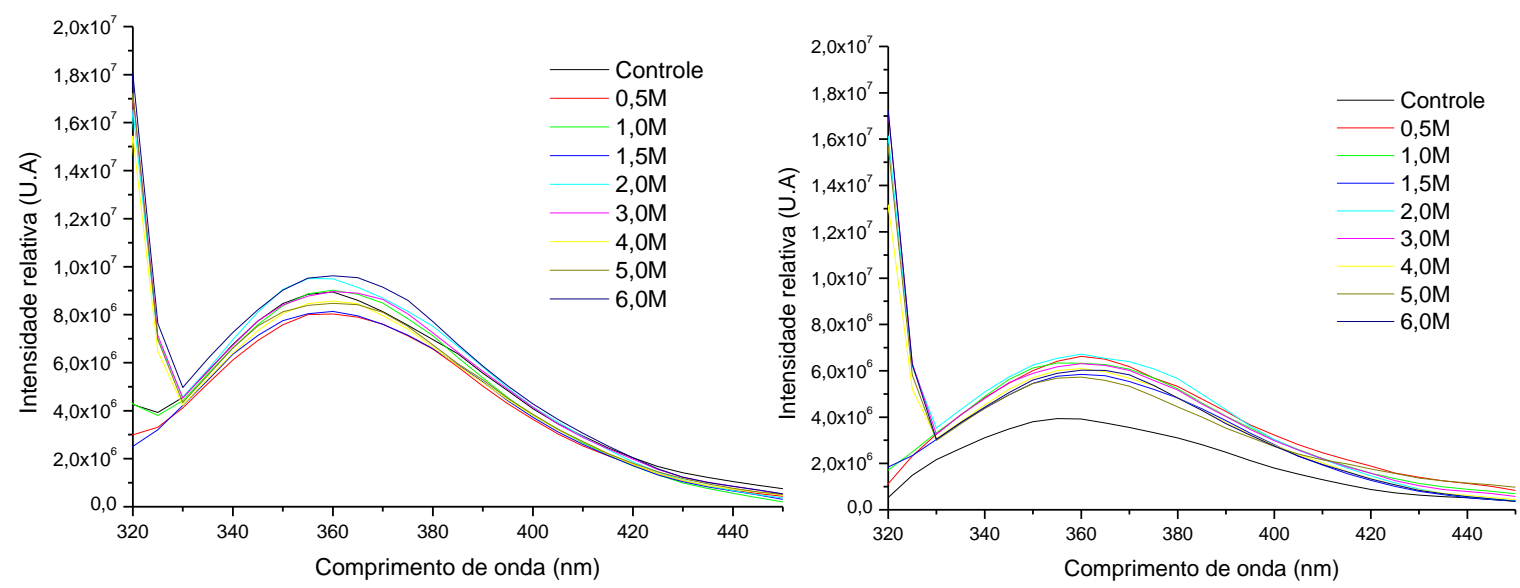

Figura 40: Espectro de fluorescência do triptofano presente na crotamina nativa $(\mathbf{A})$ e irradiada (B) na segunda hora de análise em diferentes concentrações de guanidina.

A Figura 41 mostra o perfil de fluorescência na terceira hora para a amostra nativa $(\mathbf{A})$ e irradiada $(\mathbf{B})$ nas diferentes concentrações de guanidina. Novamente não houve mudança quanto ao perfil da amostra nativa. A irradiada, porém, apresentou uma pequena variação para as molaridades de 1,0 e 2,0 M de guanididna.

A

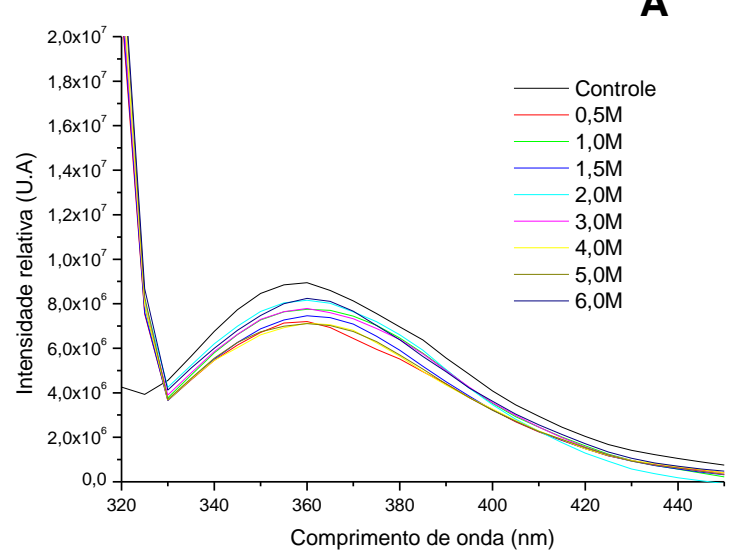

B

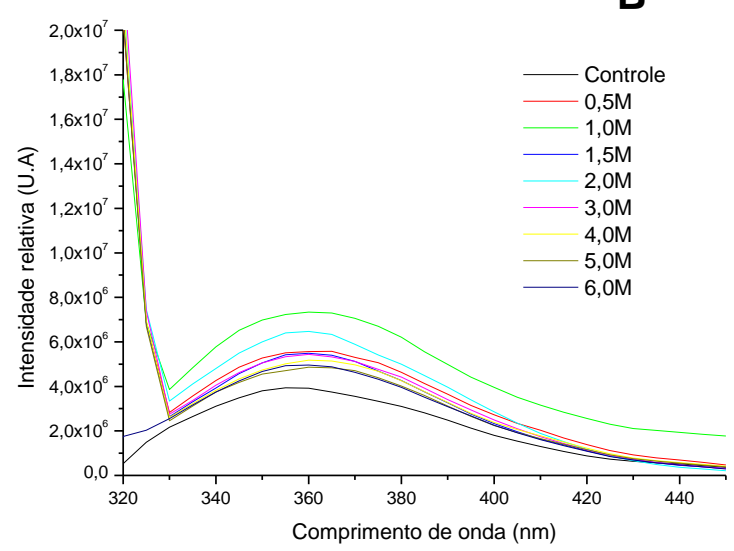

Figura 41: Espectro de fluorescência do triptofano presente na crotamina nativa $(\mathbf{A})$ e irradiada (B) na terceira hora de análise em diferentes concentrações de guanidina.

A Figura 42 apresenta o espectro de fluorescência após 24 horas para a amostra nativa (A) e irradiada (B) nas diferentes molaridades de guanidina. Nesta última análise também não se observou mudança significativa em relação às anteriores, o que sugere que o efeito total do agente caotrópico ocorra desde a primeira hora analisada. Porém a intensidade de fluorescência para a amostra nativa foi visivelmente menor do que o controle, já, para a 
amostra irradiada, a desnaturação por meio da guanidina apresentou um perfil muito semelhante ao observado para o controle, que no caso, já havia sofrido desnaturação parcial devido à radiação.
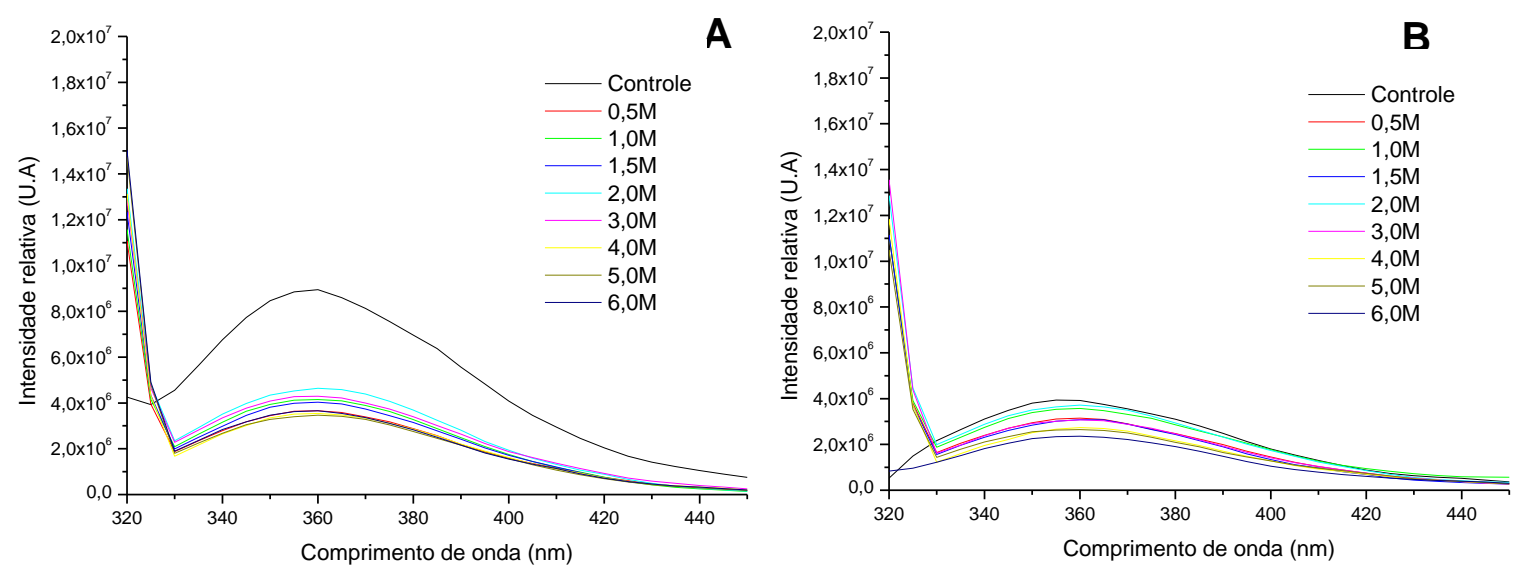

Figura 42: Espectro de fluorescência do triptofano presente na crotamina nativa $(\mathbf{A})$ e irradiada (B), após 24 horas, em diferentes concentrações de guanidina.

\subsection{Ensaios Biológicos}

A análise do efeito biológico da crotamina foi realizada por meio de contração frente a estímulos elétricos de baixa frequência $(0,05 \mathrm{~Hz})$ na presença e na ausência da crotamina nativa e irradiada, nas concentrações de 0,1 e $0,5 \mu \mathrm{g} / \mathrm{mL}$.

A Figura 43 ilustra a imagem do registro de contração obtida diretamente do programa Chart v4.2 para as amostras de crotamina nativa (B) irradiada (C), aplicadas em doses únicas, frente ao controle (A). É possível observar por meio da imagem que após a aplicação da crotamina nativa (passados 20 minutos do início do estímulo elétrico), o registro da contração apresentou considerável queda, tanto na altura dos twiches (altura do registro miográfico), quanto em termos da linha de base do registro. Mantendo as mesmas condições de análise, verificou-se que tais alterações não foram tão evidentes para a amostra irradiada. O controle, por sua vez, não apresentou alterações ao longo do experimento. 
Estes resultados preliminares, embora ainda não sejam conclusivos, trazem informações inéditas quanto à ação da crotamina irradiada sobre a contração da musculatura lisa de ratos.
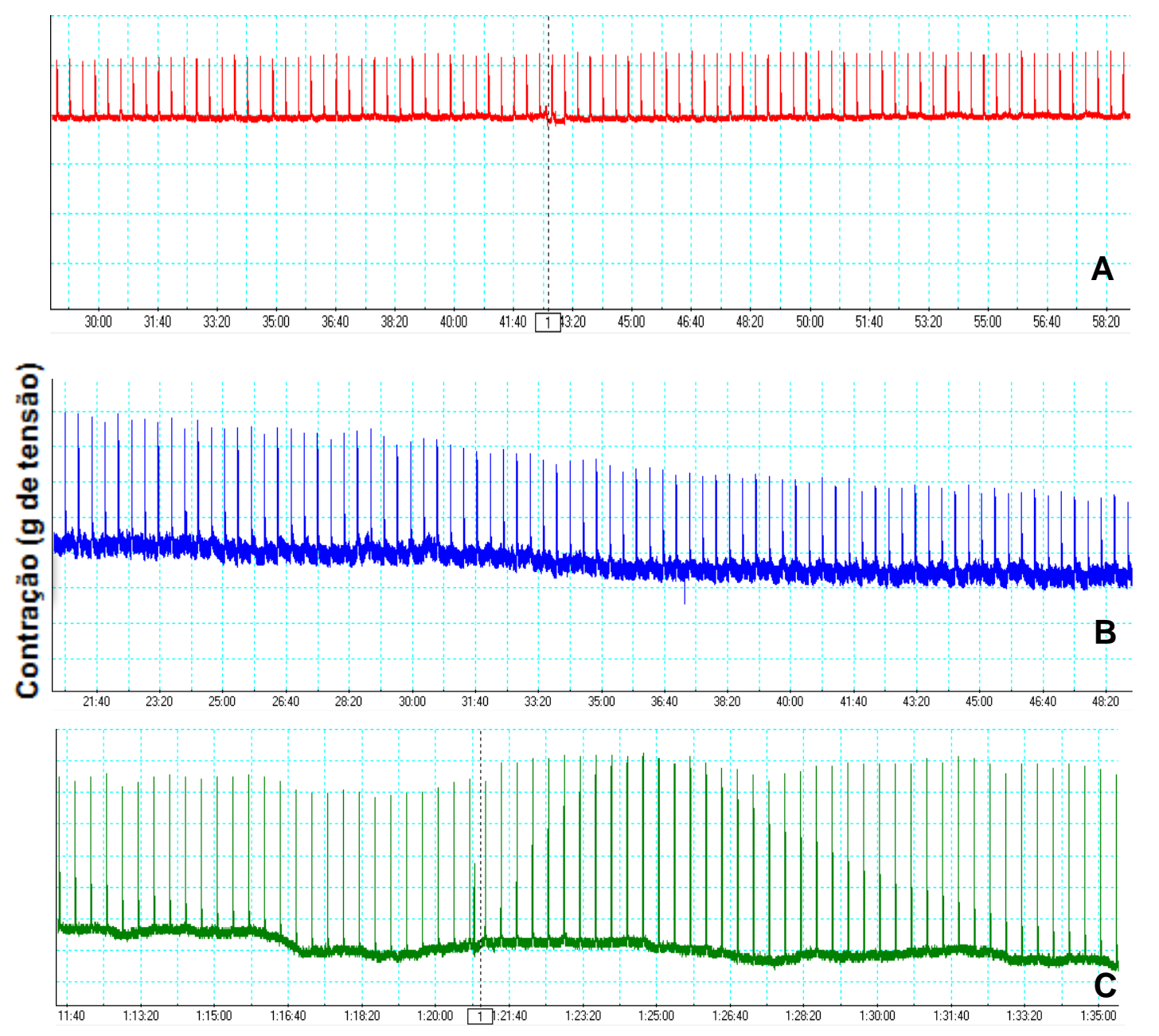

Tempo (min)

Figura 43: Registro da dose única de crotamina aplicada em DDR submetido à frequência de $0,05 \mathrm{~Hz}$. Controle $(\mathbf{A})$; crotamina nativa $(\mathbf{B})$; crotamina irradiada $(\mathbf{C})$.

A Figura 44 mostra o efeito da crotamina nativa e irradiada nas diferentes doses testadas em ductos deferente de ratos (DDR). Pode-se observar certa tendência da contração do DDR diminuir com o tempo, para as concentrações testadas $(0,1$ e $0,5 \mu \mathrm{g} / \mathrm{mL})$. Assim, a crotamina nativa nas doses de 0,1 e $0,5 \mu \mathrm{g} / \mathrm{mL}$, bem como a crotamina irradiada na dose de $0,5 \mu \mathrm{g} / \mathrm{mL}$ representaram diferença estatística em relação à diminuição da contração frente ao controle. Apenas para a crotamina irradiada em $0,1 \mu \mathrm{g} / \mathrm{mL}$ a diminuição da contração em relação ao controle não foi estatística. 


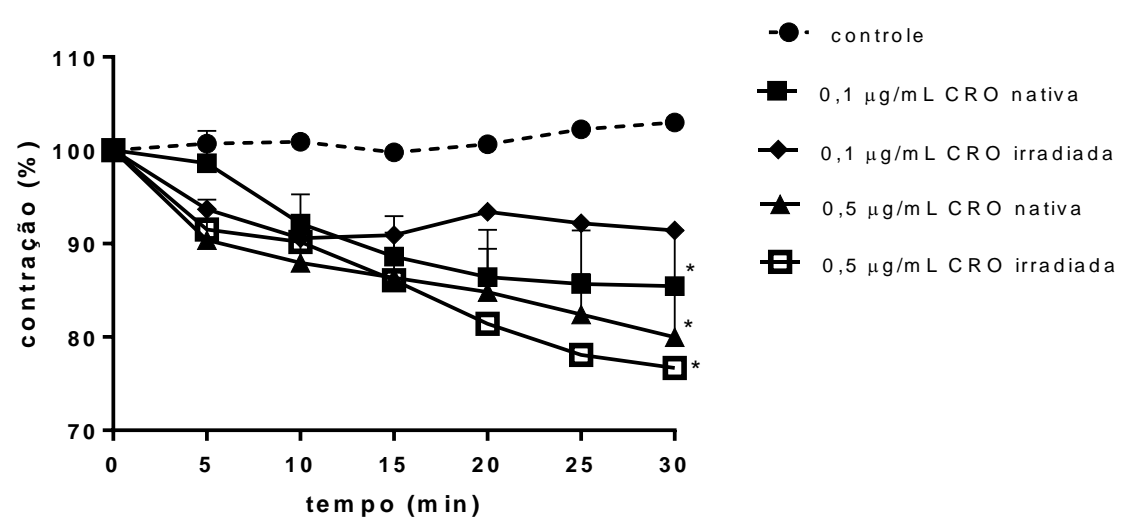

Figura 44: Representação da contração em DDR por tempo, sob estímulo a baixa frequência $(0,05 \mathrm{~Hz})$ na ausência (controle) e na presença de crotamina nativa e irradiada nas concentrações de $0,1 \mu \mathrm{g} / \mathrm{mL}$ e $0,5 \mu \mathrm{g} / \mathrm{mL}$. * Estatisticamente diferentes do grupo veículo, valor de $p \leq 0,05$.

O DDR foi também submetido à curva de frequência $(1,5,10$ e 20 $\mathrm{Hz}$ ) nas diferentes doses de crotamina (nativa e irradiada) analisadas nos ensaios de contração muscular. Sabe-se que em altas frequências a contração do DDR apresenta dois componentes: o fásico, representado por contração mais rápida do músculo; e o tônico, representado pela contração lenta.

Os dados sobre a contração fásica estão apresentados na Figura 45 que ilustra a mudança da contração muscular versus às frequências testadas. Foi possível observar que as doses de $0,1 \mu \mathrm{g} / \mathrm{mL}$, tanto da crotamina nativa quanto da irradiada, assim como a dose de $0,5 \mu \mathrm{g} / \mathrm{mL}$ da amostra nativa, apresentaram tendência à queda da contração em relação ao controle, especialmente em frequências mais altas (10 e $20 \mathrm{~Hz}$ ). A dose de $0,5 \mu \mathrm{g} / \mathrm{mL}$ da crotamina irradiada não apresentou o mesmo comportamento, visto que nas frequências de 10 e $20 \mathrm{~Hz}$ os dados obtidos foram muito próximos ao controle. 


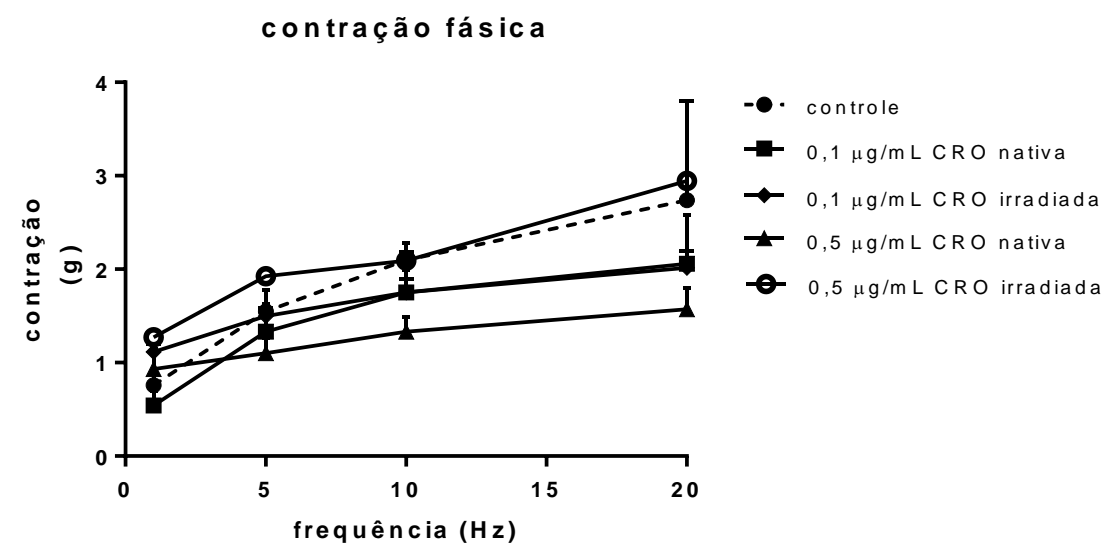

Figura 45: Curva de contração muscular (componente fásico) versus frequência (1, 5, 10 e 20 $\mathrm{Hz}$ ) em diferentes doses de crotamina nativa e irradiada.

A Figura 46 mostra o gráfico obtido na análise do componente tônico da contração muscular versus as frequências de 1, 5, 10 e $20 \mathrm{~Hz}$, para as amostras nativa e irradiada. A crotamina nativa, em ambas as concentrações, apresentou tendência a diminuir a contração tônica em relação ao controle. Já a crotamina irradiada mostrou comportamento distinto do observado para a amostra nativa, visto que houve uma tendência no aumento da contração, fato que foi mais expressivo na dose de $0,5 \mu \mathrm{g} / \mathrm{mL}$.

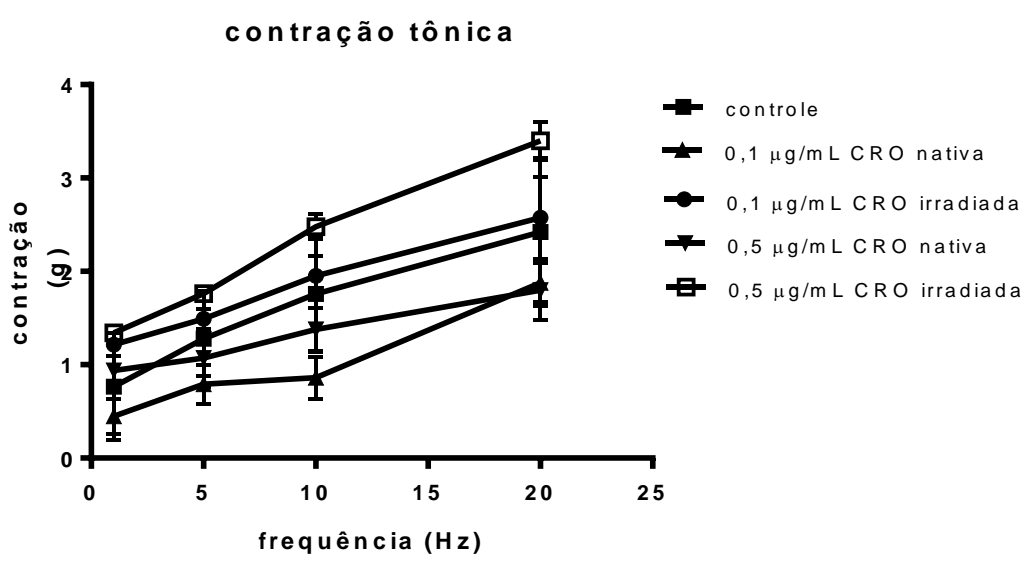

Figura 46: Curva de contração muscular (componente tônico) versus frequência (1, 5, 10 e 20 $\mathrm{Hz}$ ) em diferentes doses de crotamina nativa e irradiada. 


\section{DISCUSSÃo}

Doenças Tropicais Negligenciadas foram assim denominadas pela Organização Mundial da Saúde por persistirem, exclusivamente, nas comunidades mais pobres e marginalizadas e por terem sido erradicadas em outros lugares do mundo. Afetam, em geral, populações que costumam viver em áreas remotas e rurais, favelas urbanas ou em zonas de conflito. Como a maioria dos afetados tem pouca voz política, as doenças tropicais negligenciadas têm baixo impacto nas prioridades da agenda da saúde pública. Embora clinicamente distintas, compartilham a característica comum de persistirem em condições de pobreza, nas quais muitas vezes se associam e se sobrepõem às demais características. Mais de um bilhão de pessoas - um sexto da população mundial - sofrem de uma ou mais doenças tropicais negligenciadas.

Acidentes com serpentes são um problema de saúde pública afetando, especialmente, áreas rurais de países da África, Ásia, Oceania e América Latina. Estima-se que ocorram cerca de 2,5 milhões de envenenamentos por serpentes a cada ano no mundo, resultando em 250 mil pacientes com sequelas e pelo menos 100 mil mortes. Tal problema tem sido subestimado e, somente em abril de 2009, foi incluído na lista de Doenças Tropicais Negligenciadas da Organização Mundial da Saúde (OMS), da qual fazem parte outras 14 enfermidades (Tambourgi, 2010).

Calmette (1907) já definia a soroterapia como o melhor método no tratamento de acidentes ofídicos, e também destacava a relação direta entre a especificidade do antissoro para o gênero da serpente e a eficiência do tratamento.

No Brasil, os equinos são empregados na produção de soro contra o veneno de nossas serpentes desde 1901 (Vital Brazil). Embora estes animais apresentem grande porte, sofrem durante o processo de imunização, pois devido à baixa imunogenicidade, grandes quantidades de veneno são inoculadas a fim de obter-se uma produção eficiente de anticorpos, o que afeta diretamente sua longevidade e condições de bem estar (Rosenfeld, 1971).

Em 1894 Phisalix \& Bertrand (1894) realizaram os primeiros estudos com o objetivo de diminuir a toxicidade dos venenos utilizados na imunização 
de equinos para aperfeiçoar a produção de soro, além de melhorar a qualidade de vida dos animais soroprodutores. Desde então, diversos processos têm sido utilizados com o propósito de diminuir a letalidade das toxinas, como por exemplo: iodação (Heneine e col., 1992; Daniel e cols., 1987; Bicalho e cols., 1990), fotooxidação (Shortt \& Mallick, 1935), irradiação com raios-X (Flowers, 1963), ultravioleta (Tejasen \& Ottolenghi, 1970) e mutagênese sítio dirigida (Li e cols., 1994).

A radiação ionizante, a exemplo das metodologias citadas anteriormente, vem se mostrando como uma ferramenta promissora na destoxicação de venenos de serpentes. Esta técnica apresenta um diferencial em relação às demais, visto que além de conseguir diminuir a toxicidade do veneno, mantém, ou por vezes até melhora, as propriedades imunológicas da toxina irradiada, sem que seja adicionada outra substância à mesma (Puranananda, 1972; Kankonkar e cols., 1975; Hati e cols., 1989; Mandal e cols., 1991, 1993).

Embora diversos trabalhos tenham contribuído para o melhor entendimento da ação da radiação ionizante sobre as proteínas dos venenos de serpentes brasileiras (Murata, 1988; Nascimento, 1991, 1995; Guarnieri, 1992; Cardi e cols., 1992; Clissa, 1997; Spencer, 1995, 2000; Casare, 2003, 2008; Baptista, 2004, 2009), ainda persistem certos questionamentos quanto às mudanças estruturais ocasionadas por esse processo físico e as consequentes alterações biológicas observadas. Além disso, ainda hoje o modo de ação de diversas toxinas de venenos de serpentes não está totalmente esclarecido. Entender a maneira como tal mecanismo ocorre poderia abrir o espectro de aplicações das toxinas na área farmacológica, especialmente no caso destas terem sido expostas à radiação ionizante.

A gravidade dos acidentes envolvendo cascavéis aliada ao fato do veneno destas serpentes apresentarem poucos componentes, com alguns deles bem caracterizados do ponto de vista biológico e imunológico, nas formas nativa e irradiada, serviram de pilares para o desenvolvimento do presente trabalho que tem como foco principal as análises estruturais e consequentes alterações em funções biológicas, da crotamina (na forma nativa e irradiada), uma das mais importantes toxinas do veneno de C.d.terrificus. 
De acordo com Peltron \& McLean (2000), determinar a conformação estrutural de uma proteína pode promover um sólido entendimento da função biológica da mesma. Assim, os resultados obtidos serão discutidos sempre com o intuito de correlacionar as mudanças ocasionadas na estrutura protéica da crotamina em decorrência do processo de irradiação, com consequentes alterações na forma de ação da mesma.

Para dar início ao estudo, o veneno total da C.d.terrificus foi submetido às técnicas cromatográficas com o objetivo de isolar a proteína de interesse: crotamina. A primeira etapa realizada no fracionamento do veneno bruto foi a cromatografia de exclusão molecular (Figura 12), baseada no volume hidrodinâmico dos componentes da amostra. Nesta etapa foi possível observar a separação de 7 frações: convulxina (pico 1), delta-toxina (pico 2), giroxina (pico 3), crotoxina (pico 4), crotamina (pico 5), fração analgésica (pico 6) e tripeptídeos (pico 7). Atualmente, colunas que fornecem cromatogramas com maior resolução, permitem a verificação de um número maior de componentes, a exemplo dos picos 6 e 7 observados na Figura 12.

Foi possível analisar ainda que os picos 4 e 5 , referentes à crotoxina e crotamina, respectivamente, foram os mais representativos de todo o perfil cromatográfico. Estes dados estão de acordo com os achados de Slotta \& Fraenkel-Conrat (1938), Gonçalves \& Arantes (1956) e outros trabalhos mais recentes (Boni-Mitake, 2000; Casare, 2009). Um perfil de eluição similar ao obtido na Figura 12, cromatografia de exclusão molecular, é verificado em todos os casos de veneno crotálico, exceto para venenos de cascavéis crotamina-negativo, que não apresentam o pico 5 (Boni-Mitake, 2000).

$O$ fracionamento observado neste primeiro cromatograma deixa evidente que a crotamina ainda não está totalmente isolada. Assim, de acordo com o perfil obtido, aparecem picos após o pico de eluição da crotamina e, para garantir maior confiabilidade nos resultados, é importante que a amostra esteja o mínimo possível de contaminantes.

Dessa forma, a segunda etapa cromatográfica, em coluna de troca iônica, foi realizada para a obtenção da toxina com alto grau de pureza. Nesse caso utilizou-se uma coluna de troca catiônica (Figura 13). Para esta etapa cromatográfica, a proteína deve adquirir uma configuração eletrônica positiva, estando, portanto, em um tampão com pH menor do que o pl da proteína. Com 
base na Figura 13 foi possível verificar que o pico da crotamina mostrou-se assimétrico, ou seja, ocorreu a formação de um "ombro", especialmente na parte descendente do pico. Estes dados reforçam a idéia da existência de isoformas da crotamina, uma vez que se partiu do pool do veneno total da C.d.terrificus no qual, possivelmente, coexistem isoformas da toxina. Isoformas protéicas podem ser resultado da mudança de um único aminoácido na sequência primária da proteína. Toyama e cols. (2000) isolaram, por meio de um único passo de RP-HPLC, isoformas denominadas F2 e F3, cujas estruturas terciárias mostraram-se idênticas, diferindo em um ou dois aminoácidos apenas. Ambas as isoformas produziram paralisia espástica em camundongos e apresentaram a mesma DL50 (0,5 mg/kg de camundongo). Oliveira (2010) também observou a presença de dois picos na cromatografia de fase reversa realizada em amostra de crotamina purificada a partir do veneno total da C.d.terrificus.

Embora em condições amostrais diferentes daquelas utilizadas por Toyama e cols. (2000), tais picos sugeriram a presença de isoformas na amostra de crotamina isolada. Ponce-Soto e cols. (2007) caracterizaram duas isoformas IV-2 e IV-3 do veneno da C.d.cumanensis, e verificaram grande identidade entre essas isoformas e a crotamina da espécie C.d.terrificus em termos da sequência de aminoácidos.

Após cada etapa de fracionamento do veneno crotálico foram realizadas cromatografias analíticas em coluna de gel filtração para verificar a eficiência dos processos de isolamento. Num primeiro momento analisou-se a amostra de crotamina proveniente da exclusão molecular (Figura 14).

As mesmas condições cromatográficas utilizadas na primeira etapa de fracionamento (Figura 12) foram mantidas para o estudo analítico da toxina. Na Figura 14 observou-se, por meio da integral do perfil cromatográfico obtido, que o pico correspondente à toxina de interesse representou cerca de $89 \%$ da área total do cromatograma. Dois outros picos foram observados nesse caso, e ambos apareceram depois do pico referente à crotamina (eluídos em maior volume), o que sugere componentes de menor volume hidrodinâmico, ou seja, peptídeos presentes no veneno da C.d.terrificus. Mais recentemente, alguns trabalhos têm demonstrado a relevância de peptídeos bioativos (BPP) presentes nos venenos de serpentes. Silva e cols. (2007) sugeriram um novo 
mecanismo de ação para a atividade anti-hipertensiva do BPP 10c, um decapeptídeo bioativo do veneno da Bothrops jararaca. O estudo de BPPs têm revelado novas perspectivas na aplicação farmacológica de frações presentes no veneno total que, aparentemente, não despertaram interesse no estudo de venenos. Cabe relembrar que as melhorias em termos de resoluação de técnicas cromatográficas permitiu a identificação de frações não observadas anteriormente.

A análise em gel filtração analítica citada acima também foi reproduzida com a crotamina após a segunda etapa cromatográfica (troca iônica) e posteriormente ao processo de diálise (Figura 15). Nesse caso, o pico predominante, correspondente à crotamina, representou cerca de $98 \%$ da área total do perfil cromatográfico. Estes resultados mostraram que as duas etapas de fracionamento do veneno crotálico utilizadas para o isolamento da crotamina foram extremamente satisfatórias considerando o propósito do trabalho.

Após o processo de irradiação a toxina foi submetida à gel filtração analítica com o intuito de verificar uma possível mudança no cromatograma. Considerando o perfil obtido (Figura 16), observou-se a formação de componentes de maior volume hidrodinâmico, uma vez que foram identificados picos disformes em volume de eluição menor do que aquele observado para a crotamina (volume de 15,19 mL). Foi possível notar também que o pico da crotamina apresentou certa deformidade se comparado com o pico obtido na Figura 15, ou seja, antes do processo de irradiação, além de menor absorvância em $280 \mathrm{~nm}$. Tal situação pode sugerir alterações conformacionais da toxina assim identificadas pela formação de possíveis agregados. Porém, tal formação parece ser solúvel em tampão formiato, visto que antes da aplicação em coluna cromatográfica a amostra foi adequadamente centrifugada para a retirada de qualquer componente que não estivesse totalmente dissolvido na solução tampão. Uma vez que o valor da leitura espectrofotométrica em 280 nm está relacionado com a quantia de proteína presente na amostra, a diminuição de tal leitura no cromatograma também indicou uma possível queda na quantidade da proteína, com o mesmo volume hidrodinâmico observado para a amostra nativa, após o processo de irradiação.

A eletroforese em gel de poliacrilamida a 15\%, realizada em tampão tricina, forneceu informações sobre a pureza da crotamina, além de indicar 
mudanças na área da banda correspondente à toxina irradiada. Assim, foi possível inferir, por meio da Figura 18, que a crotamina sofreu alterações estruturais as quais modificaram a massa molecular da mesma, resultando em uma banda mais larga no gel de poliacrilamida em comparação com a crotamina nativa. Tal fato indicou, portanto, a formação de compostos de maior massa molecular na amostra de crotamina irradiada. Resultados semelhantes foram verificados na cromatografia analítica da crotamina irradiada (Figura 16), em que compostos de maior volume hidrodinâmico surgiram no cromatograma da amostra após a irradiação. Boni-Mitake (2000) também observou bandas largas ao aplicar a crotamina em gel SDS-PAGE-tricina, devido à presença de uma prolina central que forma um eixo de rotação ao ligar dois aminoácidos adjacentes na molécula de crotamina. Porém, não observou mudanças entre as bandas da crotamina nativa e irradiada. Moon \& Song (2001) verificaram que as proteínas podem ser convertidas em agregados de alta massa molecular devido à reações de cross-linking interproteínas, interações hodrofóbicas e eletrostáticas e formação de pontes dissulfeto. Baptista (2009) ilustrou alterações no perfil eletroforético da bothropstoxina-1 após irradiação sugerindo quebras nas cadeias peptídicas em consequência da ruptura de pontes covalentes.

Outra análise realizada com o objetivo de averiguar o correto isolamento da crotamina, bem como as diferenças ocasionadas pela irradiação, foi a espectrometria de massa (Figuras 19 e 20). Devido a grande sensibilidade da técnica, foi possível verificar a existência de outras moléculas na fração de crotamina purificada (Figura 19), porém em concentrações muito baixas, fato não detectado nas análises de cromatografia e gel de eletroforese. Todavia, dois picos majoritários foram identificados no perfil obtido: um dos picos confirmou $\mathrm{O}$ isolamente da crotamina indicando a massa de 4884,23 \pm 1,92 Da; o outro pico majoritário apresentou massa de 4740,73 $\pm 2,40 \mathrm{Da}$. A diferença de $143,50 \mathrm{Da}$, possivelmente corresponde a perda de dois aminoácidos no C-terminal, uma serina e uma glicina, cuja massa molecular teórica vale 144,13 Da. Outra hipótese possível é a presença de isoformas da proteína, fato já relatado anteriormente.

A crotamina irradiada apresentou um espectro mais complexo quando analisada por espectrometria de massa. Este fato sugeriu a formação 
de derivados oxidados da toxina com variado grau de modificação (Spencer, 2000). Assim, o perfil da amostra irradiada mostrou indícios de provável conversão da crotamina em um peptídeo de $5500 \mathrm{Da}$ aproximadamente. Outra possível hipótese é a formação de precipitados após o processo de irradiação, visto que tais formações não foram detectadas na espectrometria por não terem atravessado a coluna de fase reversa, o que consequentemente aumentaria a proporção do peptídeo de $5500 \mathrm{Da}$, visto que este já havia sido detectado na amostra nativa, porém em quantidade não expressiva. Portanto, novamente, verificou-se que a crotamina sofreu alterações estruturais após exposição a 2 kGy de radiação gama.

Sabe-se que a irradiação de proteínas em solução aquosa pode induzir uma série de alterações na estrutura protéica e por consequência, nas propriedades físico-químicas desta, indo desde simples ionizações, até transformações drásticas na sua estrutura primária, secundária e terciária. Tais mudanças estão relacionadas com a perda da atividade biológica além de poder interferir nas propriedades imunológicas após a irradiação (Grosch \& Hoopywood, 1979).

Assim, é de grande importância a análise da toxina de interesse sob o aspecto estrutural, além do fato da tentativa de se obter mais respostas frente às consequências no mecanismo de ação da crotamina em resposta às inúmeras mudanças conformacionais. Para tais análises foram realizadas algumas técnicas de estudo estrutural: Fluorescência, Dicroísmo Circular (CD), Microscopia de Força Atômica (AFM); análises de desnaturação protéica (temperatura e agente caotrópico) realizadas com o objetivo de identificar possíveis semelhanças entre estes processos e a o processo de irradiação da proteína; e ensaios biológicos de contração muscular para estudo do modo de ação da crotamina. Cabe ressaltar ainda o estudo inédito realizado com a toxina submetida à alta pressão hidrostática a fim de observar se tal processo poderia reverter as alterações na estrutura protéica causadas pela radiação gama. As análises sob altas pressões foram estudadas por meio de fluorescência intrínseca à toxina.

A Fluorescência é uma técnica relevante quanto à indicação de alterações estruturais em moléculas protéicas, principalmente em relação aos compostos aromáticos, como triptofano, fenilalanina e tirosina. Estes resíduos, 
quando excitados por radiação ultravioleta, em comprimento de onda específico retornam ao estado fundamental por meio da emissão de fluorescência. A fluorescência ocorre sempre a uma menor frequência (menor energia), em relação à radiação incidente, uma vez que a transição de emissão acontece após parte da energia vibracional ser descartada para a vizinhança (Atkins, 1998). Dessa maneira, observa-se que o comprimento de onda da emissão de fluorescência é sempre maior do que o utilizado na excitação do cromóforo.

A análise das proteínas por Fluorescência permitiu a abordagem da mudança estrutural frente à exposição dos resíduos de triptofano, que são os mais amplamente estudados, e estão presentes na crotamina.

O triptofano ocorre em um ou poucos resíduos na maioria das proteínas e peptídeos biologicamente ativos. A fluorescência do cromóforo é altamente sensível ao meio no qual a proteína se encontra. Assim, a intensidade relativa na emissão de fluorescência depende da natureza e da disposição de grupos funcionais da proteína, bem como das moléculas de água ao redor do triptofano (Chen \& Barkley, 1998).

$\mathrm{Na}$ avaliação dos resultados referentes à crotamina (Figura 21), toxina que apresenta apenas dois resíduos de triptofano, observou-se que a amostra irradiada apresentou intensidade de fluorescência cerca de 65\% menor em relação à intensidade da amostra nativa. $\mathrm{O}$ deslocamento do pico de emissão para a direita (maior comprimento de onda e consequentemente região de menor energia), que também é um indicativo de alterações conformacionais, não foi relevante. Sabe-se que em muitas moléculas, o resíduo de triptofano encontra-se em regiões hidrofóbicas, ou seja, regiões pouco acessíveis ao solvente. Assim, uma alteração na estrutura terciária da proteína poderia expor o resíduo de triptofano, tornando-o mais acessível ao solvente e, portanto, diminuindo o seu quenching de fluorescência, uma vez que aumentaria as perdas energéticas em interações inespecíficas do triptofano com demais compostos presentes no solvente.

Davies (1987) mostrou uma diminuição da intensidade de fluorescência quando proteínas foram expostas a produtos oxidativos provenientes da ação da radiação na molécula de água (efeito indireto). Em 2003, Sugura e cols. elucidaram diminuição significativa na emissão de 
fluorescência do triptofano presente no citocromo $c$ quando este foi submetido à radiação gama, na dose de 2 kGy. Casare e cols. (2006), ao estudarem a crotamina, sugeriram que a intensidade de fluorescência do triptofano e a ação da radiação gama mantém relação dose-dependente, sendo que quanto maior a dose de radiação, menor a intensidade de fluorescência. Assim, os dados obtidos no presente trabalho corroboram os dados na literatura.

Mais recentemente Coronado e cols. (2013) sugeriram que todas as cargas, bem como os resíduos hidrofóbicos da crotamina, estão expostos ao solvente. Tal fato poderia sugerir que mudanças conformacionais não causariam maior exposição do fluoróforo ao solvente, porém, o processo de irradiação, na dose utilizada nesse trabalho, pode levar à alterações estruturais na proteína que aumentam o gasto energético do resíduo de triptofano devido às quebras na molécula e consequentes ligações inter e intramoleculares, as quais seriam suficientes para a diminuição do quenching de fluorescência, fato observado na Figura 21.

Como já mencionado, a emissão de fluorescência intrínseca pode indicar mudanças conformacionais, especialmente na estrutura terciária da proteína, por ser um processo fortemente dependente das características da vizinhança onde o fluoróforo se encontra. Entretanto tal técnica não permite abordagens a respeito de mudanças na estrutura secundária de moléculas.

A determinação da estrutura secundária de uma proteína pode promover um importante avanço no entendimento de suas funções. Portanto, com o intuito de estudar estas possíveis alterações estruturais, a crotamina, nos estados nativo e irradiado, foi analisada por Dicroísmo Circular, um método espectroscópico bem estabelecido no estudo da estrutura secundária, da estabilidade protéica e consequentes agregações.

A estrutura secundária das proteínas é determinada pela disposição de ângulos $(\Phi, \varphi)$ que definem a orientação espacial da cadeia peptídica, e pela presença de ligações de hidrogênio específicas. Quando os ângulos da cadeia apresentam valores repetidos, o peptídeo forma uma estrutura secundária regular. De acordo com a geometria espacial de uma cadeia, são reconhecidas algumas formas estruturais denominadas: $\alpha$-hélice, folha $\beta$ e randômica (Peltron \& McLean, 2000). 
Em proteínas solúveis, o comprimento médio da hélice é de 11 resíduos, correspondendo a 3 turns (voltas, giros). Uma vez que as cadeias de grupamentos amida estão envolvidas por ligações de hidrogênio intra cadeia, a interação de hélices com outros peptídeos ou pequenas moléculas ocorre exclusivamente por meio de interações entre cadeias laterais. $\mathrm{Na} \alpha$-hélice, as pontes de hidrogênio entre os grupos $\mathrm{C}=\mathrm{O}$ e N-H são bastante estáveis porque os três átomos envolvidos são coplanares (arranjados linearmente). No caso da folha $\beta$, a orientação conformacional, tanto na forma paralela como antiparalela, ocorre de acordo com as ligações de hidrogênio na cadeia protéica, e é este fato que estabiliza esta estrutura em proteínas. Ainda em relação à estrutura secundária, pode-se observar outro tipo de conformação denominada $\beta$-turn. Tais estruturas são geralmente encontradas na superfície protéica, local onde as ligações de hidrogênio com o solvente são favorecidas. Por fim, a estrutura randômica é geralmente definida como uma conformação que não é hélice, nem folha e nem turn (Peltron \& McLean, 2000).

O fenômeno de dicroísmo circular é observado quando moléculas absorvem luz circularmente polarizada para a esquerda e para a direita em diferentes extensões. $O$ sinal em CD será observado quando um cromóforo for quiral (opticamente ativo) por uma das seguintes razões: for intrinsecamente quiral devido à sua estrutura, por exemplo, um átomo de carbono (C) com quatro diferentes ligantes; estiver ligado covalentemente a um centro quiral na molécula; ou sua localização for em meio assimétrico em virtude da estrutura tridimensional adotada pela molécula (Kelly e cols., 2005).

O cromóforo amida das ligações peptídicas em proteínas domina o espectro de CD abaixo de $250 \mathrm{~nm}$. Em proteínas constituídas por $\alpha$-hélice, uma banda negativa próxima a $222 \mathrm{~nm}$ é observada devido à forte ligação do hidrogênio neste meio conformacional. Esta transição é relativamente independente do comprimento da hélice. Uma segunda transição a $190 \mathrm{~nm}$ é dividida em uma banda negativa próximo de $208 \mathrm{~nm}$ e uma banda positiva perto de $192 \mathrm{~nm}$. Ambas as bandas são reduzidas em hélices curtas. O espectro de CD de folha $\beta$ apresenta uma banda negativa próximo a $216 \mathrm{~nm}$, uma banda positiva entre 195 e $200 \mathrm{~nm}$ e uma banda negativa perto de 175 nm. Entretanto a posição e intensidade destas bandas são variáveis, 
resultando em uma menor precisão na identificação de estrutura $\beta$ por CD em comparação à $\alpha$-hélice.

Sabe-se que quando a estrutura nativa de uma proteína, contendo regiões de $\alpha$-hélice e folha $\beta$, é desnaturada, as proporções entre tais regiões encontradas inicialmente, é alterada (Peltron \& McLean, 2000).

Na Figura 22 observou-se o perfil espectroscópico, obtido por CD, da crotamina nativa e irradiada, quando submetidas à análise por CD. Foi possível verificar alterações na estrutura secundária da proteína após irradiação, principalmente na região de transição de folha $\beta$ (195 - $200 \mathrm{~nm}$ e $216 \mathrm{~nm})$. Em 222 nm, região caracterísca da estrutura $\alpha$-hélice, observou-se que a curva da crotamina irradiada encontra-se em uma região inferior quando comparada com a toxina nativa, porém, não foi observada a banda negativa intensa característica da região de 222 nm. A região entre 208 e 210 nm apresentou maior relevância quanto às modificações observadas anteriormente para a estrutrura $\alpha$-hélice. Coronado e cols. (2013) descreveram a estrutura cristalográfica da crotamina e propuseram a conformação do tipo $\alpha_{1} \beta_{1} \alpha_{2} \beta_{2}$. Assim, aparentemente, não há predomínio da estrutura folha $\beta$, como até então se acreditava (Siqueira e cols., 2002; Nicastro e cols., 2003; Fadel, 2005). Possivelmente, após irradiação, a proteína perdeu parte da estrutura conformacional nativa, apresentando um aumento da configuração randômica, ou regiões aleatórias. Estes dados corroboram os relatos de Boni-Mitake (2001) que mostrou por meio do espectro de CD da crotamina que o fato de não aparecerem bandas características de $\alpha$-hélice não excluem a sua formação, sugerindo apenas que a crotamina nativa não possui quantidades significativas de $\alpha$-hélice, ou ainda, que tal formação estrutural foi modificada após a irradiação. Ainda segundo Boni-Mitake (2001), a negatividade acentuada observada no espectro da crotamina irradiada em comparação com o espectro obtido para a crotamina nativa, pode sugerir desnaturação protéica. Casare (2009) também observou alterações na estrutura da crotamina irradiada em comparação com a toxina nativa.

É cada vez mais aparente que informações termodinâmicas, bem como relatos estruturais, sejam requeridos para o desenvolvimento de uma consistente inter-relação entre funções estruturais, energéticas e biológicas. 
Em reconhecimento a este fato, é observado um considerável aumento em estudos voltados à caracterização termodinâmica de um grande número de moléculas biológicas (Plum \& Breslauer, 1995).

A Figura 23 ilustrou os perfis de CD obtidos a partir da mudança de temperatura, tanto para a crotamina nativa como para a irradiada. Foi possível verificar que com o aumento da temperatura as conformações estruturais observadas à $20^{\circ} \mathrm{C}$ foram desnaturadas, e em $90^{\circ} \mathrm{C}$ os perfis para a amostra nativa e irradiada foram muito semelhantes, fato que pode sugerir completa desnaturação.

Oliveira (2010) mostrou a partir da análise da crotamina, nos estados nativo e irradiado, por calorimetria diferencial que houve diferença significativa entre os perfis calorimétricos das amostras, visto que a temperatura requerida para desnaturação da proteína nativa foi de aproximadamente $46^{\circ} \mathrm{C}$, enquanto que para desnaturar a amostra irradiada tal temperatura ficou em torno de $27^{\circ} \mathrm{C}$.

Cabe ressaltar ainda que o gráfico (I) da Figura 23, que representa o perfil de $C D$ para a crotamina nativa e irradiada na temperatura de $20^{\circ} \mathrm{C}$ após o aquecimento, demonstrou que o efeito desnaturante causado pelo aumento da temperatura não foi totalmente reversível, visto que o perfil obtido neste caso foi distinto daquele observado para a temperatura de $20^{\circ} \mathrm{C}$ iniciais, porém também diferiu do perfil obtido a $90^{\circ} \mathrm{C}$, o que talvez possa ser entendido como uma "renaturação parcial" da estrutura conformacional.

A análise apresentada na Figura 24 confirmou que a temperatura, devido ao fato de causar desnaturação protéica, alterou a estrutura secundária da crotamina, tanto na amostra nativa (A) quanto na irradiada (B). Porém, visto que o processo de irradiação causa uma desnaturação parcial da proteína, foi possível observar que o perfil de CD referente à desnaturação causada pela irradiação com dose de $2 \mathrm{kGy}$ ficou semelhante aos perfis da crotamina nativa à temperatura de $40^{\circ} \mathrm{C}$ e $50^{\circ} \mathrm{C}$ aproximadamente.

Outra técnica aplicada para a investigação da crotamina irradiada, em comparação com a toxina em seu estado nativo, foi a Microscopia de Força Atômica (AFM).

O desenvolvimento da microscopia de força atômica ou Atomic Force Microscopy, por Binning, Quate e Gerber, em 1986, a partir da 
microscopia de tunelamento, possibilitou grande aumento na aplicação da microscopia de varredura de probe. O princípio fundamental da técnica de AFM é a medida das deflexões de um suporte em cuja extremidade livre está montada a sonda. Estas deflexões são causadas pelas forças que agem entre a sonda e a amostra.

O progresso na aplicação de AFM em biomoléculas é o resultado de melhorias na instrumentação, preparação de amostras e condições de aquisição de imagem (Engel \& Muller, 2000). Esta técnica, nunca foi utilizada no estudo de amostras irradiadas sendo, portanto uma ferramenta promissora no estudo de alterações estruturais em proteínas dada a sua grande sensibilidade na identificação de mudanças em nível molecular.

A Figura 25 mostrou a imagem da crotamina nativa adsorvida na superfície de mica. Foi possível identificar regiões bem definidas nessa imagem, representando uma espécie de "moléculas em cadeia". Assim, aparentemente há formações singulares para a amostra nativa, as quais apresentam um padrão preciso e bem estabelecido. As regiões destacadas em amarelo escuro representam áreas com maior altura, sugerindo provável sobreposição das formações observadas. A amostra irradiada por sua vez (Figura 27), não apresentou um padrão bem definido como foi observado para a crotamina nativa, assim, não foi possível identificar as formações de "moléculas em cadeia". Este fato pode sugerir quebras e possíveis reorganizações das moléculas, o que aconteceria de maneira aleatória, sem manter uma forma padrão. Desse modo, toda a superfície de mica ficou preenchida por possíveis agregados solúveis.

De acordo com Fisher e cols. (1999), a técnica de AFM permite estudar a correta conformação, bem como a perda estrutural de uma única molécula de proteína. Relatam ainda que mudanças na estrutura secundária podem resultar em diferentes alturas dos picos observados nas imagens, bem como irregularidades no perfil de análise de secções. Fotiadis e cols. (2002) mostraram a diversidade da técnica no estudo de amostras biológicas com perspectivas futuras no entendimento de interações moleculares em tempo real, que ocorrem dentro de sistemas biomoleculares. Katan e cols. (2014) elucidaram os resultados obtidos na dinâmica de deslocamento e remodelação de nucleossomos durante a transcrição do DNA. Assim, a microscopia de 
Força Atômica tem se mostrado como uma ferramenta importante no estudo de processos biológicos, bem como no desenvolvimento de análises estruturais, especialmente em termos de estrutura secundária das proteínas.

As Figuras 26 e 28 ilustram a imagem em 3D da análise de AFM para a crotamina nativa e irradiada, respectivamente. Essa maneira apenas evidencia a diferença observada para os dois estados da toxina.

Frente às mudanças conformacionais causadas pela radiação e a possível formação de agregados protéicos, seria interessante analisar se estas mudanças poderiam ser novamente alteradas, voltando à forma estrutural original da proteína, a partir de técnicas de renaturação protéica. Desse modo, a crotamina irradiada estaria estruturalmente mais próxima da toxina no estado nativo.

A pressão é um parâmetro físico que modula as interações proteínasolvente através da mudança de volume do sistema (Silva \& Weber, 1993; Kim e cols., 2006) e tem sido amplamente aplicada para modificar propriedades funcionais de proteínas (Qin e cols., 2012). A respeito dos efeitos observados da alta pressão hidrostática, tem sido reportado que a estrutura primária da proteína permanece intacta durante o processo, enquanto as estruturas secundária, terciária e quaternária são afetadas em diferentes graus (Chapleau e cols., 2004). Em geral, altas pressões produzem variados estagios de desnaturação protéica ou agregação dependendo principalmente de fatores como a pressão aplicada, as condições da solução na qual a proteína está dissolvida, a forma e a duração do tratamento sob alta pressão e das características da proteína em estudo (Galazka e cols., 1996).

Alguns artigos sobre a renaturação de proteínas utilizando alta pressão propõem que a renaturação das proteínas ocorre em pressões da ordem de 1 a 3 kbar (St John e cols., 1999, 200, 2002). Além disso, o mesmo grupo de autores também sugere que a descompressão lenta poderia melhorar o rendimento de renaturação das proteínas, pois a despressurização rápida poderia resultar na formação de espécies não ativas e propensas à agregação. Vallejo (2013) observou, estudando a Green Fluorescent Protein (GFP) recombinante, que a descompressão em degraus favoreceu o processo de renaturação da proteína, visto que sob tal análise a GFP apresentou maior 
intensidade de fluorescência, sugerindo conformação molecular mais próxima da estrutura nativa.

Com base nessa ideia, a fluorescência do triptofano presente na crotamina, no estado nativo e irradiado, foi analisada em pressões decrescentes, ou seja, a descompressão ocorreu em degraus, mantendo a proteína por 30 minutos em cada nível de pressão até a completa descompressão para a pressão atmosférica.

De acordo com a Figura 29 foi possível observar que o espectro de fluorescência apresentou algumas modificações em termos de intensidade relativa de acordo com a variação de pressão e tais alterações foram mais proeminentes na crotamina irradiada (B). Mudanças significativas relativas ao deslocamento do perfil fluorimétrico não foram observadas para as pressões estudadas. Assim, para a amostra nativa, em pressão atmosférica, a intensidade de fluorescência relativa, no pico de emissão do triptofano (comprimento de onda de $360 \mathrm{~nm}$ ) foi de aproximadamente 295 u.a. Na etapa seguinte a pressão foi estabilizada em $3 \mathrm{kbar}$, e, para o mesmo comprimento de onda observou-se intensidade de cerca de 245 u.a, representando uma queda de $17 \%$ na intensidade de fluorescência em relação à medida observada em pressão atmosférica. Quando a pressão foi reduzida para os valores de 2 e $1 \mathrm{kbar}$, as leituras de 263 u.a. e 292 u.a. de intensidade relativa foram obtidas, respectivamente. Tais medidas representaram diminuição de $11 \%$ para a pressão de $2 \mathrm{kbar}$ e $2 \%$ para pressão de $1 \mathrm{kbar}$. Dessa forma, a aparente alteração em termos de intensidade para as diferentes pressões testadas ocorreu da seguinte maneira: a maior pressão (3 kbar) foi a que apresentou menor intensidade de fluorescência em relação à pressão atmosférica, enquanto que, conforme a pressão foi diminuída, houve um aumento da intensidade da fluorescência (Tabela 3). O último espectro, obtido em pressão atmosférica, novamente indicou intensidade próxima ao valor observado para a primeira análise, realizada em pressão atmosférica. Portanto, parece que, nesse processo de investigação, as alterações induzidas pela alta pressão hidrostática não foram mantidas após a pressão retornar ao valor inicial.

As interações entre resíduos de aminoácidos nas estruturas terciária e quartenária de proteínas são similares (forças de van deer Waals, pontes salinas e interações hidrofóbicas). Assim, as estruturas protéicas são afetadas 
de forma similar pela ação da alta pressão (Dill, 1990; Jaenicke, 1991). A alta pressão é efetiva para desestabilizar as estruturas, promovendo a desnaturação parcial do polipeptídeo para formas menos compactas e dissociação de proteínas oligoméricas e de agregados. Deste modo, é possível que níveis de pressão que provocam a dissociação de proteínas agregadas possam também afetar as interações envolvidas na manutenção da estrutura terciária. Foi demonstrado por emissão de fosforescência de triptofano, que a aplicação de pressões relativamente baixas (1 - 2 kbar) pode induzir alterações na estrutura terciária de proteínas monoméricas (Cioni \& Strambini, 1994, 2002). De acordo com a literatura, portanto, seria possível justificar a menor intensidade de fluorescência na pressão de $3 \mathrm{kbar}$, visto que altas pressões podem promover mudanças na estrutura terciária de proteínas, com consequente desnaturação. A própria análise de fluorescência apresentada nesse trabalho (Figura 21) mostrou a diminuição na intensidade de fluorescência intrínseca da crotamina após a irradiação, que se apresenta como um processo capaz de induzir parcial desnaturação protéica, em comparação à crotamina nativa.

A Figura 29 (B), referente à crotamina irradiada, porém nas mesmas condições estudadas para a proteína no seu estado nativo, mostrou comportamento semelhante ao descrito para a crotamina nativa, porém as variações observadas nas pressões testadas foram as seguintes: intensidade de fluorescência $25 \%$ menor para pressão de 3 kbar em comparação à pressão atmosférica; $19 \%$ menor para a pressão de $2 \mathrm{kbar}$; e $6 \%$ menor para a pressão de $1 \mathrm{kbar}$. Assim, de acordo com o decréscimo da pressão, a intensidade de fluorescência apresentou um pequeno aumento, que foi mais expressivo do que aquele observado para a amostra nativa. Aparentemente, a crotamina irradiada se mostrou mais sensível às alterações estruturais sob alta pressão hidrostática do que a crotamina nativa. Tal fato pode ser explicado pelas mudanças estruturais causadas pela radiação, como quebra das pontes S-S bem como demais alterações conformacionais. Entretanto, cabe ressaltar que em todas as análises de fluorescência da amostra irradiada, os valores de intensidade ficaram abaixo daqueles observados para a crotamina nativa, sugerindo que a alta pressão hidrostática, nas condições estudadas, não foi capaz de promover a renaturação, ou seja, a intensidade de fluorescência 
medida para a toxina nativa manteve-se maior do que a obtida para a amostra irradiada.

Mais uma análise de alta pressão foi realizada com a crotamina irradiada, porém foram utilizadas pressões crescentes (Figura 30). Nesse caso, embora o comportamento tenha sido o mesmo em relação à análise com pressões decrescente, a variação na intensidade de fluorescência foi ainda menor para as pressões testadas, sendo que a pressão de 1 kbar mostrou a intensidade mais próxima da pressão atmosférica e a pressão de 3 kbar indicou a menor intensidade observada. Qin e cols. (2012) mostraram que o espectro de fluorescência obtido na análise sob alta pressão hidrostática da proteína de noz isolada, não apresentou mudanças significativas na intensidade de fluorescência entre as pressões $1.10^{-3}$ kbar (pressão atmosférica) e 3 kbar, sendo que em pressões mais elevadas, como 4 e 5 kbar, a intensidade de fluorescência foi consideravelmente maior. Vallejo (2013) verificou ao testar diferentes processos de renaturação, bem como diferentes tempos de incubação da proteína GFP em pressões intermediárias, que o tempo de incubação de 16 horas representou melhores rendimentos na renaturação protéica em comparação ao processo de descompressão gradual a cada 30 minutos. Assim, tais argumentos poderiam explicar a pequena variação observada no ensaio realizado com as amostras de crotamina irradiada.

Como já mencionado acima, a irradiação é um método que promove a desnaturação parcial das proteínas, considerando a dose total de 2 kGy utilizada nesse trabalho. Com o intuito de comparar se outro método de desnaturação teria ação semelhante à radiação ionizante, foi proposta a realização do teste com a guanidina (agente caotrópico) em diferentes concentrações.

Nas Figuras $\mathbf{3 1}$ a $\mathbf{3 8}$ foram apresentadas as análises com crotamina nativa $(\mathbf{A})$ e irradiada (B), ambas colocadas em diferentes concentrações de guanidina e diferentes tempos de incubação. O efeito do agente denaturante foi monitorado por leitura de fluorescência do triptofano. Assim, na Figura 31 observou-se a ação da guanidina na concentração de 0,5 M nas primeiras três horas de experimentação e após 24 horas do início da análise, tanto para a crotamina nativa $(\mathbf{A})$ como para a irradiada $(\mathbf{B})$. Para a crotamina nativa não houve uma modificação significativa na intensidade de fluorescência nas duas 
primeiras medidas ( 1 e $2 \mathrm{~h}$ após incubação com guanidina a 0,5 M), sendo que se observou a diminuição de cerca de $10 \%$ nos dois casos em relação ao controle (crotamina nativa na ausência de guanidina). Na terceira hora a intensidade de fluorescência diminuiu aproximadamente $20 \%$ em relação ao controle e após 24 horas de incubação, observou-se uma queda de cerca de $60 \%$. Já para a amostra irradiada foi possível observar que as leituras da intensidade de fluorescência do triptofano nas três primeiras horas foram maiores do que o controle (crotamina irradiada na ausência de guanidina). Os valores observados foram $64 \%$ maior após a primeira e segunda hora de análise e 38\% maior na terceira hora. Apenas a última leitura, 24 horas depois da incubação com 0,5 M de guanidina, que a intensidade de fluorescência diminuiu cerca de $20 \%$ em relação ao controle.

$\mathrm{Na}$ Figura 32 (guanidina na concentração de 1,0 M) verificou-se para a amostra nativa (A) que a primeira e segunda leitura de intensidade de fluoresência foram extremamente próximas ao controle. Foi possível observar uma queda de cerca de $13 \%$ para a fluorescência lida depois de $3 \mathrm{~h}$ de incubação e após $24 \mathrm{~h}$ a diminuição na intensidade de fluorescência foi aproximadamente de $53 \%$. Para a crotamina irradiada por sua vez, apenas após 24 horas obteve-se leitura de fluorescência $8 \%$ menor do que o controle. Para as leituras de fluorescência na primeira, segunda e terceira hora a intesidade de emissão de fluorescência aumentou em 37\%, 62\% e 87\%, respectivamente.

A partir da Figura 33 (guanidina na concentração de 1,5 M) foi possível observar um comportamento semelhante para a amostra nativa e para a amostra irradiada de acordo com o aumento da concentração do agente caotrópico. Assim, considerando a crotamina nativa (A), a intensidade de fluorescência foi mais intensa do que o controle apenas na primeira hora de análise, sendo que a diferença ficou em torno de 20\%. Para a análise após 2 horas a intensidade de fluorescência mostrou-se muito próxima ao controle, e para as análises de 3 e 24 horas a intensidade foi menor em relação ao controle, sendo que a diferença mais expressiva foi após 24 horas (intensidade de fluorescência cerca de $50 \%$ menor). Para a crotamina irradiada (B), a partir da concentração de 1,5 M de guanidina, a fluorescência do triptofano foi maior do que o controle para as três primeiras horas de análise, sendo que na 
primeira hora apresentou a intensidade duas vezes maior do que o controle, a leitura na segunda hora apresentou um aumento de aproximadamente $60 \% \mathrm{em}$ relação ao controle e na terceira hora esse aumento foi cerca de 30\%. Após 24 horas de análise a leitura de fluorescência apresentou diminuição em torno de $30 \%$ em comparação ao controle. Portanto, para a crotamina nativa, a guanidina, na primeira hora, causou mudanças conformacionais na proteína que resultaram em aumento da fluorescência do triptofano. Nas demais horas a intensidade mostrou-se menor do que o controle, sugerindo que o maior tempo de incubação da proteína com o agente desnaturante causou mais alterações estruturais do que a cresente concentração da guanidina. Para a amostra irradiada, aparentemente apenas após 24 horas de incubação da proteína com a guanidina que as alterações conformacionais resultaram em diminuição na intensidade de fluorescência, pois nas três primeiras horas a intensidade foi maior do que o controle.

Sabe-se que a guanidina é um agente desnaturante, portanto, um aumento na concentração deste agente ou o maior tempo de incubação com o mesmo, consequentemente, causará maior desnaturação na proteína. Aparentemente $\mathrm{o}$ contato da crotamina nativa com 0 agente desnaturante causa, inicialmente, alterações que podem diminuir a exposição do triptofano ao solvente; com o aumento do tempo de incubação porém, essas mudanças estruturais são direcionadas a maior exposição do fluoróforo, diminuindo assim a intensidade de fluorescência do mesmo. Quanto à crotamina irradiada, o efeito da guanidina no aumento da intensidade de fluorescência foi identificado em um período maior da análise, sendo que apenas após 24 horas o comportamento foi no sentido de diminuir a intensidade, sugerindo que as mudanças conformacionais causadas pela radiação parecem dificultar, ou até mascarar a ação desnaturante da guanidina. Observou-se ainda que a leitura de fluorescência após 24 horas mostrou maior desnaturação para a crotamina nativa. Tal fato pode ser explicado pela desnaturação parcial que a radiação promove na proteína, assim, a desnaturação por guanidina não revelou uma diferença tão significativa quanto aquela observada para a toxina nativa, pois as mudanças estruturais causadas pelo agente caotrópico já haviam sido parcialmente realizadas pela radiação ionizante. 
A outra análise realizada por meio dos dados obtidos com o teste da guanidina mostrou a ação deste agente nas diferentes concentrações a cada período no qual foi realizada a leitura da fluorescência (1, 2, 3 e 24 horas).

Observou-se, para a crotamina nativa na primeira hora de análise (Figura 39 A), que as concentrações de 0,5 e $1 \mathrm{M}$ de guanidina não causaram efeitos significativos na intensidade de fluorescência do triptofano, uma vez que esta permaneceu muito próxima à fluorescência da amostra controle. Nas concentrações seguintes $(1,5,2,3,4,5$ e $6 \mathrm{M})$ a fluorescência medida apresentou valores maiores do que o controle, sugerindo que a desnaturação causada pelo agente caotrópico parece diminuir as interações do fluoróforo com o solvente, o que causaria um aumento na sua intensidade de fluorescência. Para a amostra irradiada nessa primeira hora (Figura 39 B) em todas as concentrações de guanidina observou-se maior intensidade relativa de fluorescência em comparação com o controle, mostrando que, da mesma forma que observado para a crotamina nativa, a desnaturação aparentemente diminuiu a exposição do triptofano ao solvente.

Na Figura 40, após duas horas de incubação com a guanidina, o aumento na intensidade de fluorescência verificado nas Figuras 39 A e B, não foi tão relevante, sendo que para a crotamina nativa $(\mathbf{A})$ prativamente todas as intensidade ficaram bem próximas ao valor obtido para o controle, e para a crotamina irradiada (B), as intensidades de fluorescência para todas as concentrações de guanidina foram muito parecidas, porém, todas ainda maiores do que o controle.

A Figura 41, três horas de incubação com o agente desnaturante, mostrou comportamento semelhante ao observado para a amostra nativa (A) na segunda hora, com sutil tendência na diminuição da intensidade de fluorescência do triptofano. Para a crotamina irradiada (B) ainda foi possível identificar valores maiores de intensidade de fluorescência do triptofano em relação ao controle.

$\mathrm{Na}$ Figura 42, análise após 24 horas de incubação das amostras com guanidina, observou-se que a intensidade de fluorescência para a amostra nativa (A) apresentou considerável diminuição em todas as concentrações de guanidina testadas, sugerindo possível desnaturação na proteína. Para a amostra irradiada (B) por sua vez, a intensidade foi menor em comparação ao 
controle, mas não tão intensa quanto aquela observada para a crotamina nativa, possivelmente pelo fato do controle para a amostra irradiada apresentar-se com alterações estruturais que já resultaram em menor intensidade de fluorescência quando comparado com a intensidade observada para o controle da amostra nativa.

Cabe ressaltar que a irradiação de proteínas é um fenômeno probabilístico, ou seja, os dados obtidos nas análises mostradas acima representam apenas uma média do que de fato acontece com as toxinas em solução quando submetidas à radiação ionizante. Dessa forma, a interpretação das informações obtidas deve ser realizada com cautela sempre levando em consideração que diversas estruturas conformacionais coexistem em uma amostra irradiada, indo desde agregados insolúveis até estruturas intactas energeticamente.

Em termos de atividade biológica, a crotamina tem demonstrado um amplo espectro de ações como, por exemplo, a capacidade em penetrar membrana de diferentes tipos celulares; a ação como agente antitumoral contra diversos tipos de linhagens celulares tumorais, mas inativa contra células normais; despolarização irreversível da membrana e contrações repetitivas e espontâneas do músculo esquelético de mamíferos (Kerkis e cols., 2011; Chang \& Tseng, 1978; Rizzi e cols., 2007; Peigneur e cols., 2012) entre outras.

Embora muitos trabalhos tenham revelado perspectivas promissoras em relação à aplicação da crotamina na área da saúde e como ferramenta farmacológica, ainda não foi possível concluir qual o seu mecanismo de ação, ou seja, ainda restam dúvidas quanto ao envolvimento dos diferentes tipos de canais iônicos, à participação e mobilização dos estoques intracelulares de $\mathrm{Ca}^{2+}$, a liberação de neurotransmissores, sua citotoxicidade, bem como a modulação de receptores que participam da resposta neuromuscular.

De acordo com trabalhos na literatura, a crotamina é conhecida por sua ação despolarizante em membrana da musculatura esquelética. Hong \& Chang (1983) creditaram tal efeito ao aumento do influxo de $\mathrm{Na}^{+}$no músculo estriado. Mais tarde, foi descrito que a crotamina teria ação sobre esses canais de maneira indireta (Rizzi e cols., 2007; Matavel e cols., 1998). Em 2009, Yount e cols. propuseram que a crotamina poderia agir bloqueando canais de $\mathrm{K}^{+}$ voltagem-dependente, baseado na proximidade da estrutura tridimensional 
entre a crotamina e as $\beta$-defensinas humana, cuja ação bloqueadora de $\mathrm{K}^{+}$já havia sido descrita. Além disso, outra atividade descrita da crotamina é um aumento na liberação basal de acetilcolina (ACh) no sistema nervoso central de ratos (Camillo e cols., 2001), fato que poderia estar relacionado com seu efeito na contração da musculatura esquelética. Embora ainda não haja um consenso em relação ao mecanismo de ação da crotamina na musculatura esquelética, esses dados indicam a notória quantidade de experimentos já realizados considerando o modelo biológico de musculatura estriada.

Com o intuito de melhorar a compreensão quanto ao modo de ação da crotamina, bem como a elucidação do mecanismo de ação em musculatura lisa, o ducto deferente de rato (DDR) foi utilizado como modelo experimental. $O$ DDR é um dos órgãos periféricos mais densamente inervados pelo sistema nervoso autônomo simpático (Batra, 1974), fato que o torna uma importante ferramenta para estudos que envolvam a neurotranmissão e a ação de drogas adrenérgicas. Portanto, no presente trabalho, foi escolhido o estudo do mecanismo de ação da crotamina em musculatura lisa, visto que não há estudos na literatura sob tais aspectos.

Além disso, uma vez conhecido o modo de ação da toxina nativa, seria interessante saber se as alterações estruturais causadas pela radiação também modificariam o mecanismo de ação da mesma.

Nos experimentos de eletrofisiologia, a crotamina foi capaz de alterar a resposta dos twitches em doses únicas de crotamina nativa e irradiada (Figura 43). Embora ainda não seja possível expor dados plenamente conclusivos, existe uma tendência para uma diminuição da contração muscular, tanto para a amostra nativa (B), quanto para a amostra irradiada (C) em comparação ao controle $(\mathbf{A})$, porém esta queda nos twiches observada foi menos significativa para a amostra irradiada.

A Figura 44 ilustrou o efeito da crotamina nativa e irradiada, ambas nas doses de 0,1 e $0,5 \mu \mathrm{g} / \mathrm{mL}$, em DDR sob estímulos elétricos à baixa frequência $(0,05 \mathrm{~Hz})$. Em todas as doses houve diferença estatística na diminuição da contração muscular em relação ao controle, exceto para a crotamina irradiada na dose de $0,1 \mu \mathrm{g} / \mathrm{mL}$, que não apresentou diminuição 
significativa, sugerindo menor efeito na promoção da queda da contração muscular de DDR em comparação ao efeito causado pela proteína nativa.

Como já mencionado, estudos de eletrofisiologia com crotamina em musculatura esquelética já haviam demonstrado que quando a toxina era adicionada à preparação isolada do músculo diafragma de ratos e camundongos, aumentava a força contrátil, aumentando assim os twiches (Ponce-Soto e cols., 2007; Silva e cols. 2013; Chang \& Tseng 1978). Assim, os efeitos observados neste trabalho, tanto para a amostra nativa quanto para a irradiada, mostraram ação contrária da toxina em musculatura lisa, se comparados aos relatos na literatura com estudo de musculatura esquelética.

A junção neuromuscular autônoma difere em vários aspectos importantes da já conhecida junção neuromuscular esquelética. Uma das características essenciais deste modelo é que o neurotransmissor é lançado pelas viscosidades das porções terminais das fibras nervosas da musculatura lisa. Um neurotransmissor age como mensageiro químico da ativação neural. Estudos de neurotransmissão autônoma revelaram uma multiplicidade de neurotransmissores atuantes no sistema nervoso autônomo (Burnstock, 1988).

Sabe-se que o ducto deferente é um órgão cuja transmissão simpática é caracterizada pelo processo de co-transmissão, no qual dois neurotransmissores, a noradrenalina e o ATP, são liberados na fenda sináptica e atuam de modo sinergético (Burnstock, 1988). O ATP, após ser liberado para a fenda sináptica, ativa receptores purinérgicos ligados a canais iônicos de $\mathrm{Ca}^{2+}$ e promovem a entrada de $\mathrm{Ca}^{2+}$ para a célula. O ATP é rapidamente degradado e convertido em ADP, AMP e adenosina por ectonucleotidases. O receptor purinérgico mais sensível ao ATP no músculo liso do ducto deferente de ratos é o receptor ionotrópico $P_{2 x}$ que favorece a entrada de $\mathrm{Ca}^{2+}$. $\mathrm{A}$ contração causada pelo ATP é uma contração do tipo fásica, caracterizada por ser rápida, visto que é resultante da entrada de $\mathrm{Ca}^{2+}$ diretamente dos canais iônicos. As contrações fásicas são induzidas por baixas frequências e são aquelas representadas pelos twiches, já observados na Figura 43.

A Figura 45 ilustrou o perfil de contração fásica, nas diferentes frequências analisadas $(1,5,10$ e $20 \mathrm{~Hz})$, para a crotamina nativa e irradiada. Embora nenhum dado tenha sido estatisticamente diferente, há uma aparente tendência da toxina em diminuir essa contração, tanto em baixas como em 
altas frequências. Dessa forma, pode-se indagar que a toxina tenha possivelmente ação pré-sináptica, atuando na contração induzida pela liberação de ATP, mas ainda se fazem necessários muitos estudos para realmente serem alcançadas infomações mais conclusivas sobre como se dá a ação da crotamina sobre o ATP. Apenas a crotamina irradiada na dose de 0,5 $\mu \mathrm{g} / \mathrm{mL}$ parace ter apresentado contração sutilmente maior do que o controle.

O outro neurotransmissor responsável pela contração da musculatura em DDR, a noradrenalina, ativa receptores metabotrópicos $\alpha_{1}$ adrenérgicos das células musculares do vaso deferente e promove a formação de fosfolipase $\mathrm{C}$ (PLC) e de trifosfato de inositol $\left(\mathrm{IP}_{3}\right)$. $\mathrm{O} \mathrm{IP}_{3}$ se liga aos receptores de membrana do retículo sarcoplasmático e promove a liberação de $\mathrm{Ca}^{2+}$ dos estoques. Parte da noradrenalina é rapidamente recaptada e metabolizada por enzimas intracelulares como a monoamino oxidase (MAO) e catecol-O-metiltransferase (COMT). A noradrenalina é responsável pela contração lenta da musculatura lisa, chamada de contração tônica, e ocorre apenas em frequências mais elevadas (Burnstock, 1988).

A Figura 46 ilustrou o perfil de contração tônica, nas frequências de 1, 5, 10 e $20 \mathrm{~Hz}$, para a crotamina nativa e irradiada. Nessa análise foi possível observar um comportamento anômalo entre a toxina nos dois estados, sendo que a crotamina nativa, tanto na concentração de 0,1 como na de 0,5 $\mu \mathrm{g} / \mathrm{mL}$, apresentou tendência a diminuir a contração tônica em relação ao controle. A crotamina irradiada, porém, em ambas as concentrações, mostrou tendência a aumentar a contração.

Sabe-se que mudanças estruturais causadas pela radiação ionizante podem alterar a ação da toxina em modelos biológicos. Oussedik-Oumehdi \& Laraba-Djebari (2008), ao estudarem o efeito da radiação gama em veneno de serpente Cerastes cerastes observaram que a radiação ionizante parece diminuir a toxicidade do veneno devido às modificações estruturais ocorridas em proteínas constituintes do veneno, por perda da suas atividades ou por incapacidade de reconhecer células alvo. Porém algumas atividades enzimáticas parecem não sofrerem alterações quando o veneno foi submetido à radiação, ou seja, algumas atividades parecem ser resistentes à radiação 
gama, sendo necessárias doses mais altas para ter completa perda da atividade biológica das proteínas constituintes do veneno.

Assim, há indícios de que, na dose de 2 kGy, nem todas as funções das proteínas são afetadas da mesma forma. Tal fato poderia explicar o comportamento da crotamina irradiada, sendo que as mudanças conformacionais podem ter afetado o modo de ação da proteína sobre a via de liberação da noradrenalina na contração tônica, em comparação à ação da toxina nativa. Porém, a ação da crotamina irradiada na contração fásica, que não segue a mesma via de indução da contração tônica, apresentou-se semelhante àquela observada para a amostra nativa, porém, se mostrou apenas menos expressiva.

Embora os resultados obtidos neste trabalho tenham trazido mais conhecimentos sobre a crotamina irradiada, as metodologias empregadas não foram suficientes para elucidar completamente os efeitos que a radiação ionizante causa nas proteínas. Cabe assim, dar continuidade à pesquisas futuras com o objetivo de elucidar todas as mudanças decorrentes do processo de irradiação. 


\section{CONCLUSÕES}

- A toxina do veneno da C.d.terrificus, crotamina, foi efetivamente isolada por meio de técnicas cromatográficas;

- As estruturas, secundária e terciária, analisadas por Dicroísmo Circular e Fluorescência, respectivamente, foram modificadas após a irradiação com dose de 2 kGy;

- A técnica de AFM também mostrou mudanças significativas em relação à estrutura da crotamina após a irradiação;

- Os testes de desnaturação por guanidina mostraram, por meio da análise de fluorescência do triptofano, comportamento anômalo em relação à desnaturação parcial devido à irradiação da toxina, visto que o agente caotrópico por vezes aumentou a intensidade de fluorescência intrínseca à crotamina;

- Os testes de desnaturação por temperatura, analisados por meio de Dicroísmo Circular, ilustraram que as temperaturas entre 40 e $50 \stackrel{\circ}{\circ} \mathrm{C}$ apresentam perfil semelhante àquele obtido para a crotamina irradiada;

- A desnaturação por temperatura gerou alterações parcialmente reversíveis na estrutura da proteína;

- A alta pressão hidrostática causou alterações estruturais na crotamina nativa e aparentemente não promoveu a renaturação da toxina irradiada. Porém, ao retornar para pressão atmosférias as alterações geradas pela pressão não foram mantidas;

- Os ensaios farmacológicos mostraram que a crotamina irradiada foi menos eficaz na diminuição da contração muscular do ducto deferente de ratos em comparação com a crotamina nativa; 
- A crotamina irradiada apresentou comportamento distinto daquele observado para a toxina nativa no caso da contração tônica, modulada por noradrenalina. 


\section{REFERÊNCIAS BIBLIOGRÁFICAS}

ANDRIANI, E.P. Irradiação da crotoxina em solução aquosa: influência das principais espécies reativas nas alterações estruturais, biológicas e imunológicas. 1995. Dissertação (Mestrado) - Instituto de Pesquisas Energéticas e Nucleares, São Paulo.

ALEXANDER, G; GRUTHUSEN, J; ZEPEDA, H. \& SCHWRTZON, R.J. Gyroxin, a toxin from the venom of Crotalus durissus terrificus, is a thrombin-like enzyme. Toxicon. v. 26(10), p. 953-960, 1988.

ATKINS, P.W. Physical Chemistry. 6ª Edition.Oxford University Press, 1998.

BAPTISTA, J.A. Aspectos da resposta imune frente a antígenos protéicos irradiados com Co-60. 2004. Dissertação (Mestrado) - Instituto de Pesquisas Energéticas e Nucleares, São Paulo.

BAPTISTA, J.A. Resposta imune frente à Bothropstoxina-1 irradiada com ${ }^{60} \mathrm{Co:}$ identificação das principais citocinas envolvidas e a participação de substâncias scavengers. 2009. Tese (Doutorado) - Instituto de Pesquisas Energéticas e Nucleares, São Paulo.

BARUFFALDI, R. \& OLIVEIRA, M.N. de. Fundamentos de tecnologia de alimentos. São Paulo: Atheneu, 1998. 317p.

BASTOS, C.A. Otimização de Metodologia por Cromatografia Líquida em Fase Reversa por Pareamento lônico para Análise Simultânea de Paracetamol, Cloridrato de Fenilefrina e Maleato de Carbinoxamina em Formulações Farmacêuticas. 2008. Dissertação (Mestrado) - Universidade Federal de Juiz de Fora, Minas Gerais.

BATRA, S.K. Sperm transport through vas deferens: review of hypotheses and suggestions for a quantitative model. Fertil Steril. v. 25(2), p. 186-202, 1974.

BELTRAN, J.R.; MASCARENHAS, Y.P. SAXS study of the snake toxin a-crotamine. Eur. Biophys., v. 17, p. 325-329, 1990.

BICALHO, R.X.; ROCHA, O.A.; HENEINE, L.G.D.; MAGALHÃES, A.; HENEINE, I.F. The effect of stepwise iodination on biological properties of Bothrops jararaca venom. Toxicon, v. 28(2), p. 171-179, 1990.

BINNING, G.; QUATE, C.F. \& GERBER, Ch. Atomic Force Microscope. Phys. Rev. Lett. v. 56, 930p., 1986.

BOCHNER, R. \& STRUCHINER, C.J. Epidemiologia dos acidentes ofídicos nos últimos 100 anos no Brasil: uma revisão. Cad. Saúde Pública, Rio de Janeiro, v. 19(1), p. 7-16, 2003. 
BON, C. Snake venom \& pharmacopeia. 1994. In: Bauchot, R. (Ed.). Snakes: a natural history. Sterling Publishing Company, Inc., New York, p.194-203.

BONAN, P.R.F.; LIMA, J.S.; MARTELLI, D.R.B.; DILVA, M.S.; CARVALHO, S.F.G.; SILVEIRA, L.O.M.; JÚNIOR, H.M. Perfil epidemiológico dos acidentes causados por serpentes venenosas no norte do estado de Minas Gerais, Brasil. Rev Med Minas Gerais, v. 20(4), p. 503-507, 2010.

BONI-MITAKE, M. Estudos Bioquímicos e Farmacológicos das Crotaminas Nativa e Irradiada com Radiação Gama de ${ }^{60}$ Co. 2000. Tese (Doutorado) - Instituto de Pesquisas Energéticas e Nucleares, São Paulo

BONI-MITAKE, M.; COSTA, H.; SPENCER, P.J.; VASSILIEFF, V.S.; ROGERO, J.R. Effects of ${ }^{60} \mathrm{Co}$ gamma radiation on crotamine. Brazil. J. Med. Biol. Research., v. 34, p. 1531- 1538, 2001.

BUTLER, J.; HOEY, B.M.; SWALLOW, A.J. Radiation chemistry. Annu. Rep. Prog. Chem., v. 83, p. 129-175, 1987.

BUTLER, J.; LAND E.J.; SWALLOW A.J. Chemical mechanisms of the effects of high energy radiation on biological systems. Radiat. Phys. Chem., v. 24, p. 273-282, 1984.

CALMETTE, A. Les animaux nenimeux et la sérotherapie antivenimeuse. In: Les Venins. Masson et Cie, Paris, 1907.

CAMILLO, M.A.; ARRUDA PAES, P.C. TRONCONE, L.R.; ROGERO, J.R. gyroxin fails to modify in vitro release of labelled dopamine and acetylcholine from rat and mouse striatal tissue. Toxicon, v. 39(6), p. 843-853, 2001.

CAMPOS, L.A. Isolamento e caracterização da delta-toxina do veneno de Crotalus durissus terrificus. 2006. Dissertação (Mestrado) - Instituto de Pesquisas Energéticas e Nucleares, São Paulo.

CAPRONI, P.; BAPTISTA, J.A.; DE ALMEIDA, T.L.; PASSOS, L.A.C.; NASCIMENTO, N. Study of irradiated bothropstoxin-1 with ${ }^{60} \mathrm{Co}$ gamma rays: immune system behavior. J. Venom. Anim. Toxins incl. Trop. Dis. v. 15(2), p. 216-225, 2009.

CARDI, B.A.; NASCIMENTO, N.; ROGERO, J.R.; ANDRADE, H.F. Immunochemical detection of purified crotoxin from Crotalus durissus terrificus venom in motor end plate of striated muscle in CBA/J mice. Braz. J. Med. Biol. Res., v. 25, p. 905, 1992.

CARDOSO, J.L.C.; FRANCA, F.O.S.; WEN, F.H. Acidente botrópico. 2003. In: Animais peçonhentos no Brasil: biologia, clínica e terapêutica dos acidentes. França, F.O.S. \& Málaque, C.M.S. (Eds.). Editora Sarvier, São Paulo, p. 72-86.

CASARE, M.S. Estudo das interações dos produtos de radiólise da água com a miotoxina do veneo de Crotalus durissus terrificus. 2009. Tese (Doutorado) Instituto de Pesquisas Energéticas e Nucleares, São Paulo. 
CASARE, M.S. Influência das principais espécies reativas formadas durante o processo de destoxicação de toxinas por radiação ionizante. 2003. Dissertação (Mestrado) - Instituto de Pesquisas Energéticas e Nucleares, São Paulo.

CASARE, M.S.; SPENCER, P.J.; CAMPOS, L.A.; NASCIMENTO, N. Study of gammaradiation effects on crotamine and crotoxin. J. Radioanal. Nuc. Chem., v. 269(3), p. 571-577, 2006.

CHANG, C.C. \& TSENG, K.H. Effects of crotamine, a toxin of South American rattlesnake venom, on the sodium channel of murine skeletal muscle. $\mathbf{B r}$. J. Pharmacol., v. 63(3), p. 551-559, 1978.

CHAPLEAU, N.; MANGAVEL, C.; COMPOINT, J.P.; LAMBALLERIE, A.M. Effect of high-pressure processing on myofibrillar protein structure. J Sci Food Agric., v.84, p. 66-74, 2004.

CHEN, Y.; BARKLEY, M.D. Toward understanding tryptophan fluorescence in proteins. Biochem., v. 37(28), p. 9976-9982, 1998.

CHEYMOL, J.; GONÇALVES, J.M.; BOURILLET, F.; ROCH-ARVEILLER, M. Action neuromusculaire compare de la crotamine et du venin de Crotalus durissus terrificus var. Crotaminicus I. Sur preparations neurimusculaires in situ. Toxicon, v. 9, p. 279286, 1971.

CLISSA, P. B. Otimização da atenuação da toxicidade do veneno crotálico irradiado e estudo de suas propriedades imunológicas. 1997. Dissertação (Mestrado) - Instituto de Pesquisas Energéticas e Nucleares, São Paulo.

COCIANCICH, S.; BULET, P.; HETRU, C.; HOFFMANN, J.A. The inducible peptides of insects. Parasitol. Today, v. 10(4), p. 132-139, 1994.

COLLINS, C.H.; BRAGA, G.L.; BONATO, P.S. Fundamentos de Cromatografia. Campinas: Editora Unicamp, 2006.

CORONADO, M.A.; GABDULKHAKOV, A.; GEORGIEVA, D.; SANKARAN, B.; MURAKAMI, M.T.; ARNI, R.K.; BETZEL, C. Structure of the polypeptide crotamine from the Brazilian rattlesnake Crotalus durissus terrificus. Biological Crystallography., v. 69, p. 1958-1964, 2013.

DANIEL, J.P.; HENEINE, L.D.G.; TAVARES, C.A.P.; NASCIMENTO, M.C.S.; HENEINE, I.F. Generation of protective immune sera by C.d.terrificus venom detoxified by controlled iodination. Braz. J. Med. Biol. Res., v. 20, p. 713-720, 1987.

DIMARCQ, J.L,; BULET, P.; HETRU, C.; HOFFMANN, J. Cysteine-rich antimicrobial peptides in invertebrates. Biopolymers., v. 47(6), p. 465-477, 1998.

FADEL, V. Estrutura tridimensional da Crotamina extraída do veneno da cascavel Crotalus durissus terrificus utilizando ressonância magnética nuclear 
homonuclear. 2003. 107f. Dissertação de doutorado - Instituto de Biociências, Letras e Ciências Exatas, Universidade Estadual Paulista "Júlio de Mesquita Filho", São José do Rio Preto.

FADEL, V.; BETTENDORFF, P.; HERMANN, T.; AZEVEDO JR., W.F.; OLIVEIRA, E.B.; YAMANE, T.; WÜTHRICH, K. Automated NMR structure determination of the myotoxin crotamine from Crotalus durissus terrificus. Toxicon, v. 49, p. 759-767, 2005.

FAURE, G. \& BON, C. Crotoxin, a phospholipase A2 neurotoxin from the South American rattlesnake Crotalus durissus terrificus. Purification of several isoforms and comparision of their molecular structure and their biological activities. Biochem., v. 27, p. 730-738, 1988.

FERREIRA JÚNIOR, R.S.; NASCIMENTO, N.; COUTO, R.; ALVES, J.B.; MEIRA, D.A.; BARRAVIEIRA, B. Laboratory Evaluation of Young Ovines Inoculated with Natural or ${ }^{60} \mathrm{Co}$-Irradaited Crotalus durissus terrificus Venom During Hyperimmunization Process. J. Venom. Anim. Toxins incl. Trop. Dis. v. 12(4), p. 620-631, 2006.

FISHER, T.E.; OBERHAUSER, A.F.; CARRION-VASQUEZ, M.; MARSZALEK, P.E.; FERNANDEZ, J.M. The study of protein mechanics with the atomic force microscope. TIBS, p. 379-384, 1999.

FLOWERS, H.H. The effects of X-irradiation on the biological activity of cottonmouth moccasin (Ancistrodon piscivorus) venom. Toxicon, v. 1, p. 131-136, 1963.

FOGUEL, D. AND SILVA, J.L. New insights into the mechanisms of protein misfolding and aggregation in amyloidogenic diseases derived from pressure studies Biochemistry, v. 43, p. 11361-70, 2004.

FONSECA, L.C.; CORRÊA, N.C.R.; GARROTE-FILHO, M.S.; CUNHA, C.C.; PENHASILVA, N. Effects of the solvent composition on the stability of proteins in aqueous Solutions. Química Nova, v. 29, p. 543-548, 2006.

FOTIADIS, D.; SCHEURING, S.; MULLER, S.A.; ENGEL, A.; MULLER, D.J. Imaging and manipulation of biological structures with AFM. Micron, v. 33, p. 385-397, 2002.

GALAZKA, V.B.; DICKINSON, E.; LEDWARD, D.A. Effects of high pressure on the emulsifying behaviour of $\beta$-lactoglobulin. Food Hydrocollid., v. 10, p. 213-219, 1996.

GARRISON, W.M. Reaction mechanisms in the radiolysis of peptides, polypeptides, and proteins. Chem. Rev., v. 87, p. 381-398, 1987.

GONÇALVES, J.M. \& ARANTES, E.G. Estudos sobre venenos de serpentes brasileiras. III - Determinação quantitativa de crotamina no veneno de cascavel brasileira. An. Acad. Bras. Cienc., v. 28, p. 369-371, 1956.

GONÇALVES, J.M. \& VIEIRA, L.G. Estudos sobre venenos de serpentes brasileiras. I - Análise eletroforética. An. Acad. Bras. Cienc., v. 22, p. 141-149, 1950. 
GONÇALVES, J.M. Estudos sobre venenos de serpentes brasileiras. II - Crotalus terrificus crotsminicus, suespécie biológica. An. Acad. Bras. Cienc., v. 28, p. 365-367, 1956.

GROSH, D.S. \& HOOPYWOOD, L.E. Biological effects of radiation. $2^{\text {nd }}$ ed., Academic Press: New York, 1979.

GUARNIERI, M.C. Estudos dos efeitos da radiação gama de ${ }^{60} \mathrm{Co}$ nas propriedades bioquímicas, biológicas e imunológicas do veneno de Bothrops jararaca. 1992. Tese (Doutorado) - Instituto de Pesquisas Energéticas e Nucleares, São Paulo.

HAMPE, O.G.; VOZARI-HAMPE, M.M.; GONÇALVES, J.M. Crotamine conformation: effect of $\mathrm{pH}$ and temperature. Toxicon, v. 16, p. 453-460, 1978.

HANLEY, M.R. Conformation of the Neurotoxin Crotoxin Complex and Its Subunits. Biochemistry, v. 18(9), p. 1681-1688, 1979.

HATI, A.K.; HATI, R.N.; MANDAL, M.; PANDA, D.; DAS, S. The effect of gamma irradiated detoxified viper venom as a toxoid against viper venom. The Snake, v. 21, p. 36-40, 1989.

HAWKINS C.L.; DAVIES M.J. Generation and Propagation of Radical Reactions on Proteins. Biochim. Biophys. Acta, v. 1504(2-3), p. 196-219, 2001.

HERNANDEZ-OLIVEIRA, S.; TOYAMA, M.H.; TOYAMA, D.O.; MARANGONI, S.; HYSLOP, S.; RODRIGUES-SIMIONI, L. Biochemical, Pharmacological and Structural Characterization of a New PLA2 from Crotalus durissus terrificus (South American Rattlesnake) Venom. Protein J., v. 24(4), p. 233-242, 2005.

HONG, S.J. \& CHANG, C.C. Potentiation by crotamine of the depolarizing effects of batrachotoxin, protoveratrine $A$ and grayanotoxin I on the rat diaphragm. Toxicon. $v$. 21, p. 503-514, 1983.

HORTNAGEL, H. \& HANIN, J. Toxins affecting the cholinergic system. 1992. In. Selective neurotoxicity. Herken, H.; Hucho, F. (Eds.). Springer, Berlin Heldelberg New York, p. 293-332.

HOOVER, D.M.; WU, Z.; TUCKER, K.; LU, W.; LUBKOWSKI, J. Antimicrobial characterization of human beta-defensin 3 derivatives. Antimicrobial Agents and Chemotherapy, v. 47(9), p. 2804-2809, 2003.

KANKONKAR, S.R.; KANKONKAR, R.C.; GAITONDE, B.B.; GROSH, S.V. Irradiated cobra (Naja Naja) venom for biomedical applications. In: Radiosterilization of Medical Products. IAEA, 1975.

KAWANO, Y.; LAURE, C.J.; GIGLIO, J.R. Laser Raman study on crotamine. Biochem. Biophys. Acta, v. 705, p. 20-25, 1982. 
KELLY, S.M.; JESS, T.J.; PRICE, N.C. How to study proteins by circular dichroism. Biochimica et Biophysica Acta., v. 1751, p. 119-139, 2005.

KERKIS, I.; HAYASHI, M.A.F.; LIZIER, N.F. Pluripotent stem cells as an in vivo model of neuronal differentiation. Embryonic Stem Cell-Differentiation and Pluripotent Alternatives, Kallos, Ed., p. 81-89, InTech, Rijeka, Croatia, 2011.

KERKIS, I.; HAYASHI, M.A.F.; SILVA, A.R.B.P.; PEREIRA, A.; SÁ JÚNIOR, P.L.; ZAHARENKO, A.J.; RÁDIS-BAPTISTA, G.; KERKIS, A.; YAMANE, T. State of the Art in the Studies on Crotamine, a Cell Penetrating, Peptide from South American Rattlesnake. BioMed Research International. v. 2014, p. 1-9, 2014.

KIM, Y.; RANDOLPH, T.W.; SEEFELDT, M.B. AND CARPENTER, J.F. High-pressure studies on protein aggregates and amyloid fibrils. Meth. Enzymol., v. 413, p. 237-253, 2006.

LANSBURY, P.T. Evolution of amyloid: What normal protein folding may tell us about fibrillogenesis and disease. v. 96, p. 3342-4, 1999.

LAURE, C.J. Die Primar strutur des crotamins. Hope Seylers z. Physiol. Chem., v. 356, p. 213-215, 1975.

LEFEBVRE, B.G.; GAGE, M.J. AND ROBINSON, A.S. Maximizing recovery of native protein from aggregates by optimizing pressure treatment. Biotechnol. Progr. v. 20, p. 623-9, 2004.

LI, Y.; FORAN, P.; FAIRWEATHER, N.F.; PAIVA, A.; WELLER, U.; DOUGAN, G.; DOLLY, J.O. A single mutation in the recombinant light chain of tetanus toxin abolishes its proteolytic activity and removes the toxicity seen after reconstitution with native heavy chain. Biochemistry, v. 33, p. 7014-7020, 1994.

MANCIN, A C; SOARES, A M; ANDRIÃO-ESCARSO, S H; et al. The analgesic activity of crotamine, a neurotoxin from Crotalus durissus terrificus (South American rattlesnake) venom: a biochemical and pharmacological study. Toxicon, v. 36, n. 12, p. 1927-1937, 1998.

MANDAL, M.; HATI, R.N.; BARDHAN, D.K; HATI, A.K. Effect of gamma radiation on Cobre (Naja Naja) venom as a toxoid. The Snake, v. 23, p. 44-48, 1991.

MANDAL, M.; HATI, R.N.; HATI, A.K. Neutralization of pathophysiological manifestations of Russel's viper envenoming by antivenom raised against gammairradiated toxoid. Toxicon, v. 31, p. 213-216, 1993.

MICHAELS, H.B.; HUNT, J.W. A model for radiation damage in cells by direct effect and by indirect effect: a radiation chemistry approach. Radiat. Res., v. 74, p. 23-34, 1978. 
MINISTÉRIO DA SAÚDE. Estatística anual de casos de envenenamentos ofídicos. Disponível em: <http://portal.saude.gov.br/portal/saude/profissional>. Acesso em 05 mar. 2014.

MOON, S. \& SONG, K.B., Effect of $\gamma$-irradiation on the molecular properties of ovalbumin and ovomucoid and protection by ascorbic acid. Food Chemistry, v. 74, p. 479-483, 2001.

MURATA, Y. Efeitos da radiação gama no veneno de Crotalus durissus terrificus. 1988. Dissertação (Mestrado) - Instituto de Pesquisas Energéticas e Nucleares, São Paulo.

NASCIMENTO, F.D.; SANCEY, L.; PEREIRA, A.; ROME, C.; OLIVEIRA, V.; OLIVEIRA, E.B.; NADER, H.B.; YAMANE, T.; KERKIS, I.; TERSATIOL, I,L,S.; COLL, J.L.; HAYASHI, M.A.F. The Natural Cell-Penetrating Peptide Crotamine Targets Tumor Tissue in Vivo and Triggers a Lethal Calcium-Dependent Pathway in Culture Cells. Molecular Pharmaceutics, v. 9, p. 211-221, 2011.

NASCIMENTO, N. Caracterização bioquímica e imunológica dos principais produtos gerados pela irradiação de crotoxina. 1995. Tese (Doutorado) - Instituto de Pesquisas Energéticas e Nucleares, São Paulo.

NASCIMENTO, N. Estudo comparativo entre crotoxina nativa e irradiada. Aspectos bioquímicos e farmacológicos. 1991. Dissertação (Mestrado) - Instituto de Pesquisas Energéticas e Nucleares, São Paulo.

NASCIMENTO, N.; SEEBART, C.S.; FRANCIS, B.; ROGERO, J.R.; KAISER, I.I. Influence of ionizing radiation on crotoxin: biochemical and immunological aspects. Toxicon, v. 34(1), p. 123-131, 1996.

NICASTRO, G.; FRANZONI, L.; DE CHIARA, C.; MANCIN, A.C.; GIGLIO, J.R.; SPISNI, A. Solution structure of crotamine, a $\mathrm{Na}+$ channel affecting toxin of Crotalus durissus terrificus venom. Eur. J. Biochem., v. 270(9), p. 1969-1979, 2003.

OGUIURA, N. Caracterização do gene da crotamina nas variedades crotamina positiva e crotamina - negativa da cascavel Crotalus durissus terrificus. 1998. Tese (Doutorado) - Instituto de Biociências da Universidade de São Paulo, São Paulo.

OLIVEIRA, K.C. Aspectos estruturais de proteínas do veneno crotálico modificadas por radiação ionizante. 2010. Dissertação (Mestrado) - Instituto de Pesquisas Energéticas e Nucleares, São Paulo.

OUSSEDIK-OUMEHDI, H. \& LRABA-DJEBARI, F. Irradiated Cerastes cerastes Venom as a Novel Tool for Immunotherapy. Immunopharmacology and Immunotoxicology, v. 30, p. $37-52,2008$.

PALADINI, A.A.; WEBER, G. Pressure-induced reversible dissociation of enolase. Biochem. v. 20, p. 2587-93, 1981. 
PAPO, N. \& SHAI, Y. Host defense peptides as new weapons in cancer treatment. Cellular and Molecular Life Sciences, v. 62(7-8), p. 784-790, 2005.

PEIGNEUR, S.; ORTS, D.J.B.; SILVA, A.R.P.; OGUIURA, N.; BONI-MITAKE, M.; OLIVEIRA, E.B.; ZAHARENKO, A.J.; FREITAS, J.C.; TYTGAT, J. Crotamine Pharmacology Revisited: Novel Insights Based on the Inhibition of $\mathrm{K}_{v}$ Channels. Molecular Pharmacology. v. 82, p. 90-96, 2012.

PELLEGRINI FILHO, A.; VITAL-BRAZIL, O.; FONTANA, M.D.; LAURE, C.J. 1978. The action of crotaminie on skeletal muscle: an electrophysiological. In: Rosenberg, P. (Ed.), Toxins: Animal, Plants and Microbial. Pergamon Press, Oxford, pp. 375-382.

PELTRON, J.T. \& MCLEAN, L.R. Spectroscopic Methods for Analysis of Protein Secondary Structure. Anal. Biochem., v. 227, p. 167-176, 2000.

PEREIRA, A.; KERKIS, A.; HAYASHI, M.A.; PEREIRA, A.S.; SILVA, F.S.; OLIVEIRA, E.B.; PRIETO DA SILVA, A.R.; YAMANE, T., RÁDIS-BAPTISTA, G.; KERKIS, I. Crotamine toxicity and efficacy in mouse models of melanoma. Expert Opinion on Investigational Drugs, v. 20(9), p. 1189-1200, 2011.

PINHO, F.M.O.; PEREIRA, I.D. Ofidismo. Rev. Assoc. Med. Bras. [online]. v. 47(1), p. 24, 2001.

PHISALIX, L.D.; BERTRAND, G. Sur la propriété antitoxique du sang des animaux vaccinés contre le venin di vipère. C. R. Acad. Sci., v.118, p. 356-358, 1894.

PLUM, G.E. \& BRESLAUER, K.J. Calorimetry of proteins and nucleic acids. Curr. Opin. Struct. Biol., v. 5, p. 682-690, 1995.

PRADO-FRANCESCHI, J. Estudo sobre a convulxina. 1970. Dissertação (Mestrado) - Instituto de Biologia. Unicamp. Campinas, São Paulo.

PURANANANDA, C. Studies on effects of radiations on snake venoms with special aspects on the sterelization. Int. Atomic Energy Agency, Viena, 1972.

QIN, Z.; GUO, X.; LIN, Y.; CHEN, J.; LIAO, X.; HU, X.; WU, J. Effects of high hydrostatic pressure on physicochemical and functional properties of walnut (Juglans regia L.) protein isolate. J Sci Food Agric, v. 93(5), p. 1105-1111, 2012.

RANDOLPH, T.W.; SEEFELDT, M. AND CARPENTER, J.F. High hydrostatic pressure as a tool to study protein aggregation and amyloidosis Biochim. Biophys. Acta v. 1595, p. 224-34, 2002.

RIZZI, C.T.; CARVALHO-DE-SOUZA, J.L.; SCHIAVON, E.; CASSOLA, A.C.; WANKE, E.; TRONCONE, L.R. Crotamine inhibits preferentially fast-twitching muscles but is inactive on sodium channels. Toxicon, v. 50(4), p. 553-562, 2007. 
RODRIGUES, M.; SANTOS, A.; de la TORRE, B.G.; RÁDIS-BAPTISTA, G.; ANDREU, D.; SANTOS, N.C. Molecular characterization of the interaction of crotamine-derived nucleolar targeting peptides with lipid membranes. Biochimica and Biophysica Actano, v. 818(11), p. 2707-2717, 2012.

ROSENFELD, G. Ação neurotóxica de venenos ofídicos (Crotalus e Micrurus) no sistema nervoso central. Interpretação clínica. Ciênc. e Cul., v. 23, p. 1-45, 1971. Suplemento.

SCHENBERG, S. Geographical pattern of crotamine distribution in the same rattlesnake subspecies. Science, v. 129, p. 1361-1363, 1959.

SEEFELDT M.B., OUYANG J., FROLAND W.A., CARPENTER J.F., RANDOLPH T.W. High-pressure refolding of bikunin: Efficacy and thermodynamics. Protein Science., v. 13, p. 2639-2650, 2004.

SHORT, H.E.; MALLLICK, S.M.K. Detoxication of snake venoms by the photodynamic action of methylene blue. Indian J. Med. Res., v. 22, p. 529-536, 1935.

SILVA, C.A.; PORTARO, F.C.V.; FERNANDES, B.L.; IANZER, D.A.; GUERREIRO, J.R.; GOMES, C.L.; KONNO, K.; SERRANO, S.M.T.; NASCIMENTO, N.; CAMARGO, A.C.M. Tissue distribution in mice if BPP $10 \mathrm{c}$, a potent proline-rich anti-hypertensive peptide of Bothrops jararaca. Toxicon, v. 51, p. 515-523, 2007.

SILVA, J.L.; FOGUEL, D.; ROYER, C.A. Pressure provides new insights into protein refolding, dynamics and structure. Trends Biochem Sci. v. 26(10), p. 612-618, 2001.

SILVA, J.L. \& WEBER, G. Pressure stability of proteins. Annu Rev Phys Chem. v. 44, p. 89-113, 1993.

SILVA, S.H.O.; FERREIRA, S.R.; SILVA, T.A.A.R.; MOURA, P.R.; DAL-BELO, C.A.; SANCHEZ, E.F.; OLIVEIRA, C.R.B.; SIMIONI, L.R. Beneficial effects of crotamine in the treatment of myasthenic rats. Muscle \& Nerve, v. 47, p. 591-593, 2013.

SIQUEIRA, A.M.; MARTINS, N.F.; DE LIMA, M.E.; DINIZ, C.R.; CARTIER, A.; BROWN, D.; MAIGRET, B. A proposed 3D structure for crotamine based on homology building, molecular simulations and circular dichroism. J. Mol. Graph. Model., v. 20(5), p. 389-398, 2002.

SLOTTA C.H. \& FRAENKEL-CONRAT, M. Purificação e cristalização do veneno da cobra cascavel. Mem. Inst. Butantan, v. 12, p. 505-513, 1938.

SOUZA, C.F. Efeito de antidepressivos inibidores de recaptação neuronal de monoaminas sobre plasticidade adrenérgica do ducto deferente de rato. 2007. Tese (Doutorado) - Universidade Federal de São Paulo - Escola Paulista de Medicina, São Paulo. 
SPENCER, P.J. Alterações bioquímicas e imunológicas do veneno de Bothrops jararacussu irradiado com ${ }^{60}$ Co. 1995. Dissertação (Mestrado) - Instituto de Pesquisas Energética e Nucleares, São Paulo.

SPENCER, P.J. Efeitos da radiação na estrutura da Bothropstoxina-I. 1999. Tese (Doutorado) - Instituto de Pesquisas Energéticas e Nucleares, São Paulo.

ST. JOHN, R.J., CARPENTER, J.F. AND RANDOLPH, T.W. High-Pressure Refolding of Disulfide-Cross-Linked Lysozyme Aggregates: Thermodynamics and Optimization. Biotechnol. Prog. v.18, p.565-571, 2002.

ST. JOHN, R.J.; CARPENTER, J.F. AND RANDOLPH, T.W. High pressure fosters protein refolding from aggregates at high concentration. PNAS, v.96, p.13029-33, 1999.

ST. JOHN, R.J.; CARPENTER, J.F.; BALNY, C. AND RANDOLPH, T.W. High pressure refolding of recombinant human growth hormone from insoluble aggregates. J. Biol. Chem. v. 276, p.46856-63, 2001.

TAMBOURGI, D.V. Envenenamento por serpentes: doenças negligenciadas afetando países em desenvolvimento. Anais da $62^{\underline{a}}$ Reunião Anual da SBPC Natal, $\mathrm{RH}$, julho de 2010.

TEJASEN, P.; OTTOLENGHI, A. The effect of ultraviolet light on the toxicity and the enzymatic and antigenic activities of snake venom. Toxicon, v. 8, p. 225-233, 1970.

TOYAMA, M. H.; CARNEIRO, E. M.; MARANGONI, S.; BARBOSA, R. L.; CORSO, G.; BOSCHERO, A. C. Biochemical characterization of two crotamine isoforms isolated by a single step RP-HPLC from Crotalus durissus terrificus (South American rattlesnake) venom and their action on insulin secretion by pancreatic islets. Biochem. et Biophis. Acta, v. 1474, p. 56-60, 2000.

VITAL BRAZIL, O. \& EXCELL, B.J. Action of crotoxin and crotactin from the venom of Crotalus Durissus terrificus (South American rattlesnake) on the frog neuromuscular junction. J. Physiol., v. 212, p. 34-35, 1971.

VITAL BRAZIL, O. Contribuição ao estudo do veneno ophídico. I - Espécies venenosas brasileiras; mortalidade por mordedura de cobras. Rev. Med. Trop. São Paulo, v. 4, p. 255-260, 1901.

VITAL BRAZIL, O. Venenos ofídicos neurotóxicos. Rev. Ass. Med. Bras., v. 26, p. 212-218, 1980.

VITAL BRAZIL, O.; EUGÊNIO, A.G.B.; LASZLO, G.M. Origem da paralisia respiratória causada pela crotoxina. Ciênc. e Cult., v. 25, p. 1165-1169, 1973.

VITAL BRAZIL, O.; FRANCESCHI, J.P.; WAISBICH, E.P.Pharmacology of cristalline crotoxin. I. Toxicity. Mem. Inst. Butantan, v. 32, p. 973, 1966a. 
VITAL BRAZIL, O.; FRANCESCHI, J.P.; WAISBICH, E.P.Pharmacology of cristalline crotoxin. II. Neuromuscular blocking action. Mem. Inst. Butantan, v. 33, p. 991-992, 1966b.

VITAL BRAZIL, O.; PRADO-FRANCHESI, J.P.; LAURE, C.J. Repetitive muscle responses induced by crotamine. Toxicon, v. 17, p. 61-67, 1979.

VYAS, V.K,; BRAHMBHATT, K.; BHATT, H.; PARMAR, U. Therapeutic potential of snake venom in cancer therapy: current perspectives. Asian Pacific Journal of Tropical Biomedicine. v. 3(2), p. 156-162, 2013.

WALES, A. \& KUSEL, J.R. Biochemistry of irradiated Parasite vaccines: suggested models for their mode of action. Parasitol. Today, v. 8(11), p. 358-363, 1992.

YAMANE, E.S.; BIZERRA, F.C.; OLIVEIRA, E.B.; MOREIRA, J.T.; RAJABI, M.; NUNES, G.L.; SOUZA, A.O.; SILVA, I.D.; YAMANE, T.; KARPEL, R.L.; SILVA, P.I. Jr.; HAYASHI, M.A. Untraveling the antifungal activity of a South American rattlesnake toxin crotamine. Biochimie. v. 95(2), p. 231-240, 2013.

YOUNT, N.Y.; KUPFERWASSER, D.; SPISNI, A.; DUTZ, S.M.; RAMJAN, Z.H.; SHARMA, S.; WARING A.J.; YEAMAN, M.R. Selective reciprocity in antimicrobial activity versus cytotoxicity of hBD-2 and crotamine. Proc Natl Acad Sci USA. v. 106, p. 14972-14977, 2009. 
ANEXOS 
Anexo 2: Fotos do aparato de eletrofisiologia do Laboratório de Farmacologia Unidade Modo de Ação de Toxinas, do Instituto Butantan.

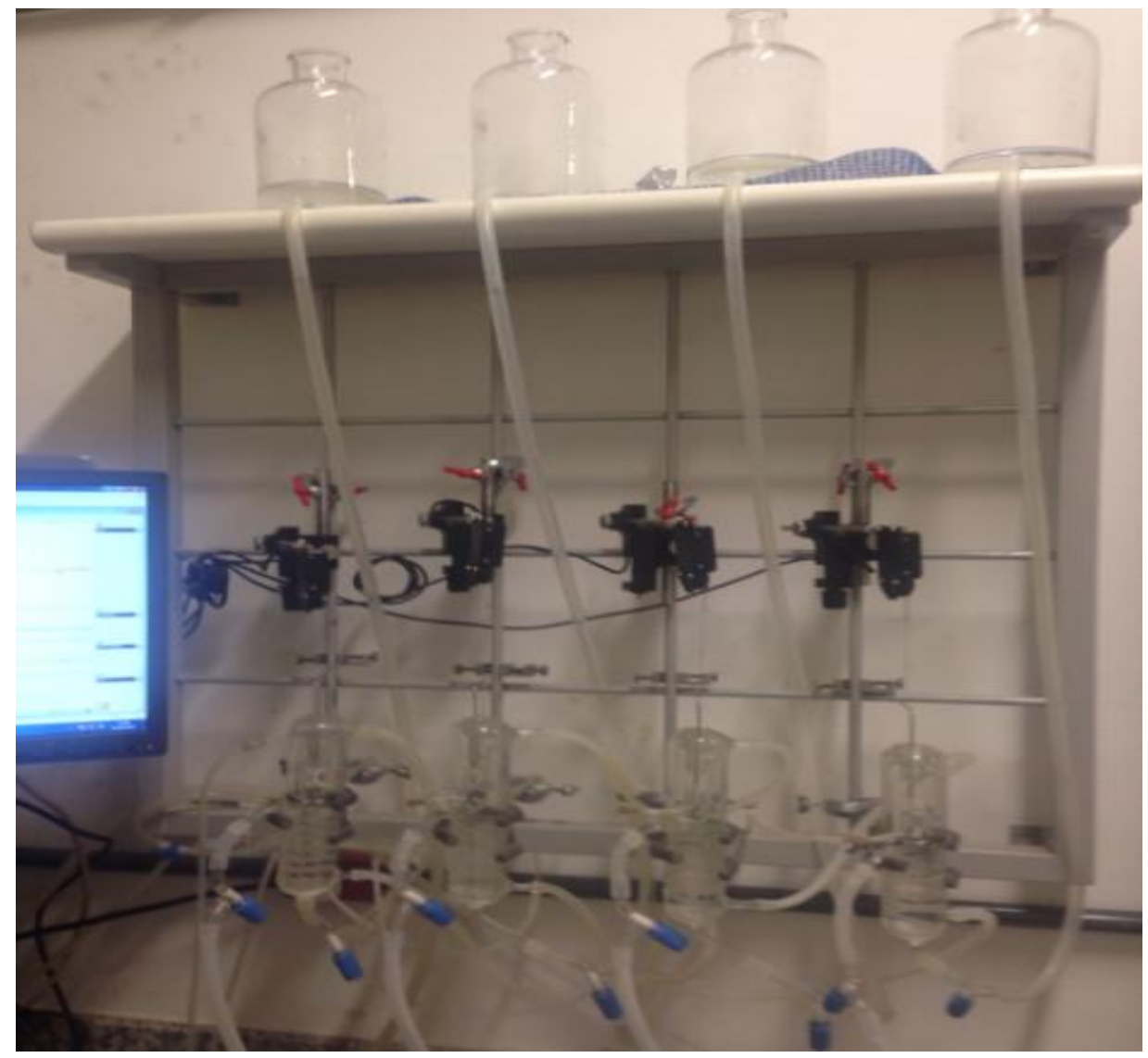

Cubas de vidro (câmara muscular) utilizadas para estímulo elétrico 


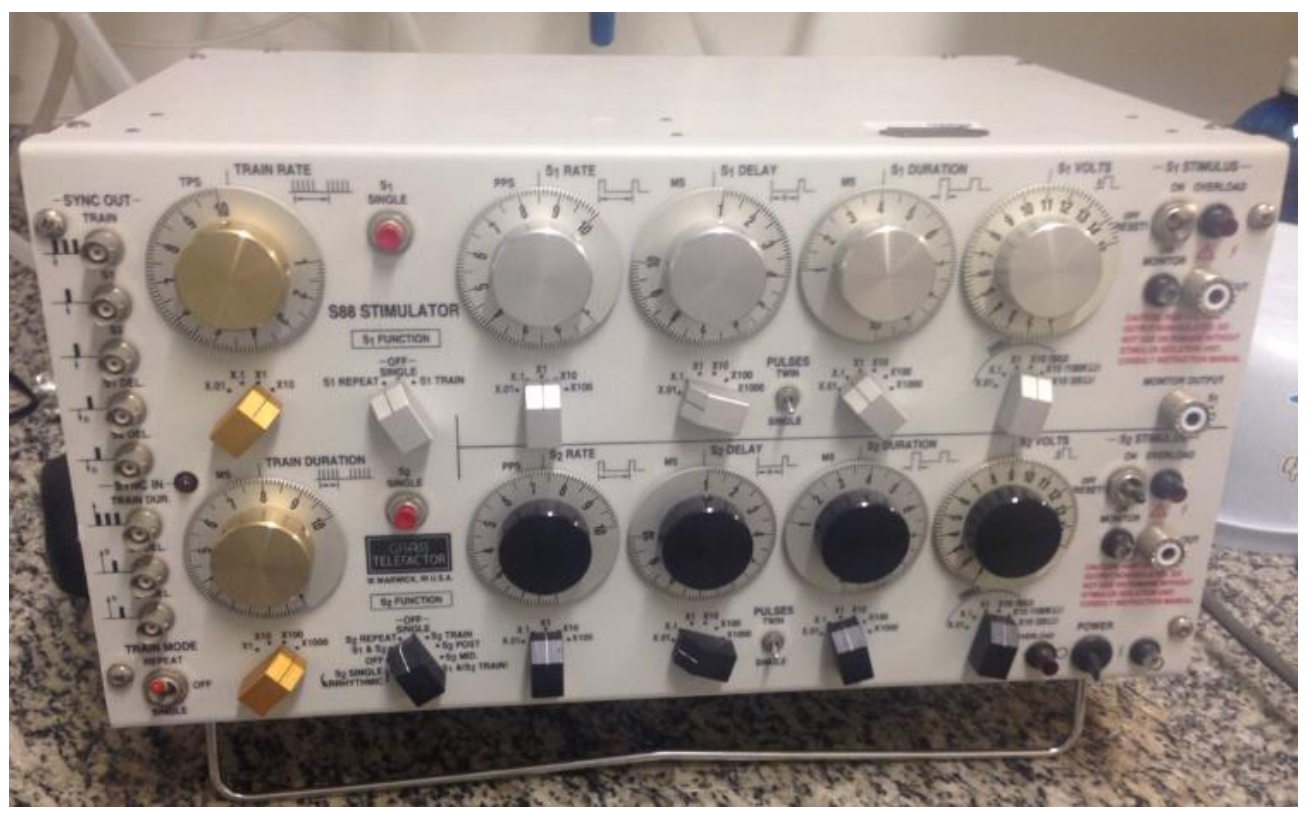

\section{Estimulador elétrico}

Anexo 3: Perfil cromatográfico do veneno total de C.d.t em coluna de exclusão molecular Superdex 75, tampão formiato de amônio, $50 \mathrm{mM}$, pH 3, obtido por Casare, 2003.

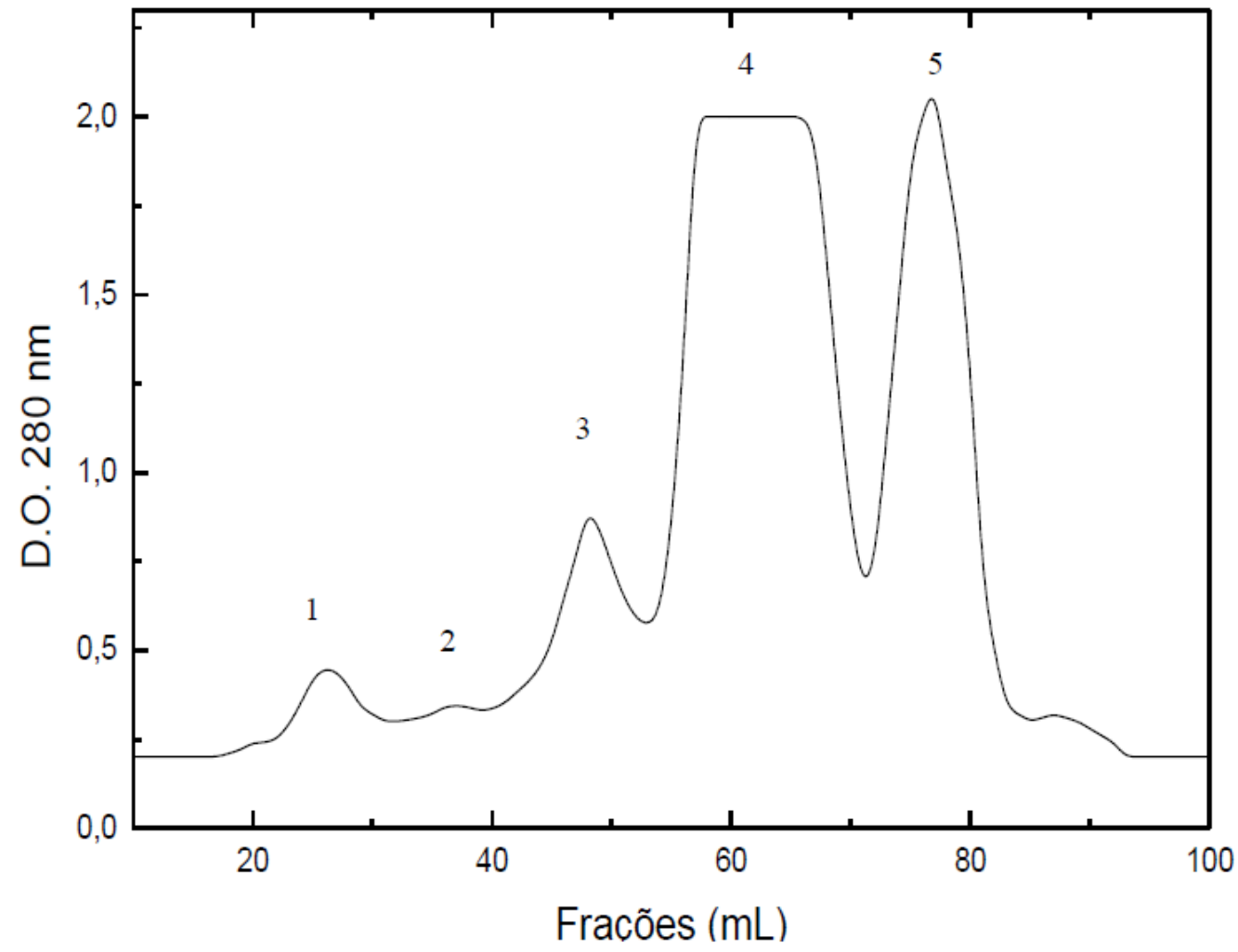

Anexo 4: Perfil cromatográfico do veneno total da C.d.t em coluna Superdex 75, tampão formiato de amônio, 100 mM, pH 3, obtido por Campos, 2006. 


$$
\mu
$$

